\title{
Mieke Koenen
}

INLEIDING TOT DE

LATIJNSE

SYNTAXIS

Structuur van zin en tekst

- Oefenboek —

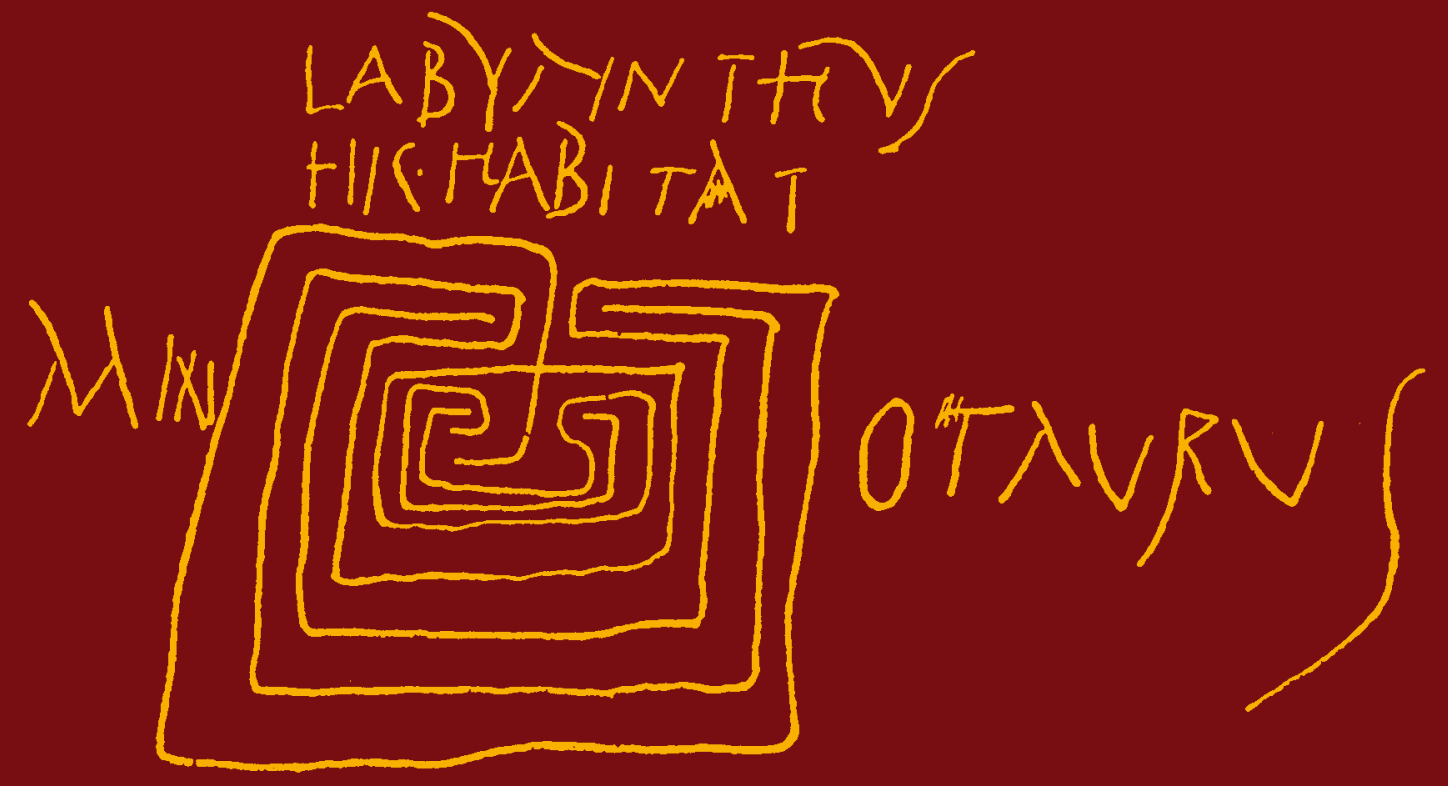


Inleiding tot de Latijnse Syntaxis Oefenboek 

Mieke Koenen

\section{Inleiding tot de Latijnse Syntaxis}

Oefenboek 
Dit oefenboek hoort bij het grammaticaboek Inleiding tot de Latijnse Syntaxis (Amsterdam University Press 2007, ISBN 978905356950 4)

Omslagillustratie: graffito uit Pompeii

Ontwerp omslag: Studio Jan de Boer, Amsterdam

Binnenwerk: PROgrafici, Goes

ISBN 9789053569511

NUR 616

(C) Amsterdam University Press, 2007

Alle rechten voorbehouden. Niets uit deze uitgave mag worden verveelvoudigd, opgeslagen in een geautomatiseerd gegevensbestand, of openbaar gemaakt, in enige vorm of op enige wijze, hetzij elektronisch, mechanisch, door fotokopieën, opnamen of enige andere manier, zonder voorafgaande schriftelijke toestemming van de uitgever.

Voor zover het maken van kopieën uit deze uitgave is toegestaan op grond van artikel 16B Auteurswet 1912 j $^{\circ}$ het Besluit van 20 juni 1974, Stb. 351, zoals gewijzigd bij het Besluit van 23 augustus 1985, Stb. 471 en artikel 17 Auteurswet 1912, dient men de daarvoor wettelijk verschuldigde vergoedingen te voldoen aan de Stichting Reprorecht (Postbus 3051, 2130 KB Hoofddorp). Voor het overnemen van gedeelte(n) uit deze uitgave in bloemlezingen, readers en andere compilatiewerken (artikel 16 Auteurswet 1912) dient men zich tot de uitgever te wenden. 


\section{Inhoudsopgave}

Achtergrond en integrale vertalingen $\quad 9$

Toelichting op Cicero's Pro Archia 9

Vertaling van Cicero's Pro Archia $\quad 10$

Toelichting op Livius' Coriolanus-verhaal 21

Vertaling van Livius' Coriolanus-verhaal 22

1 Grammaticale analyse $\quad 31$

2 Naamvallen $\quad 35$

3 Infinitivus $\quad 47$

4 Participium $\quad 55$

5 Gerundi(v)um $\quad 63$

$\begin{array}{lll}6 & \text { Tempus } & 67\end{array}$

$\begin{array}{lll}7 & \text { Modus } & 71\end{array}$

8 Vraagzinnen $\quad 81$

9 Oratio obliqua $\quad 83$

10 Tekstsamenhang $\quad 85$

$\begin{array}{ll}\text { Uitwerkingen } & 93\end{array}$

Overzicht van geciteerde auteurs en werken 125 



\section{Voorwoord}

Dit boek bestaat uit zinsoefeningen en tekstoefeningen bij elk hoofdstuk van Caroline Kroons Inleiding tot de Latijnse Syntaxis. Het materiaal is bedoeld als oefenstof voor wie zijn kennis en begrip van de syntaxis van het klassiek Latijn wil trainen en toetsen. Er wordt een ruime hoeveelheid gevarieerd materiaal aangeboden waaruit de gebruiker naar eigen inzicht en voorkeuren keuzes kan maken.

Het oefenboek is in eerste instantie bestemd voor studenten Klassieke Talen en Oudheidkunde in de bacheloropleiding. Zij kunnen de oefeningen individueel of in groepsverband maken, waarna hun uitwerkingen door de docent worden besproken. Maar het oefenboek kan ook dienen voor eenieder die zich de stof door zelfstudie eigen wil maken: achterin zijn beknopte uitwerkingen van alle opdrachten opgenomen. Zinnen en tekstoefeningen met een relatief hoge moeilijkheidsgraad zijn gemarkeerd met een asterisk.

Het overgrote deel van de zinnen uit de zinsoefeningen is afkomstig uit oorspronkelijke Latijnse teksten, proza en poëzie. De aaneengesloten fragmenten uit de tekstoefeningen stammen met name uit Cicero's Pro Archia, zijn pleitrede voor de dichter Archias, en uit Livius' verhaal over Coriolanus uit het tweede boek van zijn geschiedwerk $A b$ Urbe Condita. Deze teksten zijn, evenals Brief 7.27 van Plinius, Fabel 1.1 van Phaedrus en twee kortere fragmenten (respectievelijk Caesar BG 1.20 en Livius AUC 23.1), vertaald door Piet Schrijvers.

Om de instructie bij de tekstoefeningen zo beknopt mogelijk te houden is een inleidend hoofdstuk toegevoegd met korte toelichtingen op de Pro Archia en het Coriolanus-verhaal. Voor lezers die behoefte hebben aan meer context zijn hier ook de integrale vertalingen van deze beide teksten te vinden.

Een deel van dit oefenmateriaal kon worden vervaardigd dankzij een tijdelijke uitbreiding van mijn aanstelling aan de Faculteit der Letteren van de Vrije Universiteit Amsterdam.

Januari 2007

Mieke Koenen

Vrije Universiteit Amsterdam 



\section{Achtergrond en integrale vertalingen}

\section{Toelichting op Cicero's Pro Archia}

Aulus Licinius Archias, van Griekse komaf en geboren in Antiochië, was op jonge leeftijd al een beroemd dichter en voordrachtskunstenaar. Hij oogstte groot succes in Klein-Azië en Groot-Griekenland. In tal van steden verwierf hij (althans volgens Cicero, onze enige bron) het burgerrecht. In 102 voor Chr., toen hij zeventien jaar oud was, verhuisde hij naar Rome, dat in die tijd cultureel steeds belangrijker werd. Daar werd hij gastvrij ontvangen in de voornaamste kringen en door adoptie opgenomen in de invloedrijke familie van Lucius Licinius Lucullus. Tijdens een reis met zijn beschermheer door Zuid-Italië liet hij zich registreren als burger van de stad Heraclea. Dankzij de wet van M. Plautius Silvanus en C. Papirius Carbo (lex Plautia Papiria 89 voor Chr.) die het Romeinse burgerrecht toekende aan steden die Rome trouw waren gebleven in de Bondgenotenoorlog, verwierf Archias ook het Romeinse burgerrecht (civitas Romana).

In het jaar 62 werd Archias aangeklaagd door een zekere Grattius, die hem ervan beschuldigde dat hij zich ten onrechte Romeins burger noemde. Op basis van de wet van de volkstribuun C. Papius, die in 65 van kracht was geworden, kon iedere vreemdeling die op onrechtmatige wijze gebruikmaakte van het Romeinse burgerrecht worden verbannen. De dichter riep de hulp in van zijn vriend en oud-leerling Marcus Tullius Cicero (106-43) en stelde hem als beloning voor zijn verdiensten eeuwige roem in het vooruitzicht: een lofdicht op het consulaat dat Cicero het jaar daarvoor als eerste man uit zijn familie had bekleed.

Op de achtergrond van deze rechtszaak spelen politieke kwesties een rol. Zo is Cicero's vlammende redevoering niet verstoken van eigenbelang. Mede door de hardhandige en eigengereide manier waarop hij in het voorafgaande jaar een einde had gemaakt aan de samenzwering van Catilina, was zijn politieke invloed tanende. Ook had hij iets goed te maken bij Lucius Licinius Lucullus junior en bij Pompeius, die elkaars rivalen waren. 
Het is niet bekend of Archias werd vrijgesproken, maar men vermoedt van wel. Het beloofde gedicht over Cicero heeft hij niet geschreven. De redenaar heeft dit uiteindelijk zelf gedaan.

Cicero's Pro Archia is meer dan een verdedigingsrede: het werk laat zich ook lezen als een vurig pleidooi voor de letteren en culturele beschaving, voor de maatschappelijke en intrinsieke waarde van de humaniora.

\section{Vertaling van Cicero's pleitrede ter verdediging van de dichter Archias}

(1) Heren juryleden, als er in mij enig talent steekt - ik besef hoe gering het is - of enige spreekervaring - ik ontken niet een bescheiden ervaring te bezitten - of enig intellectueel en oratorisch inzicht, vrucht van studie en onderricht op het gebied van de hoogste kunsten en wetenschappen - ik beken dat ik geen moment van mijn leven hiervan afkerig ben geweest -, dan mag voor al deze verworvenheden mijn cliënt Aulus Licinius beslist als eerste bijna rechtmatig een beloning van mij terugvorderen. Want voor zover ik in mijn geest over het tijdperk van het verleden kan terugblikken en de diepste herinnering aan mijn vroegste jeugd kan terugroepen, van het verste punt teruggaand tot de dag van vandaag, zie ik hoe hij voor mij zich de leidsman betoond heeft om de weg van deze studie te betreden en aan te vangen. Indien echter onze stem, door zijn aansporingen en voorschriften gevormd, ooit aan enig mens bescherming heeft geboden, dan moeten wij zeker aan deze man, van wie wij datgene hebben ontvangen waarmee wij anderen kunnen helpen en redden, hulp en bijstand bieden voor zover dit in ons vermogen ligt.

(2) Laat niemand zich over onze woorden verbazen omdat mijn cliënt een duidelijk andere bekwaamheid bezit dan methodische scholing in de welsprekendheid: wij zijn nooit louter dit ene specialisme volledig toegedaan geweest. Alle kunsten en wetenschappen die tot de menselijke beschaving bijdragen, bezitten een gemeenschappelijke band en worden als het ware door onderlinge verwantschap verbonden.

(3) Maar opdat niemand van $u$ zich erover verbaast dat ik bij een justitieel onderzoek in een openbaar gerechtshof, bij een proces dat ten overstaan van de edelachtbare praetor van het Romeinse volk, voor zeer gestrenge juryleden en onder grote belangstelling van het samengestroomde publiek wordt gevoerd, een spreektrant bezig die niet alleen indruist tegen de juridi- 
sche praktijk maar ook tegen het reguliere taalgebruik, vraag ik $\mathrm{u}$ om in dit proces mij toestemming te verlenen - die in overeenstemming is met de status van de beklaagde en die $\mathrm{u}$ hopelijk niet zult betreuren - dat ik, nu ik voor een beroemd dichter en geleerde een pleidooi houd en gezien de toeloop van het zeer literair gevormde publiek, gezien uw eigen opleidingsniveau en gezien het feit dat deze praetor president van de rechtbank is, met uw permissie over het onderwerp 'beschaving en literaire vorming' iets openhartiger spreek en in het bijzijn van een persoon die door zijn teruggetrokken studieuze leven nooit in riskante processen verwikkeld is geraakt, een in bepaald opzicht nieuwe en ongebruikelijke stijl hanteer.

(4) Als ik zal bemerken dat dit door u wordt toegestaan en toegekend, zal ik ongetwijfeld bewerkstelligen dat $\mathrm{u}$ ervan overtuigd zult zijn dat mijn cliënt Aulus Licinius niet alleen niet uit het getal der burgers moet worden verwijderd - want hij is burger - maar dat hij, ook als hij geen burger zou zijn, als zodanig zou moeten worden toegelaten. Want zodra Archias de kinderschoenen ontgroeid was en na het onderwijs waardoor het kind tot een niveau van algemene beschaving pleegt te worden gevormd, een loopbaan als schrijver nastreefde, slaagde hij er in allereerst te Antiochië - daar is hij geboren uit voorname familie -, een drukbevolkte en welvarende stad met een hoog ontwikkelde bevolking en een zeer rijk cultuurleven, snel door zijn roemvol talent boven allen uit te blinken. Later werd in de rest van Klein-Azië en in heel Griekenland zijn optreden dermate bejubeld dat de reputatie van zijn talent door de verwachtingen en de verwachtingen door zijn persoonlijk optreden en de bewondering werden overtroffen.

(5) Heel Italië was toen vervuld van Griekse kunsten en wetenschappen en deze geestelijke bezigheden werden toen ook in Latium met grotere ijver beoefend dan nu in dezelfde steden het geval is, en hier in Rome werden zij dankzij de rustige politieke toestand niet verwaarloosd. De inwoners van Tarentum, Locri, Regium en Napels hebben hem het burgerschap en andere onderscheidingen verleend en allen die tot enig oordeel over getalenteerdheid in staat waren, achtten hem hun kennismaking en gastvrijheid waardig. Door zo'n roemvolle reputatie ook al bekend bij wie hem niet hadden gezien, arriveerde hij in Rome tijdens het consulaat van Marius en Catulus. Hij trof er allereerst consuls aan van wie de een zeer grote daden als stof tot schrijven kon bieden, de ander daden alsmede een belangstellend oor. De Luculli hebben Archias terstond in hun 
huis opgenomen, ook al droeg hij toen nog de kindertoga, maar het is een teken niet alleen van zijn literair talent maar ook van zijn moreel hoogstaand karakter dat dit eerste huis van zijn jeugd hem ook aan het eind van zijn leven zeer toegenegen is geweest.

(6) In die tijd was hij geliefd bij de beroemde Quintus Metellus Numidicus en diens zoon Pius, hij trad op voor Marcus Aemilius, hij was bevriend met vader en zoon Quintus Catulus, hij werd gewaardeerd door Lucius Crassus. Toen hij de Luculli, Drusus, de Octavii, Cato en de gehele familie van de Hortensii in vertrouwelijke omgang aan zich verbonden hield, verwierf hij het hoogste aanzien, omdat hij niet alleen werd gerespecteerd door degenen die iets wilden leren en horen, maar ook door degenen die dit louter simuleerden. Toen hij in die jaren na verloop van enige tijd met Marcus Lucullus naar Sicilië was vertrokken en met Lucullus weer uit die provincie terugkeerde, arriveerde hij in Heraclea. Omdat deze stad krachtens verdrag gelijkgerechtigd was, wilde hij zich daar als burger laten inschrijven en omdat hij persoonlijk daartoe waardig geacht werd, alsmede dankzij het gezag en de invloed van Lucullus, heeft hij dit bij de burgers van Heraclea gedaan gekregen.

(7) Het burgerrecht is hem verleend krachtens de wet voorgesteld door Silvanus en Carbo: 'alwie bij verbonden steden is ingeschreven en bij uitvaardiging van deze wet in Italië zijn domicilie heeft en binnen zestig dagen zich bij de praetor als zodanig heeft aangemeld.' Aangezien hij al vele jaren zijn domicilie in Rome had, heeft hij zich aangemeld bij de praetor Gaius Metellus, een persoonlijke relatie van hem.

(8) Als wij alleen over wettig burgerrecht te spreken hebben, hoef ik verder niets meer te zeggen: mijn verdedigingsrede is dan afgelopen. Welk onderdeel van de inhoud kan ontkracht worden, Grattius? Wilt u ontkennen dat hij toen in Heraclea is ingeschreven? Als getuige is aanwezig een man met zeer groot gezag, oprecht en betrouwbaar, Marcus Lucullus, die zegt dat hij dit niet meent maar weet, niet gehoord maar gezien heeft, niet erbij geweest is maar het heeft doorgevoerd. Als getuigen zijn aanwezig vertegenwoordigers uit Heraclea, mensen van zeer hoge komaf, omwille van dit proces met volmachten en met een officieel getuigenis gekomen, die verklaren dat hij als burger van Heraclea staat ingeschreven. U mist de officiële bevolkingsregisters van Heraclea, die - zoals wij allen weten tijdens de Italische oorlog bij een brand in het archief verloren 
zijn gegaan? Het is lachwekkend om op wat wij zien niets terug te zeggen maar te vragen wat wij niet kunnen hebben, over de menselijke herinnering te zwijgen maar een geschreven herinnering te vorderen en terwijl $u$ het gewetensvol getuigenis van een zeer hooggeacht man en de beëdigde verklaring van een integere gemeenschap bezit, datgene wat op geen enkele manier vervalst kan worden, af te wijzen en te vragen om registers die naar uw eigen zeggen vervalst plegen te worden.

(9) Heeft hij soms geen domicilie in Rome gehad, een man die zovele jaren vóór de verlening van het burgerrecht Rome als vestigingsplaats heeft verkozen van al zijn have en goed? Heeft hij zich soms niet aangemeld? Integendeel, hij staat aangemeld in de registers die als enige op het punt van aanmelding bij het praetorencollege het gezag van officiële registers bezitten. Want toen, naar verluidt, de registers van Appius ietwat al te slordig waren bijgehouden en de nonchalance van Gabinius - zolang zijn positie nog onaangetast was - en het échec na zijn veroordeling iedere betrouwbaarheid van de registers hadden vernietigd, is Metellus, een zeer scrupuleus en gewetensvol man, zo nauwgezet geweest dat hij zich bij de praetor Lucius Lucullus en de rechtbank vervoegd heeft en zijn verontrusting heeft uitgesproken over het doorgeschrapt zijn van één naam. Welnu, in deze registers vindt $u$ de naam van Aulus Licinius niet doorgeschrapt!

(10) Waarom heeft $u$, gezien deze stand van zaken, dan twijfels over zijn burgerrecht, wanneer hij bovendien ook nog in andere steden is ingeschreven geweest? Terwijl men immers in Groot-Griekenland aan vele mensen van laag allooi, zonder beroep of met een vulgair beroep, zonder probleem het burgerrecht placht te verlenen, moet ik geloven dat de inwoners van Regium, Locri, Napels of Tarentum datgene wat zij voortdurend gul aan toneelspelers uitdeelden, aan mijn beroemde en getalenteerde cliënt zouden hebben geweigerd? Verder, terwijl zovelen niet alleen na de verlening van het burgerrecht maar ook na de uitvaardiging van de wet van Papius op een of andere manier de registers van die steden zijn binnengekropen, zal mijn cliënt, die zich zelfs niet op die registers beroept waar hij daadwerkelijk staat ingeschreven, omdat hij altijd inwoner van Heraclea heeft willen zijn, worden afgewezen?

(11) U mist hem op de censuslijsten. Natuurlijk: het is niet bekend dat mijn cliënt tijdens het laatste censorschap met de zeer beroemde generaal Lucius Lucullus in het leger is geweest, bij 
het een na laatste tijdens het quaestoraat van Lucullus in KleinAzië verbleef, bij het eerste (gedurende het consulaat van Julius en Crassus) geen volkstelling heeft plaatsgevonden. Maar aangezien de censuslijst niet het burgerrecht bekrachtigt en alleen uitsluitsel geeft dat degene die op de lijst staat, zich toen als burger heeft beschouwd - in die jaren heeft de man die $\mathrm{u}$ ervan beschuldigt dat hij naar eigen oordeel buiten het Romeinse burgerrecht zou vallen, dikwijls een wettig testament opgesteld, is hij in de testamenten van Romeinse burgers opgenomen en voor toelagen naar de staatskas verwezen door de proconsul Lucius Lucullus. Zoekt u maar bewijsgronden als u kunt! Nooit zal mijn cliënt door eigen oordeel of door het oordeel van zijn vrienden schuldig worden verklaard.

(12) U zult ons nu wel vragen, Grattius, waarom wij zozeer aan deze man gehecht zijn? Omdat hij ons de ruimte biedt waar wij geestelijk kunnen bijkomen van dit rumoer op het Forum en onze oren doodmoe van dit gekrakeel kunnen uitrusten. Of denkt u soms dat het voor ons toereikend kan zijn om dagelijks bij zovele verschillende aangelegenheden het woord te voeren als wij ons geestelijk niet door studie vormen, of zo'n grote mentale inspanning kunnen verdragen als wij ons niet door diezelfde studie ontspannen? Ik geef toe dat ik aan deze studies verknocht ben. Anderen moeten zich schamen als zij zich zozeer in de boeken hebben begraven dat zij daaruit niets kunnen bijdragen tot nut van het algemeen of ervan zichtbaar kunnen maken; waarom zou ik mij moeten schamen, heren juryleden, ik die zovele jaren mijn leven zo inricht dat op geen enkel belangrijk moment ik van mijn medemensen ben weggehouden door mijn studie, weggeroepen door mijn belangstellingen of door mijn slaap te laat ben gekomen.

(13) Wie zou mij daarom kunnen bekritiseren of op goede gronden mij een verwijt kunnen maken als ik de tijd die aan anderen wordt gegund om hun privézaken te behartigen, om feesten te vieren en spelen te bezoeken, voor andere genoegens en in het bijzonder voor geestelijke en lichamelijke ontspanning, de tijd die anderen besteden aan vroeg beginnende schranspartijen, aan gokken en sport, voor mijzelf reserveer om te kunnen studeren? En des te meer moet men mij dit vergunnen omdat deze studie ook tot resultaat leidt: mijn spreekvaardigheid die - van welk niveau zij ook moge zijn - zich nooit aan de gevaren van mijn vrienden heeft onttrokken, en als iemand die vaardigheid onbelangrijk acht: dat wat in elk geval het belangrijkste is, ik weet uit welke bron ik het put. 
(14) Want als ik niet van jongs af aan dankzij de vele voorschriften van vele schrijvers mij de overtuiging had eigen gemaakt dat er geen hoger levensdoel bestaat dan eer en roem, en dat bij het nastreven ervan iedere lichamelijke kwelling, ieder gevaar van dood en verbanning moeten worden geminacht, dan zou ik mij nooit voor uw welzijn in zovele hevige conflicten hebben gestort en deze dagelijkse aanvallen van verdorven figuren hebben getrotseerd. Maar alle boeken staan er vol van, alle woorden van filosofen staan er vol van, van de historische voorbeelden die alle in duisternis verwaarloosd zouden liggen als het schijnsel van de literatuur hen niet zou verlichten. Talrijk zijn de beeltenissen van de dapperste mannen die de Griekse en Latijnse schrijvers ons hebben nagelaten, niet alleen ter aanschouwing maar ook ter navolging. Hen hield ik altijd voor ogen tijdens mijn maatschappelijke loopbaan en ik vormde aldus mijn hart en verstand juist door het denken aan deze voortreffelijke mensen.

(15) Iemand zal nu verwonderd vragen: die voortreffelijke mannen, wier kwaliteiten in geschriften zijn overgeleverd, zijn die zelf gevormd door de studie die $\mathrm{u}$ zo ophemelt? Het is moeilijk om ten aanzien van allen deze vraag bevestigend te beantwoorden, maar het antwoord dat ik kan geven, staat buiten kijf. Ik geef toe dat er vele voortreffelijke, hoogstaande mensen zijn geweest die, zonder scholing, dankzij een bijna goddelijk te noemen aanleg op eigen kracht belangrijke persoonlijkheden van niveau zijn geworden. En ik voeg er nog het volgende aan toe: aanleg zonder scholing heeft vaker tot roemvolle prestaties geleid dan scholing zonder aanleg. Maar mijn stelling is ook: wanneer aan een bijzondere en schitterende aanleg ook een meer methodische scholing is gekoppeld, dan pleegt er iets heel prachtigs en bijzonders te ontstaan.

(16) Tot die laatste categorie behoorde degene die onze vaders nog hebben gekend, een goddelijk man, Africanus, tot die categorie behoorden Gaius Laelius, Lucius Furius, moreel hoogstaande en karaktervolle mensen, tot die categorie behoorde een zeer daadkrachtig man, de geleerdste van zijn tijd: Marcus Porcius Cato de Oude. Als zij zich niet door hun studies gesteund voelden om dit hoogste niveau te bereiken en te behouden, zouden zij zich nooit en te nimmer eraan hebben gewijd. Ook als dit grote voordeel zich niet zou voordoen en er alleen maar genoegen in deze intellectuele studies werd gezocht, zou u - denk ik - deze geestelijke bezigheid toch zeer menswaardig en beschavend achten. Alle andere bezigheden passen niet bij alle 
tijden, bij alle leeftijden of gelegenheden, maar deze intellectuele vorming spoort de jongeren aan, verblijdt de ouderen, verfraait de voorspoed, biedt toevlucht en steun in tegenspoed, zij is een bron van vreugde in huis, geen hindernis buitenshuis, zij vergezelt ons, 's nachts, in den vreemde, op het land.

(17) Ook als wij zelf niet in deze vorming konden delen en de smaak ervan niet konden proeven, zouden wij haar toch moeten bewonderen ook als wij haar slechts in anderen aanwezig zagen. Wie van ons was zo onbeschaafd en afgestompt dat hij onlangs niet door de dood van Roscius werd ontroerd, een man die, hoewel op hoge leeftijd gestorven, omwille van zijn uitnemende bekwaamheid en charme nooit had mogen sterven. Door de beweging van zijn lichaam had hij zo'n grote geliefdheid bij ons allen verworven: zullen wij dan de wonderbaarlijke beweeglijkheid van de geest en de snelheid van het menselijk denken minachten?

(18) Dikwijls heb ik Archias gezien, heren juryleden - ik maak van uw instemming gebruik omdat $\mathrm{u}$ zo aandachtig naar mij luistert bij dit ongebruikelijke pleidooi -, dikwijls heb ik gezien hoe Archias, ook al had hij geen woord opgeschreven, een groot aantal prachtige verzen over actuele gebeurtenissen improviseerde, hoe hij, teruggeroepen, hetzelfde onderwerp bezong met andere woorden en denkbeelden. Wat hij echter met veel zorg en voorbereiding had neergeschreven, vond - naar ik zag - zoveel erkenning dat hij de roem van de klassieke schrijvers evenaarde. Moet ik deze man dan niet beminnen, bewonderen, het niet tot mijn plicht achten hem hoe dan ook te verdedigen? Wij hebben van beroemde en geleerde mensen geleerd: alle andere beroepsvaardigheden berusten op scholing, regels, techniek, alleen de dichter put zijn vermogen uit natuurlijke aanleg, wordt door innerlijke krachten aangevuurd en door een goddelijk te noemen bezieling geïnspireerd. Terecht worden dichters door onze beroemde Ennius 'heilig' genoemd omdat zij ons als een dierbare gave der goden zijn geschonken.

(19) Laat daarom, heren juryleden, bij u - beschaafde mensen - de naam van dichter heilig zijn, een naam die door geen enkel barbarenland ooit is geschonden! Rotsen, eenzame streken antwoorden op hun stem, wilde dieren worden vaak door hun gezang getemd en tot staan gebracht, moeten wij, die door de hoogste beschaving zijn gevormd, dan niet worden ontroerd door het dichterwoord? Bewoners van Colophon beweren dat Homerus hun burger is, Chioten eisen hem op als hun Chioot, Salaminiërs claimen hem, inwoners van Smyrna verzekeren 
dat hij echt van hen is en hebben daarom ook een heiligdom ter zijner ere in hun stad opgericht en nog vele anderen betwisten hem. Anderen claimen dus een vreemdeling, zelfs nog na zijn dood, omdat hij een dichter was; moeten wij hem hier dan afwijzen, die in leven is en naar eigen verlangen en op grond van de wet bij ons behoort, terwijl, let wel, Archias sinds lange tijd al zijn werkkracht en al zijn talent in dienst heeft gesteld van de verheerlijking van de roem en de glorie van het Romeinse volk? De Cimbrische oorlogen, daar is hij in zijn jeugd aan begonnen, en hij was geliefd zelfs bij Gaius Marius, die voor dergelijke literaire activiteiten geen al te grote sympathie leek te bezitten.

(20) Maar niemand is zo afkerig van de Muzen dat hij de onvergankelijke lofzang op zijn daden niet aan de dichtkunst wil toevertrouwen. Men vertelt dat toen Themistocles, de belangrijkste man in Athene, werd gevraagd welke voordracht en welke stem hij het liefste hoorde, hij als antwoord gaf: 'de stem van diegene door wie mijn prestaties het beste worden geprezen.' Daarom was ook die beroemde Marius een groot liefhebber van Lucius Plotius door wiens talent zijn verrichtingen volgens hem konden worden verheerlijkt.

(21) De Mithridatische oorlog, een grote en zware oorlog die zich in bonte afwisseling te land en ter zee heeft afgespeeld, is in haar geheel door Lucius Plotius onder woorden gebracht. Deze geschriften stellen niet alleen Lucius Lucullus, een heldhaftig en vermaard man, maar ook de naam van het Romeinse volk in een roemvol licht. Het Romeinse volk heeft onder het bevel van Lucullus het Pontische land opengelegd, dat voordien door koninklijke macht en de natuurlijke gesteldheid was omschanst. Het leger van het Romeinse volk heeft onder dezelfde aanvoerder met een niet omvangrijke legermacht talloze troepen van de Armeniërs verslagen. Het siert het Romeinse volk dat het de bevriende stad Cyzicus op aandrang van dezelfde generaal bij iedere aanval van de koning uit het verslindende, monsterlijke oorlogsgeweld heeft gered en beschermd. Altijd zal als onze prestatie worden vermeld en verkondigd hoe door de beslissende strijd van Lucius Lucullus de vijandige vloot is vernietigd, de aanvoerders zijn gedood: de wonderbaarlijke zeeslag bij Tenedos. Aan ons zijn de zegepralen, aan ons de eretekenen, aan ons de triomfen! Door de poëtische talenten wordt dit alles verkondigd, door hen wordt de roem van het Romeinse volk verbreid. 
(22) Dierbaar aan de oudere Scipio was onze Ennius: daarom werd - naar men denkt - zijn marmerportret in het Scipionengraf bijgezet. Maar door dergelijke lofzangen wordt zeker niet alleen de geprezen persoon, maar ook de naam van het Romeinse volk geëerd. De voorouder van onze Cato wordt hemelhoog geprezen, de hoge eer aan de geschiedenis van het Romeinse volk gekoppeld. Kortom, al die grote mannen als Maximus, Marcellus, Fulvius worden niet geëerd zonder een collectieve lofprijzing van ons allen. De dichter die dit had bewerkt, een man uit Rudiae, hebben onze voorouders in de burgerij opgenomen: zullen wij deze burger uit Heraclea, die door vele steden als burger werd gewenst, in onze stad tot wettig burger werd verklaard, uit onze burgerij verwijderen?

(23) Als iemand denkt dat Griekse verzen een geringer voordeel van naambekendheid verschaffen dan Latijnse, dan vergist hij zich deerlijk, want Grieks wordt bijna overal gelezen terwijl Latijn beperkt blijft tot zijn eigen, betrekkelijk smalle grondgebied. Daarom moeten wij, zo waar de successen die wij hebben behaald hun effecten over de hele aarde bezitten, verlangen dat onze naam en faam even ver doordringen als de lansen uit onze handen gevlogen zijn, omdat dit belangrijk is niet alleen voor de volkeren zelf wier prestaties worden beschreven, maar vooral omdat dit voor diegenen die omwille van de roem op leven en dood strijden de grootste aansporing is om gevaren en ontberingen te doorstaan.

(24) Talrijk zijn de schrijvers van zijn eigen geschiedenis geweest die Alexander de Grote om zich heen zou hebben gehad! Maar toch, toen hij in Sigeum bij het graf van Achilles was aangekomen, riep hij uit: 'O, gelukkige jongen, jij hebt Homerus gekregen als heraut van jouw heldendom!' Want als voor hem die dichtkunst niet zou hebben bestaan, zou het graf dat zijn lichaam bedekt ook zijn naam hebben bedolven. En verder heeft onze grote Pompeius, wiens succes gelijk was aan zijn dapperheid, niet Theophanes uit Mytilene, de kroniekschrijver van zijn daden, in de soldatenvergadering het burgerschap verleend en hebben onze dappere mannen - maar toch boeren en soldaten - door de zoetheid van de roem vervuld dit niet onder luid geschreeuw goedgekeurd alsof zij deelden in diezelfde roem?

(25) Als Archias niet al een wettig burger was, kon hij er dan niet in slagen dat hem door een legeraanvoerder het burgerschap werd verleend? Moet ik dat geloven? Toen Sulla de Spanjaarden en de Galliërs tot burgers verklaarde, zou hij mijn cliënt 
ondanks diens verzoek hebben afgewezen? Moet ik dat geloven? Wij hebben gezien hoe Sulla in de volksvergadering, toen een pruldichter uit het volk hem een papyrusrol had overhandigd omdat hij op hem een epigram had gemaakt in disticha die alleen een beetje te lang waren uitgevallen, terstond uit de opbrengst van wat hij toen aan het verkopen was een beloning liet uitbetalen op die voorwaarde dat hij in de toekomst nooit meer zou schrijven. Iemand die de vlijt van een pruldichter toch een beloning waard vond, zou niet het schrijftalent van mijn cliënt, zijn bekwaamheid en verbaal vermogen, willen winnen?

(26) En verder, Quintus Metellus Pius, een zeer vertrouwde relatie, die aan velen het burgerrecht had geschonken, iemand die bovendien zozeer wenste dat zijn prestaties in geschriften werden vereeuwigd dat hij zelfs naar dichters uit Corduba luisterde die toch een beetje gezwollen en vreemd klonken, van hem zou Archias dit niet op eigen initiatief of via de Luculli hebben gekregen? Men moet niet ontkennen wat niet verborgen kan worden, nee, wij moeten openlijk toegeven: wij worden allemaal door verlangen naar roem meegesleept en hoe bekwamer de mens des te groter zijn eerzucht. Zelfs de filosofen die over de verachting van de roem schrijven zetten hun naam op het titelblad: juist daar waar zij lofprijzing en beroemdheid verachten, willen zij genoemd en geprezen worden.

(27) Decimus Brutus, een zeer hoogstaand man en legeraanvoerder, heeft de toegangen tot zijn tempels en herinneringsmonumenten versierd met versregels van zijn grote vriend Accius. En de man die - met Ennius in zijn gevolg - tegen de Aetoliërs heeft oorlog gevoerd, aarzelde niet om de wapenbuit van de wapengod aan de Muzen te wijden. Daarom moeten in een stad waar de bijna nog gewapende legeraanvoerders de naam van dichters en de heiligdommen van de Muzen hebben gerespecteerd, juryleden in toga niet terugschrikken om de Muzen te eren en dichters te beschermen.

(28) En om uw bereidheid daartoe te vergroten, zal ik nu, heren juryleden, mijzelf voor $u$ als voorbeeld nemen en aan $u$ over mijn wellicht al te grote maar toch prijzenswaardige eerzucht een bekentenis doen. Over wat wij tijdens ons consulaat met uw steun voor het welzijn van onze staat, voor het lijfsbehoud van de burgers en voor de gehele gemeenschap hebben kunnen doen, daarover is mijn cliënt een nieuw gedicht begonnen. Toen ik dit had vernomen, heb ik mij met hem in verbinding 
gesteld, omdat dit voornemen mij belangrijk leek en genoegen deed, om de voltooiing ervan te bevorderen. Want verdienste verlangt geen andere beloning voor haar moeiten en gevaren dan eer en roem. Als men die wegneemt, heren juryleden, waarom zouden wij ons dan nog in de korte en geringe tijd van ons leven die moeiten geven?

(29) Als men zich geen voorstelling zou maken van de toekomst en zijn gedachten zou beperken tot de grenzen waarbinnen het tijdperk van ons leven is afgebakend, dan zou men zich toch niet geestelijk afbeulen door zovele inspanningen, zich geestelijk toch niet door zovele zorgen en slapeloosheid laten beklemmen noch zo dikwijls omwille van het leven zelf de strijd aangaan? In werkelijkheid schuilt er juist in de beste mensen een soort dadendrang die dag en nacht ons hart met de prikkel van de roem aandrijft en vermaant dat niet tegelijk met de tijd van leven de nagedachtenis aan onze naam mag worden prijsgegeven maar over de gehele toekomst moet worden uitgestrekt.

(30) Of moeten wij allen zo bekrompen schijnen, wij die ons leven leiden in de maatschappij te midden van moeiten en gevaren, dat wij geloven dat, wanneer wij tot aan het laatste einde zonder rust en ontspanning hebben ademgehaald, alles samen met ons tegelijk vergaat? Hebben vele grote mannen soms ijverig standbeelden en portretten nagelaten als afbeeldingen niet van hun geestkracht maar van hun lichaam? Wij moeten toch veel eerder van onze innerlijke kwaliteiten een beeltenis achterlaten dat door de bekwaamste talenten kunstig is gevormd. Ja, alles wat ik deed, meende ik reeds tijdens het verrichten uit te strooien en uit te zaaien als eeuwig gedenkteken over de hele aarde. Of dit nu na de dood buiten mijn bewustzijn zal geraken of - zoals de meeste wijze filosofen dachten - een deel van mijn bewustzijn zal raken, in elk geval schep ik nu een zeker genoegen in die hoop en gedachte.

(31) Behoudt daarom, heren juryleden, een man wiens rechtschapenheid u gewaarborgd ziet door de waarde van zijn vrienden en door de lange duur van hun vriendschap, een man wiens grote talent - voor zover men het mag beoordelen - gezocht blijkt door de talenten van de meest hoogstaande persoonlijkheden, een man, wiens recht door de tussenkomst van de wet, door het gezag van de stad, het getuigenis van Lucullus en de registers van Metellus wordt bewezen. $\mathrm{Nu}$ dit zo is, vragen wij $\mathrm{u}$, heren juryleden, zo waar deze grote talenten niet alleen een menselijke maar ook een goddelijke aanbeveling verdienen, 
dat mijn cliënt die $\mathrm{u}$, uw veldheren en de successen van het Romeinse volk altijd geëerd heeft, die ook van onze jongste geschiedenis en uw binnenlandse gevaren een eeuwig, roemvol getuigenis belooft af te leggen en tot die mensen behoort die altijd bij allen heilig beschouwd en heilig genoemd zijn, van $\mathrm{u}$ op zulk een wijze bescherming ontvangt dat hij veeleer door uw menselijkheid lijkt te zijn gesteund dan door uw wreedheid onteerd.

(32) Wat ik over de zaak overeenkomstig mijn gewoonte kort en simpel heb uiteengezet, heren juryleden, heeft, naar ik vertrouw, bij allen instemming gevonden. Wat ik in afwijking van de juridische praktijk en gewoonte over het talent van de man en in het algemeen over zijn werkzaamheid heb gezegd, ik hoop, heren juryleden, dat $\mathrm{u}$ dit welwillend hebt willen aanvaarden, zoals de president van de rechtbank ongetwijfeld heeft gedaan.

[Vertaling: Piet Schrijvers]

\section{Toelichting op Livius' Coriolanus-verhaal (Ab Urbe Condita 2.33.3-40.13)}

Gnaeus Marcius Coriolanus (vijfde eeuw voor Chr.) stamde uit een aristocratische familie. Hij maakte zich verdienstelijk voor Rome tijdens de oorlogen tegen de Volscen en de Aequen (volksstammen ten zuiden en oosten van de stad). Zo stond hij aan het hoofd van een kleine groep Romeinen die in het jaar 493 de stad Corioli binnendrong en ten val bracht. Aan deze prestatie dankt hij zijn bijnaam Coriolanus. In de senaat toonde hij zich een arrogante tegenstander van de plebejers, die zich enige tijd hadden teruggetrokken op de Mons Sacer (Heilige Berg) en daarmee hadden bereikt dat er speciale magistraten kwamen om hen te beschermen: de volkstribunen. Toen Rome ten gevolge van verwaarlozing van de landbouw in deze onrustige tijd elders graan duur moest inkopen, verzette Coriolanus zich hevig tegen het verstrekken aan het volk van graan tegen gereduceerde prijzen: de plebejers hadden het graantekort aan zichzelf te wijten en zouden in deze noodsituatie wel inbinden. Zijn betoog wekte zo'n woede dat het volk hem te lijf wilde gaan, maar de tribunen kalmeerden de menigte door Coriolanus een proces aan te zeggen.

Toen het inderdaad tot een proces dreigde te komen en de senaat zich distantieerde van de al te provocerende Coriolanus, liep hij verbitterd over naar de Volscen. In de opnieuw oplaaiende strijd tussen Rome en de Volscen bleek hij wederom een groot aanvoer- 
der: de Romeinen verloren de ene stad na de andere en ten slotte ging hij ertoe over de stad Rome te belegeren. Rome verkeerde toen in groot gevaar, mede omdat de plebejers weinig animo hadden om te vechten tegen de Volscen. Uit wanhoop deden de bange inwoners een beroep op Coriolanus' moeder Veturia en zijn vrouw Volumnia. Beide vrouwen gingen met de zoontjes van Coriolanus naar het Volscische legerkamp en probeerden hem tot inkeer te brengen. De omhelzingen van zijn kinderen, de tranen en smeekbeden van Volumnia, Veturia's felle berispingen en beroep op zijn vaderlandsliefde werden Coriolanus uiteindelijk te machtig: hij trok zijn troepen terug in het Volscische kamp.

Livius laat open hoe het afliep met Coriolanus. Volgens Griekse bronnen, met name de geschiedschrijver Plutarchus, wist hij zich te handhaven in de volksvergadering van de Volscen, maar werd hij later door handlangers van zijn rivalen vermoord. In Cicero's Brutus koos Coriolanus vrijwillig voor de dood en zag ervan af Rome de genadeslag toe te dienen.

Het Coriolanus-verhaal kent een rijke receptiegeschiedenis: auteurs zoals Shakespeare en Brecht hebben de stof verwerkt in een toneelstuk en ook voor diverse componisten, onder wie Beethoven, was het een bron van inspiratie.

\section{Vertaling van Livius' verhaal over Coriolanus}

(33) Tijdens de afscheiding van het plebs aanvaardden Spurius Cassius en Postumus Cominius het consulaat. In dat jaar werd een verdrag met de Latijnse volkeren gesloten. Om dit te sluiten bleef de ene consul in Rome, de ander, naar de Volscische oorlog uitgezonden, versloeg en verjoeg de Volscen wonend in Antium. Tijdens de achtervolging dreef hij hen samen in de stad Longula en nam deze in. Daarna veroverde hij Polusca, ook een Volscische stad, en viel vervolgens met een grote legermacht Corioli aan. In het kamp diende toen Gnaeus Marcius, een lid van de jonge adel, in raad en daad slagvaardig, die later de bijnaam Coriolanus kreeg. Het Romeinse leger was bezig met de belegering van Corioli en concentreerde zich op de stadsbewoners die het ingesloten hield, zonder enige vrees te koesteren voor een van buiten dreigende oorlog, toen het plotseling werd aangevallen door Volscische legioenen die uit Antium waren vertrokken terwijl terzelfder tijd de vijand uit de stad een uitval deed. Op dat moment stond toevallig Marcius op wacht. Met een keurkorps van soldaten heeft hij niet alleen de uitbraak gestuit, maar hij drong dapper door de open 
poort naar binnen en na het aanrichten van een bloedbad in het dichtstbijgelegen stadsdeel greep hij op goed geluk een brandend stuk hout en wierp het op een gebouwencomplex dat boven de stadsmuren uitstak. Het geschreeuw van de stadsbewoners vermengd met het gehuil van vrouwen en kinderen dat, zoals gebruikelijk, bij de eerste schrik opklonk, vergrootte de moed van de Romeinen en bracht verwarring bij de Volscen nu de stad die zij waren komen helpen was ingenomen. De roem van Marcius overschaduwde zozeer de faam van de consul dat als het Latijnse verdrag, dat bij afwezigheid van zijn collega door Spurius Cassius alléén was afgesloten, niet op een bronzen zuil was gememoreerd, de oorlog gevoerd door Postumus Cominius met de Volscen volstrekt vergeten zou zijn.

In hetzelfde jaar stierf Agrippa Menenius, een man die zijn hele leven bij patriciërs en plebejers even geliefd was en bij het plebs nog geliefder was geworden na de afscheiding. Deze middelaar en arbiter van burgerlijke consensus, vertegenwoordiger van de senaat bij het volk dat hij naar de stad had teruggevoerd, bezat geen geld voor zijn eigen begrafenis. Via een hoofdelijke omslag van twee unciae heeft het volk hem begraven.

(34) Tot nieuwe consuls werden gekozen Titus Geganius en Publius Minucius. In hetzelfde jaar, toen buiten de stad de rust door geen oorlog werd verstoord en in Rome de verdeeldheid was verholpen, werd de staat door een veel grotere ramp getroffen. Allereerst was de graanprijs sterk gestegen omdat de akkers door de afscheiding van het plebs onbebouwd waren gebleven, en deze stijging leidde tot hongersnood alsof de stad was ingesloten. De dood van in elk geval de slaven en van het plebs zou gevolgd zijn als de consuls geen voorzorgsmaatregelen hadden genomen door overal graankopers heen te zenden; niet alleen noordwaarts richting Etrurië langs de kust vanaf Ostia en zuidwaarts via de Volscische kust tot aan Cumae, maar tot op Sicilië toe werd er aangekocht. Zozeer dwong de haat van de buren tot een beroep op verre hulp. Toen in Cumae graan was gekocht, werden de schepen door de heerser Aristodemus aan de ketting gelegd als vergoeding voor de bezittingen van de Tarquinii wier erfgenaam hij was. Bij de Volscen en in het Pomptijnse gebied konden zelfs geen aankopen worden gedaan; de handelaren zelf liepen gevaar door de agressiviteit van de bevolking. Van de Etruriërs arriveerde graan via de Tiber; daarmee is het plebs in leven gehouden. Een oorlog, zeer ongelegen bij de zo grote schaarste aan levensmiddelen, zou 
catastrofaal geweest zijn als de Volscen, die al met vijandelijkheden begonnen, niet door een enorme pestepidemie waren getroffen. De vijanden waren door die ramp dermate in paniek geraakt dat ook nog na het minder worden van de epidemie de schrik erin bleef. De Romeinen verhoogden het aantal kolonisten in Velitrae en zonden een nieuwe kolonie naar Norba in de bergen als bolwerk op Pomptijns grondgebied.

Tijdens het consulaat van Marcus Minucius en Aulus Sempronius arriveerde een grote hoeveelheid graan uit Sicilië en in de senaat werd gedebatteerd over de prijs die het plebs ervoor zou moeten betalen. Velen waren van mening dat het moment was aangebroken om het volk weer klein te krijgen en de rechten terug te winnen die door afscheiding en geweld aan de senatoren waren ontfutseld. Het hoogste woord had Marcius Coriolanus, vijand van de tribunische bevoegdheid: 'Als ze de oude graanprijs willen, moeten zij aan de senatoren hun oude rechten teruggeven. Waarom zie ik plebejische magistraten, een machtige Sicinius? Ik voel me onder het juk gezonden en uit rovershanden vrijgekocht. Moet ik deze vernederingen langer verduren dan nodig is? Koning Tarquinius heb ik niet verdragen, moet ik dan Sicinius verdragen? Laat hij zich nu maar afscheiden, het volk wegroepen; de weg naar de Heilige Berg en de rest van de heuvels ligt open. Laten ze het graan maar plunderen van onze akkers zoals ze twee jaar geleden deden; laten ze genieten van een graanprijs die ze door hun eigen waanzin hebben bepaald. Ik durf te zeggen dat zij onder de druk van deze noodtoestand liever zelf landarbeiders zullen worden dan gewapend door een afscheiding de landarbeid verhinderen.' De vraag of de senaat dit had mogen doen is niet zo gemakkelijk te beantwoorden, hij had het naar mijn mening zeker gekund: afschaffing van de tribunische bevoegdheid en van alle rechtsregels die de senaat tegen zijn zin waren opgelegd, als voorwaarden koppelen aan een verlaging van de graanprijs.

(35) Maar dit voorstel leek ook de senaat te hard en deed het woedende plebs bijna naar de wapens grijpen: zij werden nu als vijanden met uithongering bedreigd, van voedsel en levensonderhoud beroofd! Buitenlands graan, dat als enig voedsel onverhoopt door het fortuin was geschonken, werd uit hun mond gegraaid, tenzij de tribunen geboeid werden overgeleverd aan Gnaeus Marcius, tenzij hij tevreden gesteld werd met de huid van het Romeinse volk! Met hem was een nieuwe beul tegen hen opgestaan die hen dwong te kiezen tussen dood en 
slavernij! Toen hij het senaatsgebouw verliet, zou hij gemolesteerd zijn als de tribunen hem niet op dit zeer gelegen moment hadden gedagvaard. Zo werd de woede gesust; iedereen zag dat hij rechter, heer over leven en dood van zijn vijand was geworden. Hooghartig hoorde Marcius aanvankelijk de dreigementen van de tribunen aan: die functie gaf hun het recht om te helpen, niet om te straffen; zij waren volkstribunen, geen senaatstribunen! Maar de vijandigheid van het volk was zo groot geworden dat de senatoren deze moesten sussen met de straf van één man. Toch hebben zij aan de vijandige stemming weerstand geboden en zowel individueel als collectief alles in het werk gesteld. Eerst probeerde men de plannen te verstoren door cliënten her en der te laten posten en burgers individueel van samenkomst en overleg af te schrikken. Vervolgens traden zij tevoorschijn in één stoet - je had kunnen zeggen dat de hele senaat aangeklaagd werd - terwijl zij het volk smeekten om één medeburger, één medesenator, als ze hem niet onschuldig wilden vrijspreken, aan hen ondanks zijn schuld te gunnen. Toen hijzelf op de vastgestelde dag niet verscheen, heeft de vijandige stemming zich doorgezet. Bij verstek veroordeeld ging hij in ballingschap bij de Volscen, bedreigingen uitend tegen zijn vaderland en toen al vervuld van vijandigheid. De Volscen hebben hem bij zijn aankomst vriendelijk ontvangen en werden van dag tot dag vriendelijker naarmate zijn woede tegen zijn landgenoten heftiger tot uitdrukking kwam en vaker zijn klachten of dreigementen werden gehoord. Zijn gastheer was Attius Tullius, toentertijd de meest notabele van de Volscen en een eeuwige vijand van de Romeinen. En zo, terwijl de een door oude haatgevoelens, de ander door recente wrok werd voortgedreven, makkten zij samen plannen voor een oorlog tegen Rome.

(36) Op dat moment werden in Rome voorbereidingen getroffen voor een herhaling van de Grote Spelen en wel om de volgende reden. Op de eerste ochtend van de spelen, toen de opvoering nog niet was begonnen, had het hoofd van een familie een van zijn slaven in het schandblok dwars door de Circus geleid terwijl hij hem geselde. Daarna waren de spelen aangevangen alsof dit voorval geen religieuze gevolgen had. Korte tijd later kreeg Titus Latinius, een man uit het plebs, een droom: hij droomde dat Jupiter zei dat de voordanser hem mishaagd had; als het festival niet op grootse wijze werd herhaald, zou de stad gevaar lopen; die boodschap moest hij aan de consuls gaan overbrengen. Hoewel het hart van de man 
bepaald niet ongodsdienstig was, won toch de eerbied voor de verhevenheid van de magistraten en de vrees dat hij zich voor aller ogen belachelijk zou maken. Die aarzeling kwam hem duur te staan, want binnen enkele dagen verloor hij zijn zoon. Om iedere twijfel over de oorzaak van dit onverwachte verlies weg te nemen verscheen aan de bedroefde man in zijn droom dezelfde gestalte die hem vroeg of de prijs voor zijn verachting van de goden hoog genoeg was; een hogere dreigde als hij niet snel zijn boodschap aan de consuls zou overbrengen. De situatie werd nu urgenter. Toen hij toch bleef aarzelen en uitstellen, werd hij door een hevige ziekte en plotselinge verlamming getroffen. Toen pas nam hij de woede van de goden ter harte. Murw gemaakt door het leed van vroeger en nu riep hij zijn familieleden bijeen en toen hij had verteld wat hij gezien en gehoord had, hoe Jupiter hem meermalen in een droom was verschenen en de goddelijke dreigementen en woede zich in zijn lotgevallen hadden gemanifesteerd, werd hij met duidelijke instemming van alle aanwezigen op een draagbaar naar de consuls op het forum vervoerd. Vandaar is hij op bevel van de consuls het senaatsgebouw binnengedragen en toen hij onder algemene verbazing de senatoren zijn verhaal had gedaan, deed zich een nieuw wonder voor! Het verhaal gaat dat de man die volledig verlamd het senaatsgebouw was binnengedragen, na het vervullen van zijn plicht op eigen benen naar huis is teruggekeerd.

(37) De senaat besloot dat de spelen zo luisterrijk mogelijk moesten worden. Op instigatie van Attius Tullius kwam een grote menigte Volscen op die spelen af. Voordat zij begonnen, ging Tullius (zoals thuis met Marcius was afgesproken) naar de consuls en zei dat er iets was van algemeen belang wat hij vertrouwelijk wilde bespreken. Na verwijdering van de omstanders zei hij: 'Tegen mijn zin moet ik iets zeggen wat voor mijn medeburgers verkeerd kan uitpakken. Ik kom hen niet van een reeds begaan misdrijf beschuldigen, maar ik kom waarschuwen voor wat zij kunnen begaan. De gezindheid van ons volk is veel grilliger dan ik zou willen. Met veel nederlagen hebben wij dit ondervonden; wij zijn immers niet door onze eigen verdienste maar dankzij uw geduld gespaard gebleven. Een grote menigte Volscen is hier nu aanwezig; er zijn spelen; de aandacht van alle burgers is gericht op het festival. Ik herinner mij wat bij een zelfde gelegenheid Sabijnse jongeren in deze stad gedaan hebben. Ik ben bang voor onbezonnen ongeregeldheden. Ik meende, heren consuls, $\mathrm{u}$ dit van tevoren te moeten 
zeggen in uw en ons belang. Wat mijzelf betreft, ik ben van plan meteen naar huis terug te keren, daar ik niet via mijn aanwezigheid door enig woord of daad gecompromitteerd wil raken.' Na deze woorden liep hij weg. Toen de consuls dit vage verhaal van een onbetwiste zegsman aan de senatoren hadden medegedeeld, leidde, zoals zo vaak, de zegsman en niet het verhaal tot voorzorgsmaatregelen, zelfs als deze overbodig zouden zijn. De senaat besloot dat de Volscen de stad moesten verlaten en omroepers werden rondgestuurd met de verordening dat zij allen voor het aanbreken van de nacht moesten vertrekken. Zij werden eerst door een geweldige schrik bevangen en renden naar hun gastverblijven om hun spullen te pakken. Maar bij hun vertrek groeide de verontwaardiging dat zij, als misdadigers en melaatsen, werden weggedreven van de spelen, van de feestdagen, ja in zekere zin van de omgang met goden en mensen.

(38) Toen zij in een bijna gesloten rij hun weg gingen, ontving Tullius, die naar de bron bij Ferentinum vooruit was gereden, de Volscische notabelen één voor één met woorden vol beklag en verontwaardiging, en terwijl zij gretig luisterden naar wat strookte met hun woede, voerde hij hen en via hen de rest van de menigte naar een lager gelegen veld. Daar stak hij, als stond hij voor een volksvergadering, de volgende redevoering af: 'Ook al zouden jullie al het andere vergeten, de vroegere onrechtmatigheden van het Romeinse volk en de nederlagen van onze Volscische gemeenschap, hoe verdragen jullie dan ten slotte deze smaad van vandaag: de spelen zijn begonnen met onze vernedering. Hebben jullie dan niet gemerkt dat zij vandaag over jullie hebben getriomfeerd? Dat jullie vertrek een schouwspel is geweest voor iedereen, voor burgers, vreemdelingen en vele naburige volkeren, dat men voor de ogen van toeschouwers jullie vrouwen en kinderen heeft laten paraderen? Degenen die de stem van de omroeper hebben gehoord, die ons zagen vertrekken, die onze verachtelijke stoet tegenkwamen, wat denken jullie dat ze gedacht hebben, toch zeker dat het ging om een schanddaad, dat wij met onze aanwezigheid bij het festival de spelen zouden schenden en een wandaad zouden begaan, dat wij daarom verdreven werden uit de woonplaats en gemeenschap van godvrezenden? En verder, beseffen jullie niet dat wij leven omdat wij haastig vertrokken zijn? Als dit een vertrek en geen vlucht is. En is deze stad in jullie ogen geen vijandelijke stad? Als jullie er één dag langer waren gebleven, had iedereen daar de dood gevonden. Tegen 
jullie is de oorlog verklaard, tot groot onheil van hen die hem verklaard hebben, als jullie mannen zijn.' En zo van spontane woede vervuld en extra aangevuurd gingen zij naar huis en doordat ieder zijn eigen stamgenoten ophitste, kwam het tot een opstand van alle Volscen.

(39) Tot aanvoerders in deze oorlog verkoos men met instemming van alle volksstammen Attius Tullius en Gnaeus Marcius, de Romeinse balling in wie men ietwat meer vertrouwen had. Dit vertrouwen heeft hij allerminst beschaamd, wat duidelijk maakt dat de Romeinse kracht meer steunde op zijn aanvoerders dan op zijn leger. Hij trok eerst naar Circei, verjoeg er de Romeinse kolonisten en gaf de bevrijde stad in handen van de Volscen. Hij veroverde Satricum, Longula, Polusca en Corioli, steden die recentelijk Romeins waren geworden, daarna Lavinium. Daarvandaan drong hij via zijwegen door naar de Via Latina en bezette vervolgens Corbio, Vetelia, Trebium, Labici en Pedum. Ten slotte marcheerde hij vanuit Pedum op naar Rome, plaatste zijn kamp op vijf mijl afstand van de stad bij de Cluilische afwatering en plunderde van daaruit het Romeinse land. Ofwel uit vijandigheid tegen het plebs ofwel om onenigheid tussen senatoren en plebs te laten ontstaan stuurde hij met de plunderaars bewakers mee die het grondbezit van de patriciërs intact moesten laten. Die onenigheid zou zeker zijn ontstaan - zozeer hitsten de tribunen met hun beschuldigingen het toch al woedende plebs op tegen de notabelen - maar vrees voor de buitenlandse vijand, het machtigste bindmiddel tot consensus, maakte hen eensgezind ondanks hun argwaan en vijandigheid. Er bleef één punt van onenigheid: senaat en consuls stelden alleen vertrouwen in een gewapend optreden, het plebs wilde alles liever dan oorlog. Spurius Nautius en Sextus Furius waren toen consul. Toen zij de legioenen inspecteerden en garnizoenen opstelden langs de muren en waar zij nog verder wachtposten en bewaking wilden, heeft een grote menigte mensen die vrede eisten, hen allereerst met oproerig geschreeuw geïntimideerd en vervolgens gedwongen de senaat bijeen te roepen en voor te stellen om gezanten naar Gnaeus Marcius te sturen. Toen bleek dat het plebs de moed in de schoenen was gezonken, accepteerden de senatoren het voorstel en men zond vredesonderhandelaars naar Marcius. Zij kwamen terug met een bikkelhard antwoord: als de Volscen hun land terugkregen, kon er over vrede worden gepraat; als zij rustigjes van hun oorlogsbuit wilden genieten, dan was hij het onrecht van zijn medeburgers en de vriendelijkheid van 
zijn gastheren niet vergeten en hij zou zijn best doen te laten zien dat ballingschap zijn moed had doen groeien, niet had gebroken. Dezelfde gezanten, nog een keer teruggestuurd, werden niet meer in het kamp ontvangen. Er is overgeleverd dat ook nog priesters in hun officiële gewaden als smekeling naar het vijandige kamp zijn gegaan, die net zo min als de gezanten hem van mening deden veranderen.

(40) Toen kwamen de gehuwde vrouwen in groten getale tezamen bij Veturia, de moeder van Coriolanus, en zijn echtgenote Volumnia. Of hier sprake is geweest van een politiek plan of van angst van vrouwen, kan ik niet precies nagaan; in elk geval hebben zij weten te bereiken dat Veturia, een oude vrouw, en Volumnia met haar twee kinderen van Marcius naar het vijandelijke kamp gingen en omdat de mannen de stad niet met de wapens konden verdedigen, de vrouwen dit met smeekbeden en tranen zouden proberen. Toen men bij het kamp was gearriveerd, werd de komst van een grote stoet vrouwen aan Coriolanus gemeld. Hij die toch al niet onder de indruk was geweest van de officiële waardigheid van gezanten en de oog en hart beroerende heiligheid van priesters, was nog veel stijfkoppiger tegenover vrouwentranen. Een van zijn vrienden, die door het opmerkelijk vertoon van droefheid te midden van de overige vrouwen Veturia had ontdekt, staande tussen haar schoondochter en kleinkinderen, zei: 'Als mijn ogen mij niet bedriegen, staan daar je moeder en je vrouw en kinderen.' Ontsteld sprong Coriolanus op uit zijn zetel en wilde zijn moeder omhelzen, maar haar smeekbede sloeg om in woede en zij zei: 'Laat me eerst weten, voor ik jouw omhelzing accepteer, of ik bij een vijand of bij mijn zoon ben gekomen, of ik in jouw kamp een krijgsgevangene of je moeder ben. Hebben mijn lange leven en ongelukkige ouderdom mij hiertoe gesleept dat ik jou in ballingschap moest zien en vervolgens als vijand? Heb jij het bestaan om het land te verwoesten, waar jij werd geboren en gevoed? Hoe vijandig en dreigend je zijn gebied ook binnenkwam, is je woede toen niet van je afgevallen? Toen Rome in zicht was, dacht je toen niet: "Binnen die muren bevinden zich mijn huis, mijn huisgoden, mijn moeder, mijn vrouw en kinderen." Als ik geen moeder was geweest, zou Rome niet worden bedreigd; als ik geen zoon zou hebben, zou ik vrij in een vrij land gestorven zijn. Maar mij kan niets meer overkomen wat schandelijker is voor jou en ellendiger voor mij. Mijn ellende, hoe groot ook, zal niet lang duren: denk aan hen die, als je doorgaat, een vroegtijdige dood of lange slavernij moeten ver- 
wachten.' De daaropvolgende omhelzingen van zijn vrouw en kinderen, het gehuil van de hele groep vrouwen en hun gejammer om hun eigen lot en dat van het vaderland hebben de man ten slotte murw gemaakt. Toen hij zijn familieleden omhelsd had, stuurde hij hen weg en trok zijn troepen terug van de stad. Na de terugtocht van zijn leger uit het Romeinse land zou hij door de wrok die dit opriep gewelddadig aan zijn eind zijn gekomen, maar over de manier waarop zijn de lezingen verschillend. Bij Fabius, verreweg de oudste zegsbron, vind ik dat Coriolanus een hoge leeftijd heeft bereikt; hij vertelt tenminste dat deze aan het eind van zijn leven voortdurend zei dat ballingschap voor een oud man veel ellendiger is. De Romeinse mannen hebben de vrouwen hun roem niet misgund - zozeer leefde men toen nog zonder andermans roem te kleineren - en als herinnering hieraan heeft men een tempel gebouwd en gewijd aan Fortuna Muliebris ('Het Vrouwelijk Fortuin').

[Vertaling: Piet Schrijvers] 


\section{Grammaticale analyse}

\subsection{Analyse van zinnen}

Geef een grammaticale analyse van de volgende zinnen, de ingebedde predicaties incluis. Begin met het predicaat van de hoofdzin. Soms is het lastig uit te maken of er sprake is van een verplicht of optioneel zinsdeel (argument of satelliet).

voorbeeld: heri piratae praedam magnam diviserunt

diviserunt

piratae

praedam magnam

predicaat

argument, subject

argument, object

NOMINALE GROEP

praedam

hoofd

magnam

attribuut

heri

satelliet, adjunct

1. favent pietati dei. (Liv. 44.1.11)

2. $\quad$ accipe quid contra haec iuvenis responderit. (Hor. S. 2.3.233)

3. ortu solis videmus partem quandam caeli rubere. (Sen. Nat. 1.5.8)

4. accipite hanc animam meque his exsolvite curis. (Verg. A. 4.652)

5. mortem servituti antepono. (Cic. Fam. 10.27.2)

6. ille volat nullos strepitus facientibus alis / per tenebras. (Ov. Met. 11.650)

7. dum haec in Venetis geruntur, Q. Titurius Sabinus cum iis copiis, quas a Caesare acceperat, in fines Unellorum pervenit. (Caes. Gal. 3.16.4)

8. ${ }^{*}$ legatos ad Dumnorigem Aeduum mittunt, ut eo deprecatore a Sequanis impetrarent. (Caes. Gal. 1.9.2)

9.* nemo laborat, ut obscura sua cupiditas esse videatur. (Cic. Ver. 2.126-127)

10.* hic, ne deficeret, metuens avidusque videndi / flexit amans oculos. (Ov. Met. 10.56-57) 


\section{WOORDEN EN TOELICHTINGEN}

1. favere, faveo

gunstig gezind zijn

2. accipere, accipio

vernemen

3. ortus, ortus opkomst rubere, rubeo rood zijn

4. Dido spreekt haar laatste woorden op de brandstapel. accipere aanvaarden exsolvere, exsolvo verlossen, bevrijden van

5. servitus, servitutis slavernij

6. / ille volare, volo markeert het einde van de versregel strepitus, strepitus te weten Somnus, de Slaap

ala vliegen lawaai tenebrae vleugel

7. Veneti fines (plur.) Unelli duisternis kustvolk in het zuiden van Bretagne gebied

Keltisch volk in het noorden van Normandie

8. De Helvetiërs zijn het subject van deze zin

Aeduus

deprecator

Sequani impetrare, impetro

9. laborare, laboro cupiditas
Haeduer. De Haeduers zijn een Keltische volksstam tussen de Loire en Saône.

verdediger

Keltische volksstam in de Franche-Comté en westelijke Jura

bereiken, gedaan krijgen

zich inspannen

hebzucht

10. Deze versregels gaan over Orpheus die op weg naar de bovenwereld omkijkt naar Eurydice.

deficere, deficio

achterblijven

avidus + gen. begerig, verlangend

flectere, flecto

draaien, wenden

\subsection{Analyse van een tekst}

Lees de onderstaande passage uit Cicero's Pro Archia en de vertaling ervan. Beantwoord de vragen.

Cicero Pro Archia 4: Cicero heeft de opening van zijn verdedigingsrede voor de dichter Archias afgerond en begint met een beschrijving van het leven van de dichter. 
1. nam ut primum ex pueris excessit Archias atque ab eis artibus, quibus aetas puerilis ad humanitatem informari solet, se ad scribendi studium contulit, primum Antiochiae - nam ibi natus est loco nobili - celebri quondam urbe et copiosa atque eruditissi-

5. mis hominibus liberalissimisque studiis adfluenti, celeriter antecellere omnibus ingeni gloria coepit. post in ceteris Asiae partibus cunctaque Graecia sic eius adventus celebrabatur ut famam ingeni exspectatio hominis, exspectationem ipsius adventus admiratioque superaret.

Want zodra Archias de kinderschoenen was ontgroeid en na het onderwijs waardoor het kind tot algemene beschaving pleegt te worden gevormd, een loopbaan als schrijver nastreefde, begon hij allereerst in Antiochië - daar is hij namelijk geboren uit voorname familie -, ooit een drukbevolkte en welvarende stad met een hoogontwikkelde bevolking en een zeer rijk cultuurleven, snel door zijn roemvol talent boven allen uit te blinken.

Later werd in de rest van Klein-Azië en in heel Griekenland zijn optreden dermate bejubeld dat de reputatie van zijn talent door de verwachting en de verwachting door zijn persoonlijk optreden en de bewondering werden overtroffen.

\section{Opdrachten}

1. Noteer de connectoren die in deze passage voorkomen.

2. Noteer de coördinatoren die worden gebruikt in deze passage.

3. Noteer de subordinatoren die in deze passage voorkomen

4. Geef een zo compleet mogelijke grammaticale analyse van de eerste, als volgt ingekorte volzin:

ut primum ex pueris excessit Archias atque ab eis artibus, quibus aetas puerilis ad humanitatem informari solet, se ad scribendi studium contulit, primum Antiochiae celeriter antecellere omnibus ingeni gloria coepit. 



\section{Naamvallen}

\subsection{Naamvalsgebruik in zinnen}

Omschrijf het gebruik van de naamvallen van de gecursiveerde constituenten. Vertaal de zinnen. voorbeeld: doceo te linguam Latinam te accusativus, object (tweede argument) bij het drieplaatsige doceo linguam Latinam accusativus, complement (derde argument) NB linguam Latinam blijft bij passivering in de accusativus staan; het gaat hier om een dubbele accusativusconstructie

1. sol cuncta sua luce complet. (Cic. Rep. 6.17)

2. homo mundum et elegans animal est. (Sen. Ep. 92.12)

3. nobili genere nati sunt. (Cic. Ver. 5.180)

4. cur ego id curem? (Pl. Poen. 354)

5. ei legioni castrisque Q. Tullium Ciceronem praefecit ducentosque equites ei attribuit. (Caes. Gal. 6.32.6)

6. tecum sunt quae fugis. (Sen. Ep. 104.20)

7. post paulum concidit ac suis saluti fuit. (Caes. Gal. 7.50.6)

8. nec latuere doli fratrem Iunonis. (Verg. A. 1.130)

9. egressi optata potiuntur Troes harena. (Verg. A. 1.172)

10. Agesilaus statura fuit humili et corpore exiguo. (Nep. Ag. 8.1)

11. rex dat munus ituris. (Ov. Met. 13.679)

12. o genitor, nec te miseret nataeque tuique? (Verg. A. 7.360)

13. leto gaudete duorum. (Ov. Met. 10.39)

14.* non mediocris ingeni est moderari orationi. (cf. Cic. Q.Fr. 1.1.38)

15.* quam metui ne quid Libyae tibi regna nocerent! (Verg. A. 6.694)

WOORDEN EN TOELICHTINGEN

1. complere, compleo vullen met

2. mundus (adiectivum) verfijnd animal (levend) wezen

5. Caesar is het subject van de zin.

ducenti

tweehonderd

attribuere, attribuo

ter beschikking stellen 
$\begin{array}{ll}\text { 7. post paulum } & \text { kort daarna } \\ \text { concidere, concido } & \text { sneuvelen }\end{array}$

8. latuere =latuerunt

frater te weten Neptunus

dolus list

Iunonis verbinden met doli

9. egredi, egressus van boord gaan

optare wensen, verlangen

Troes de Trojanen

harena strand

10. Agesilaus koning van Sparta

statura gestalte

exiguus klein, kort

11. munus, muneris (neutrum) geschenk

12. Koningin Amata spreekt tot haar man Latinus; zij wil dat hun dochter Lavinia niet met de Trojaan Aeneas zal trouwen, maar met Turnus, de koning van de Rutuliërs.
genitor
vader
nata
dochter

13. Orpheus spreekt tot de goden van de Onderwereld; met duorum bedoelt hij zijn geliefde Eurydice en zichzelf.

14. mediocris moderari + dat.

middelmatig, gering matigen

15. Een uitroep van vader Anchises, gericht tot zijn zoon Aeneas.
quam
hoe, wat
quid
= aliquid (bijwoordelijk gebruikt)
Libyae regna
het Libische rijk (van koningin Dido)

\subsection{Naamvallen invullen in zinnen}

Zet het woord/de woorden tussen vierkante haakjes in de juiste naamval, licht het antwoord toe en vertaal de zinnen.

1. [quis?] faveam potius? (Catul. 100.5)

2. rogat illa [Iuppiter] munus. (cf. Ov. Met. 3.288)

3. [nemo] paenitebit ad hunc te sermonem impulisse. (Cic. de Orat. 1.209)

4. Orgetorix et Dumnorix se [tota Gallia] potiri posse sperant. (Caes. Gal. 1.3.8)

5. [Marcellinus noster] ego nondum despero; etiamnunc servari potest. (Sen. Ep. 29.4) 
6. Graecia capta ferum victorem cepit et artes / intulit [agrestis Latium]. (Hor. Ep. 2.1.156-7)

7. amemus patriam, pareamus [senatus], consulamus [boni]. (Cic. Sest. 142)

8. placet [Stoici] suo quamque rem nomine appellare. (Cic. Fam. 9.22.1)

9. et [clades veteres vestrae] et [beneficia nostra] erga vos obliti estis? (Liv. 8.6.5)

10.* siste gradum [tu]que [aspectus] ne subtrahe [noster]. (Verg. $A$. 6.465)

WOORDEN EN TOELICHTINGEN

1. potius liever

3. impellere ad aanzetten tot

5. etiamnunc ook nu nog, nog steeds

6. Graecia (Griekenland) is subject. capere, cepi, captus overwinnen ferus woest

victorem bedoeld zijn de Romeinen

artes kunsten en wetenschappen, beschaving

agrestis boers

Latium landstreek waarin Rome ligt

7. boni loyale mannen

consulere zorgen voor

8. appellare noemen

9. clades, cladis (femininum) nederlaag

erga + acc. tegenover, jegens

10. Aeneas spreekt tot Dido in de Onderwereld.

sistere gradum staan blijven

aspectus, aspectus blik

se subtrahere zich onttrekken

noster hoort bij aspectus

\subsection{Naamvallen invullen in zinnen}

Kruis de juiste naamval aan van het woord/de woorden tussen vierkante haakjes, of (zie vraag 6) benoem de naamval van de gevraagde vormen. In sommige gevallen zijn meerdere goede antwoorden mogelijk. 
1. [ceteri] pudeat, si qui ita se litteris abdiderunt ut nihil possint ex eis ad communem adferre fructum. (Cic. Arch. 12; qui=aliqui) Anderen moeten zich maar schamen, als zij zich zo in de boeken hebben begraven dat ze daaruit niets kunnen bijdragen aan het nut van het algemeen.

$\bigcirc$ ceterorum

ceteris (dativus)

$\bigcirc$ ceteros

ceteris (ablativus)

2. [ille] corpus erat durum patiensque laborum. (Ov. Tr. 1.5.63) Hij had een lichaam dat gehard was en bestand tegen inspanningen.

illius

$\bigcirc$ illi

illum

illo

3. ea [fatalis lex] geruntur. (Ov. Met. 3.316)

Die dingen voltrekken zich door een noodlottige wet.

fatalis legis

fatali legi

fatalem legem

$\bigcirc$ fatali lege

4. sunt bestiae quaedam, in quibus inest aliquid simile [virtus]. (Cic. Fin. 5.38)

Er zijn bepaalde dieren, waarin iets aanwezig is dat lijkt op moed.

virtutis

$\bigcirc$ virtuti

virtutem

$\bigcirc$ virtute

5. onus animi deponendum est: non ante [tu] ullus placebit locus. (Sen. Ep. 28.2)

Je moet je zwaarmoedigheid afleggen: eerder zal geen enkele plaats jou bevallen.

$\bigcirc$ tui

tibi

te (accusativus)

$\bigcirc$ te (ablativus) 
6. me illis quidem haec verberat verbis. (Pl. Truc. 112; quidem is adverbium)

Mij foltert zij met die woorden.

Wat is achtereenvolgens de naamval van me en van illis?

accusativus \& dativus

accusativus \& ablativus

ablativus \& dativus

ablativus \& ablativus

7. utinam [ego] hoc idem vere dicere liceret. (Cic. Off. 3.1)

Och mocht ik ditzelfde naar waarheid zeggen.

mei

mihi

me (accusativus)

me (ablativus)

8. ego me etsi [peccatum] absolvo, [supplicium] non libero. (Liv. 1.58.10; uitspraak van Lucretia nadat zij is verkracht door de koningszoon Tarquinius)

Al spreek ik mij vrij van misdaad, van straf bevrijd ik mij niet.

peccati \& supplicii

peccato \& supplicio (dativi)

peccatum \& supplicium

$\bigcirc$ peccato \& supplicio (ablativi)

9. nullum est enim fundamentum [haec crimina]. (Cic. Cael. 30) Er is immers geen grond voor deze beschuldigingen.

$\bigcirc$ horum criminum

$\bigcirc$ his criminibus (dativus)

$\bigcirc$ haec crimina (accusativus)

$\bigcirc$ his criminibus (ablativus)

10. dea [carmen] digna est. (Ov. Met. 5.345)

De godin is een lied waardig.

carminis

carmini

carmen

carmine 
11. [tertius dies] ad flumen Elaver pontes refecit. (Caes. Gal. 7.53.4) De derde dag herstelde hij bij de rivier de Elaver de bruggen. (Elaver: zijrivier van de Loire)

$\bigcirc$ tertii diei

tertio diei

tertium diem

$\bigcirc$ tertio die

12. aequora [ego] terrent et ponti tristis imago. (Ov. Met. 11.427) De watervlakten en het grimmige beeld van de zee maken mij bang.

mei

$\bigcirc$ mihi

me (accusativus)

$\bigcirc$ me (ablativus)

13. ea pars animi, quae [mens] et [ratio] sit particeps. (Cic. Div. 1.60) Dat deel van de geest dat deel heeft aan verstand en rede.

mentis et rationis

$\bigcirc$ menti et rationi

mentem et rationem

$\bigcirc$ mente et ratione

14. O crudelis Alexi, nihil [mea carmina] curas? (Verg. Ecl. 2.6; nihil: bijwoordelijk gebruikt)

O wrede Alexis, bekommer jij je helemaal niet om mijn liederen?

meorum carminum

meis carminibus (dativus)

mea carmina (accusativus)

meis carminibus (ablativus)

15. Sic ait et [dictum] citius tumida aequora placat. (Verg. A. 1.142; over Neptunus)

Zo spreekt hij en sneller dan een woord/vliegensvlug kalmeert hij het gezwollen zeevlak.

$\bigcirc$ dicti

$\bigcirc$ dicto (dativus)

$\bigcirc$ dictum

$\bigcirc$ dicto (ablativus) 
16. [tres] ferme [horae] pugnatum est et ubique atrociter. (Liv. 22.6.1) Gedurende bijna drie uur is er gevochten en overal op gruwelijke wijze.

$\bigcirc$ trium horarum

$\bigcirc$ tribus horis

tres horas

$\bigcirc$ tribus horis

17. una erat [magnus usus] res praeparata ab nostris. (Caes. Gal. 3.14.5)

Eén zaak was door onze mannen voorbereid om tot groot nut te zijn.

$\bigcirc$ magni usus

$\bigcirc$ magno usui

$\bigcirc$ magnum usum

$\bigcirc$ magno usu

18. aliae nationes servitutem pati possunt; [populus Romanus] est propria libertas. (Cic. Phil. 6.18)

Andere volken kunnen slavernij verdragen; vrijheid is het Romeinse volk eigen.

$\bigcirc$ populi Romani

$\bigcirc$ populo Romano (dativus)

$\bigcirc$ populum Romanum

$\bigcirc$ populo Romano (ablativus)

19. parvi sunt foris arma, nisi consilium est [domus]. (Cic. Off. 1.76) Buiten de stad zijn wapens van weinig waarde, als er thuis/in de stad geen sprake is van overleg/beleid.

$\bigcirc$ domui

$\bigcirc$ domum

$\bigcirc$ domo

$\bigcirc$ domi

20.id esse [optimus] puteamus quod erit [rectissimus]. (Cic. Sest. 142)

Laten wij menen dat dit het allerbeste is wat allerjuist zal zijn.

$\bigcirc$ optimum, rectissimum (beide nominativus)

$\bigcirc$ optimum, rectissimum (nominativus en accusativus)

$\bigcirc$ optimum, rectissimum (beide accusativus)

$\bigcirc$ optimum, rectissimum (accusativus en nominativus) 


\section{4* Alle naamvallen van zinnen analyseren}

Benoem in onderstaande zinnen alle naamvallen (met uitzondering van de voorzetselverbindingen) en vermeld hun syntactische functie. Vertaal de zinnen.

1. omne hoc tempus iucundissima quiete transmisi. (Plin. Ep. 7.27.9)

2. duritia silicis nullis magis quam ferientibus nota est. (Sen. Vita beata 27.3)

3. mens immota manet, lacrimae volvuntur inanes. (Verg. A. 4.449)

4. 'metus hostium' recte dicitur, et cum timent hostes et cum timentur. (Gel. 9.2.13)

5. sunt homines quos libidinis infamiaeque suae neque pudeat neque taedeat. (Cic. Verr. 1.1.35)

6. neque domi neque in urbe invenio quemquam qui illum viderit. (Pl. Am. 1010)

7. senatui nimis atrox visa sententia est. (Liv. 2.35.1)

8. magna fiducia ad nostras naves procedunt, quibus praeerat D. Brutus. (Caes. Civ. 1.56.4)

9. est proprium stultitiae aliorum vitia cernere, oblivisci suorum. (Cic. Tusc. 3.73)

10. castra a cohortibus, quae praesidio erant relictae, industrie defendebantur, multo etiam acrius a Thracibus barbarisque auxiliis. (Caes. Civ. 3.95.3)

11. Quintia formosa est multis; mihi candida, longa, / recta est. (Catul. 86.1-2)

12. nuntiant decemviris ut omni ope ab seditione milites contineant. (Liv. 3.50.1)

13. vivamus, mea Lesbia, atque amemus, / rumoresque senum severiorum / omnes unius aestimemus assis! (Catul. 5.1-3)

14. nemo asperitate ea est et immanitate naturae, congressus ut hominum fugiat atque oderit. (cf. Cic. Amic. 87)

15. amicis utilitati et rei publicae emolumento esse viri boni est. (Cic. de Orat. 1.34)

WOORDEN EN TOELICHTINGEN

1. iucundus aangenaam

transmittere, transmitto doorbrengen

2. duritia hardheid

silex, silicis steen

ferire stoten 
3. Aeneas is subject; hij is ongevoelig voor de verwijten van Dido. inanis

4. recte (adverbium) vergeefs

5. libido, libidinis terecht infamia

lust

7. nimis slechte naam atrox, atrocis al te sententia

8. fiducia gruwelijk

9. vitium

10. cohors, cohortis beslissing, uitspraak zelfvertrouwen fout cohort (het tiende deel van een Romeins legioen) industrie (adverbium) ijverig auxilia (plur.) hulptroepen

11. formosus mooi, knap candidus verblindend

12. decemviri

ops, opis seditio, seditionis tienmannen (college bestaande uit tien mannen)

middel

continere aliquem $a b$

opstand

iemand afhouden van

13. rumor, rumoris

roddel

senex, senis

oude man

as, assis

munteenheid, van weinig waarde

14. immanitas, immanitatis onmenselijkheid

15. utilitas, utilitatis nut emolumentum voordeel

\subsection{Naamvallen invullen in een tekst}

Lees de onderstaande passage uit Cicero's Pro Archia en de bijbehorende vertaling. Vul de ontbrekende naamvallen in en licht de keuze toe.

Cicero Pro Archia 5: Cicero geeft een schets van het literaire klimaat dat in Italië heerste toen Archias hierheen kwam op zeventienjarige leeftijd (102 voor Chr.). Hij vertelt ook hoe de dichter werd ontvangen in Zuid-Italië en Rome.

(1) erat Italia tum plena [Graecae artes ac disciplinae], studiaque haec et in Latio vehementius tum colebantur quam nunc in [idem; oppida], et hic [Roma] propter tranquillitatem [res publica] non 
neglegebantur. (2) itaque hunc et Tarentini et Locrenses et Regini et Neapolitani [civitas ceteraque praemia] donarunt, et omnes qui aliquid de ingeniis poterant iudicare, [cognitio] atque [hospitium] dignum existimarunt. (3) hac tanta [celebritas] famae cum esset iam [absentes] notus, [Roma] venit [Marius consul et Catulus]. (4) nactus est primum [consules ei], quorum alter res ad scribendum maximas, alter cum [res gestae] tum etiam studium atque auris adhibere posset. (5) statim Luculli, cum praetextatus etiam tum Archias esset, [is] domum suam receperunt.

(1) Italië was toen vervuld van Griekse kunsten en wetenschappen en deze geestelijke bezigheden werden toen ook in Latium met grotere ijver beoefend dan nu in dezelfde steden, en hier in Rome werden zij dankzij de rustige politieke toestand niet verwaarloosd. (2) De inwoners van Tarentum, Locri, Regium en Napels hebben hem het burgerschap en andere onderscheidingen verleend, en allen die tot enig oordeel over getalenteerdheid in staat waren, achtten hem hun kennismaking en gastvrijheid waardig. (3) Toen hij door zo'n roemvolle reputatie ook al bekend was bij wie hem niet hadden gezien, arriveerde hij in Rome tijdens het consulaat van Marius en Catulus. (4) Hij trof er allereerst consuls aan van wie de een zeer grote daden als stof tot schrijven kon bieden, de ander niet alleen zeer grote daden maar ook belangstelling en een luisterend oor. (5) De Luculli hebben Archias terstond in hun huis opgenomen, ook al droeg hij toen nog de kindertoga.

\section{TOELICHTINGEN}

2. hunc te weten: Archias

Tarentini etc. inwoners van steden in Zuid-Italie existimarunt = existimaverunt

4. auris accusatious pluralis domum suam accusativus van richting (adjunct)

5. Luculli de invloedrijke familie van Lucius Licinius Lucullus

\subsection{Naamvallen invullen in een tekst}

Lees het onderstaande fragment uit Cicero's Pro Archia en de vertaling ervan. Vul de ontbrekende naamval in en vermeld de syntactische functie. 
Pro Archia 18-19: Cicero gaat uitgebreid in op de waarde en het belang van literaire vorming en begaafdheid. Hij steekt de loftrompet over het dichterschap.

(1) qua re suo iure noster ille Ennius [sanctus] appellat poetas, quod quasi deorum aliquo dono atque munere commendati [nos] esse videantur. (2) sit igitur, iudices, [sanctus] apud vos, humanissimos homines, hoc poetae nomen quod nulla umquam barbaria violavit. (3) saxa atque solitudines [vox] respondent, bestiae saepe immanes [cantus] ${ }^{*}$ flectuntur atque consistunt; nos instituti [res optimae] non poetarum voce moveamur? (4) [Homerus] Colophonii civem esse dicunt suum, Chii suum vindicant, Salaminii repetunt, Smyrnaei vero [suus] esse confirmant itaque etiam delubrum eius in oppido dedicaverunt, permulti alii praeterea pugnant inter se atque contendunt. (5) ergo illi [alienus], quia poeta fuit, post mortem etiam expetunt; nos hunc [vivus], qui et voluntate et legibus [noster] est, repudiamus, praesertim cum omne olim studium atque omne ingenium contulerit Archias ad populi Romani gloriam laudemque celebrandam? (6) nam et Cimbricas res adulescens attigit et [ipse ille C. Marius], qui durior ad haec studia videbatur, iucundus fuit.

* cantus: singularis

(1) Hierom noemt onze beroemde Ennius dichters terecht 'heilig', omdat zij ons geschonken schijnen te zijn als een dierbare gave en gift der goden. (2) Laat daarom, heren juryleden, bij $\mathrm{u}$ - zeer beschaafde mensen - deze naam van dichter heilig zijn, een naam die geen enkel barbarenland ooit heeft geschonden. (3) Rotsen en eenzame streken antwoorden op hun stem, wilde dieren worden vaak door hun gezang getemd en tot staan gebracht; moeten wij, die door de hoogste beschaving zijn gevormd, dan niet worden ontroerd door het dichterwoord? (4) Bewoners van Colophon beweren dat Homerus hun burger is, Chioten eisen hem op als hun Chioot, Salaminiërs claimen hem, inwoners van Smyrna verzekeren dat hij echt van hen is en hebben daarom ook een heiligdom ter zijner ere in hun stad opgericht, en nog vele anderen betwisten en vechten om hem. (5) Anderen claimen dus een vreemdeling, zelfs nog na zijn dood, omdat hij een dichter was; wij wijzen hem hier af, bij zijn leven, iemand die en naar eigen verlangen en op grond van de wetten de onze is, terwijl Archias, let wel, sinds lange tijd al zijn werkkracht en al zijn talent in dienst heeft gesteld van de verheerlijking van de roem en de glorie van het Romeinse volk? (6) Want de Cimbrische oorlogen, daar is hij in zijn jeugd aan begonnen en hij was 
geliefd zelfs bij Gaius Marius, die voor dergelijke literaire activiteiten geen al te grote sympathie leek te bezitten.

\section{TOELICHTINGEN}

1. Ennius

4. Colophon en Smyrna

Chios

Salamis
Romeins dichter (239-169)

steden in Klein-Azië

eiland in de Egeïsche Zee

eiland voor de kust van Zuid-west Attica 


\section{Infinitivus}

\subsection{Analyse van zinnen}

Vermeld met welke gebruikswijze van de infinitivus we te maken hebben in de onderstaande zinnen. Kies uit:

subject

complement bij tweeplaatsig werkwoord

complement bij drieplaatsig werkwoord

a.c.i. als subject

a.c.i. als object

n.c.i.

infinitivus historicus.

Vertaal de zinnen vervolgens.

1. sollemnia ludorum intermitti nefas est. (Liv. 5.1.4)

2. dominari illi volunt, vos liberi esse. (Sal. Jug. 31.23)

3. turpe est adulescenti vinci a sene. (Sen. Con. 10.2.6)

4. interim cotidie Caesar Haeduos frumentum flagitare. (Caes. Gal.1.16.1)

5. iungere equos Titan velocibus imperat Horis. (Ov. Met. 2.118)

6. is, quem nos dictatorem nominari legimus, apud antiquos 'magister populi' vocatus est. (Sen. Ep. 108.31)

7. posse pati volui nec me temptasse negabo. (Ov. Met. 10.25)

8.* consul arma extemplo capere milites iussit. (Liv. 34.46.8)

9.* vetiti sunt propius accedere. (V.Max. 1.7.4)

10.* prudentissima civitas Atheniensium fuisse traditur. (Cic. S. Rosc. 70)

WOORDEN EN TOELICHTINGEN
1. sollemnia (plur.)
plechtigheden
ludi (plur.)
spelen
intermittere
onderbreken
2. dominari
heersen, gebieden
3. senex, senis
oude man, grijsaard
4. cotidie
dagelijks 
Haedui

Haeduers, volksstam tussen de Loire en Saône

flagitare

eisen

5. Titan is de zon en Horae (Horen) zijn de godinnen van de groei en de wisseling van de seizoenen.

$\begin{array}{ll}\text { iungere } & \text { inspannen } \\ \text { velox } & \text { snel }\end{array}$

6. legere

lezen

magister populi oude benaming voor dictator

vocare noemen

7. Orpheus spreekt tot de goden van de Onderwereld over het verlies van zijn geliefde Eurydice.

$\begin{array}{ll}\text { temptasse } & =\text { temptavisse } \\ \text { temptare } & \text { proberen }\end{array}$

8. extemplo meteen

9. propius (adverbium) naderbij

10. prudens verstandig

civitas stad, stadstaat

\subsection{Analyse van zinnen}

Vermeld met welke gebruikswijze van de infinitivus we te maken hebben in de onderstaande zinnen. Kies uit:

subject

complement bij tweeplaatsig werkwoord

complement bij drieplaatsig werkwoord

a.c.i. als subject

a.c.i. als object

n.c.i.

infinitivus historicus.

Vertaal de zinnen vervolgens.

1. suos quisque debet tueri. (Cic. Att.16.16c.1)

2. tibicines prohibiti erant in aede Iovis vesci. (cf. Liv. 9.30)

3. Pompeium nobis amicissimum constat esse. (Cic. Att. 1.12.3)

4. Saguntini parentes suos liberos emori quam servos vivere maluerunt. (Cic. Parad. 24)

5. sperabat propediem magnas copias sese habiturum. (Sal. Cat. 56)

6. non licet fratrem necare. (Sen. Con. 7.1.16)

7. ibi partem suarum copiarum traducere conati sunt. (Caes. Gal. 2.9.4) 
8. Orpheum poetam docet Aristoteles numquam fuisse. (Cic. N.D. 1.107)

9. illi homines parum putantur cauti fuisse. (Cic. S. Rosc. 117)

10. me hoc nihil agere delectat. (Cic. de Orat. 2.113)

\section{WOORDEN EN TOELICHTINGEN}

1. tueri

beschermen

2. tibicen, tibicinis

fluitspeler

vesci

eten

3. amicus (adiectivum)

vriendschappelijk gezind

4. Saguntinus

Saguntijns (Saguntum is een stad in Spanje, ten noorden van het huidige Valencia)

emori sterven

5. propediem (adverbium) heel spoedig habiturum = habiturum esse sese $=$ se

8. Aristoteles Griekse filosoof en universeel geleerde (384-322), leerling van Plato

fuisse bestaan hebben

9. parum (adverbium) cautus te weinig, niet genoeg voorzichtig

10. agere doen

\section{3* Analyse van zinnen}

Vermeld met welke gebruikswijze van de infinitivus we te maken hebben in de onderstaande zinnen. Kies uit:

subject

complement bij tweeplaatsig werkwoord

complement bij drieplaatsig werkwoord

a.c.i. als subject

a.c.i. als object

n.c.i.

infinitivus historicus.

Vertaal de zinnen vervolgens.

1. centuriones occidi iussit. (Tac. Hist. 1.59.1)

2. quem defendis sperat se absolutum iri. (Cic. Sull. 21)

3. repente omnes tristitia invasit: festinare, trepidare neque loco neque homini cuiquam satis credere. (Sal. Cat. 31.1)

4. domus illa, quae temptata esse scelere isto nefario dicitur, plena est integritatis. (Cic. Cael. 55) 
5. Agesilaus Lacedaemonius dixit responso deum se ex collibus pugnare iussum esse. (Front. Str. 1.10.3)

\section{WOORDEN EN TOELICHTINGEN}

$\begin{array}{ll}\text { 2. absolvere } & \text { vrijspreken } \\ \text { 3. repente } & \text { plotseling } \\ \text { invadere } & \text { zich meester maken van } \\ \text { festinare } & \text { zich haasten } \\ \text { trepidare } & \text { sidderen } \\ \text { 4. temptare } & \text { beproeven, op de proef stellen } \\ \text { nefarius } & \text { gruwelijk } \\ \text { integritas, integritatis } & \text { rechtschapenheid } \\ \text { 5. Agesilaus } & \text { zie oefening 2.1, zin } 10 \\ \text { responsum } & \text { orakel(uitspraak) } \\ \text { deum } & =\text { deorum } \\ \text { collis, collis } & \text { heuvel }\end{array}$

\subsection{Analyse van een tekst}

Lees de onderstaande passage uit Cicero's Pro Archia en de vertaling. Vermeld de gebruikswijze van de tien gecursiveerde infinitivi. Kies uit:

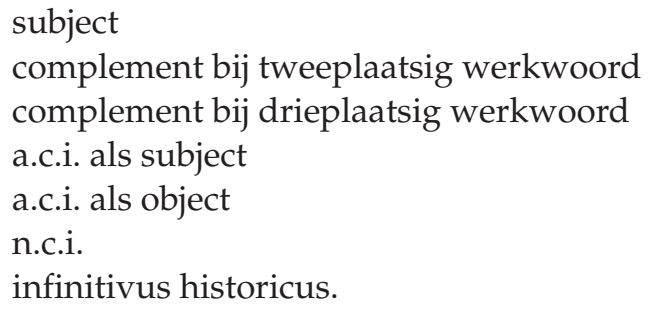

Cicero Pro Archia 8: Cicero stelt de vraag aan de orde of Archias daadwerkelijk het burgerrecht van de Zuid-Italische stad Heraclea bezit.

(1) si nihil aliud nisi de civitate ac lege dicimus, nihil dico amplius; causa dicta est. (2) quid enim horum infirmari, Gratti, potest? (3) Heracleaene tum hunc esse ascriptum negabis? (4) adest vir summa auctoritate et religione et fide, M. Lucullus, qui se non opinari sed scire, non audisse sed vidisse, non interfuisse sed egisse dicit. (5) adsunt Heraclienses legati; nobilissimi homines, huius iudicii causa cum mandatis et cum publico testimonio venerunt; qui hunc ascriptum Heracliensem esse dicunt. (6) hic tu tabulas desideras Heracliensium publicas, quas Italico bello incenso tabulario interisse 
scimus omnes? (7) est ridiculum ad ea quae habemus nihil dicere, quaerere quae habere non possumus, et de hominum memoria tacere, litterarum memoriam flagitare et, cum habeas amplissimi viri religionem, integerrimi municipi ius iurandum fidemque, ea quae depravari nullo modo possunt repudiare, tabulas quas idem dicis solere corrumpi desiderare.

(1) Als wij alleen over wettig burgerrecht spreken, hoef ik verder niets meer te zeggen: mijn verdedigingsrede is dan afgelopen. (2) Welk onderdeel van de inhoud kan ontkracht worden, Grattius? (3) Zult $\mathrm{u}$ ontkennen dat hij toen in Heraclea is ingeschreven? (4) Als getuige is aanwezig een man met zeer groot gezag, oprecht en betrouwbaar, Marcus Lucullus, die zegt dat hij dit niet meent maar weet, niet gehoord maar gezien heeft, niet erbij geweest is maar het heeft doorgevoerd. (5) Als getuigen zijn aanwezig vertegenwoordigers uit Heraclea, mensen van zeer hoge komaf, omwille van dit proces met volmachten en met een officieel getuigenis gekomen, die verklaren dat hij als burger van Heraclea staat ingeschreven. (6) U mist nu de officiële bevolkingsregisters van Heraclea, die - zoals wij allen weten - tijdens de Italische oorlog bij een brand in het archief verloren zijn gegaan? (7) Het is lachwekkend om op wat wij voor ons hebben niets terug te zeggen, maar te vragen om wat wij niet kunnen hebben, over de menselijke herinnering te zwijgen, maar een geschreven herinnering te vorderen en terwijl $u$ het gewetensvol getuigenis van een zeer hooggeacht man en de beëdigde verklaring van een integere gemeenschap bezit, datgene wat op geen enkele manier vervalst kan worden, af te wijzen en te vragen om registers die naar uw eigen zeggen vervalst plegen te worden.

\section{TOELICHTINGEN}

2. Grattius is de aanklager.

4. Marcus Licinius Lucullus is de broer van Lucius Licinius Lucullus, Archias' patronus.

6. Met Italico Bello is de Bondgenotenoorlog bedoeld (91-89).

\section{5* Analyse van een tekst}

Lees de onderstaande passage en de bijbehorende vertaling. In de Latijnse tekst komt een aantal a.c.i.-constructies voor. Noteer de participia die zelfstandig (dus zonder esse of fuisse) het predicaat van een a.c.i. vormen. 
Livius 2.35: Coriolanus stelt in een senaatsvergadering voor om het volk een deel van de rechten te ontnemen (o.a. de tribunicia potestas) die het had verworven na de terugtrekking op de Heilige Berg.

(1) et senatui nimis atrox visa sententia est et plebem ira prope armavit: fame se iam sicut hostes peti, cibo victuque fraudari; peregrinum frumentum, quae sola alimenta ex insperato fortuna dederit, ab ore rapi, nisi $\mathrm{Cn}$. Marcio vincti dedantur tribuni, nisi de tergo plebis Romanae satisfiat; eum sibi carnificem novum exortum, qui aut mori aut servire iubeat. (2) in exeuntem e curia impetus factus esset, ni peropportune tribuni diem dixissent. (3) ibi ira est suppressa; se iudicem quisque, se dominum vitae necisque inimici factum videbat. (4) contemptim primo Marcius audiebat minas tribunicias: auxilii, non poenae ius datum illi potestati, plebisque, non patrum tribunos esse. (5) sed adeo infensa erat coorta plebs ut unius poena defungendum esset patribus.

(1) Maar dit voorstel leek ook de senaat te hard en deed het woedende plebs bijna naar de wapens grijpen: zij werden nu als vijanden met uithongering bedreigd, van voedsel en levensonderhoud beroofd! Buitenlands graan, dat als enig voedsel onverhoopt door het fortuin was geschonken, werd uit hun mond gegraaid, tenzij de tribunen geboeid werden overgeleverd aan Gnaeus Marcius, tenzij hij tevredengesteld werd met de huid van het Romeinse volk! Met hem was een nieuwe beul tegen hen opgestaan die hen dwong te kiezen tussen dood en slavernij! (2) Toen hij het senaatsgebouw verliet, zou hij gemolesteerd zijn als de tribunen hem niet op dit zeer gelegen moment hadden gedagvaard. (3) Zo werd de woede gesust; iedereen zag dat hij rechter, heer over leven en dood van zijn vijand was geworden. (4) Hooghartig aanhoorde Marcius aanvankelijk de dreigementen van de tribunen: die functie gaf hun het recht om te helpen, niet om te straffen; zij waren volkstribunen, geen senaatstribunen! (5) Maar de vijandigheid van het volk was zo groot geworden dat de senatoren deze moesten sussen met de straf van één man.

\section{6* Analyse van een tekst}

Lees de onderstaande passage en de bijbehorende vertaling. Geef van de gecursiveerde infinitivi aan op welke manier ze gebruikt zijn. Kies uit: 
subject

complement bij tweeplaatsig werkwoord

complement bij drieplaatsig werkwoord

a.c.i. als subject

a.c.i. als object,

n.c.i.

infinitivus historicus.

Livius 2.39.9-12: Er heerst hongersnood in Rome. Coriolanus stelt voor het volk een deel van zijn rechten te ontnemen. Hij wordt door de senaat, die bang is voor de woede van het volk, verbannen naar het gebied van de Volscen. Daar begint hij samen met zijn gastheer Attius Tullius een oorlog tegen Rome. Door deze bedreiging verdwijnen de geschillen tussen patriciërs en plebejers in Rome naar de achtergrond. Alleen op één punt bestaat er een grondig verschil van mening: de senatoren en consuls willen een gewapend treffen aangaan, de plebejers niet.

(1) Sp. Nautius iam et Sex. Furius consules erant. (2) eos recensentes legiones, praesidia per muros aliaque, in quibus stationes vigiliasque esse placuerat, loca distribuentes, multitudo ingens pacem poscentium primum seditioso clamore conterruit, deinde vocare senatum, referre de legatis ad $\mathrm{Cn}$. Marcium mittendis coegit. (3) acceperunt relationem patres, postquam apparuit labare plebis animos; missique de pace ad Marcium oratores atrox responsum rettulerunt: si Volscis ager redderetur, posse agi de pace: si praeda belli per otium frui velint, memorem se et civium iniuriae et hospitum beneficii adnisurum, ut appareat exsilio sibi inritatos, non fractos esse animos. (4) iterum deinde iidem missi non recipiuntur in castra. (5) sacerdotes quoque suis insignibus velatos isse supplices ad castra hostium traditum est; nihilo magis quam legatos flexisse animum.

(1) Spurius Nautius en Sextus Furius waren toen consul. (2) Toen zij de legioenen inspecteerden en garnizoenen opstelden langs de muren en waar zij nog verder wachtposten en bewaking wilden, heeft een grote menigte mensen die vrede eisten, hen allereerst met oproerig geschreeuw geïntimideerd en vervolgens gedwongen de senaat bijeen te roepen en voor te stellen om gezanten naar Gnaeus Marcius te sturen. (3) Toen bleek dat het plebs de moed in de schoenen was gezonken, accepteerden de senatoren het voorstel en men zond vredesonderhandelaars naar Marcius. Zij kwamen terug met een bikkelhard antwoord: als de Volscen hun land terugkregen, kon er over vrede worden gepraat; als zij rustigjes van hun oorlogsbuit 
wilden genieten, dan was hij het onrecht van zijn medeburgers en de vriendelijkheid van zijn gastheren niet vergeten en hij zou zijn best doen te laten zien dat ballingschap zijn moed had doen groeien, niet had gebroken. (4) Dezelfde gezanten, nog een keer teruggestuurd, werden niet meer in het kamp ontvangen. (5) Er is overgeleverd dat ook nog priesters in hun officiële gewaden als smekeling naar het vijandige kamp zijn gegaan, die net zo min als de gezanten hem van mening deden veranderen. 


\section{Participium}

\subsection{Analyse van zinnen}

Bespreek het gebruik van de participia in de onderstaande zinnen: vermeld hun naamval en syntactische gebruikswijze en kies daarbij uit:

attributief

substantivisch

predicativum

dominant (o.a. ablativus absolutus)

a.c.p.

Vertaal de zinnen vervolgens.

1. haec in contione questus ex provincia fugit. (Caes. Civ. 1.30.5)

2. verba refers aures non pervenientia nostras. (Ov. Met. 3.462)

3. audi moriens quid dicat Epicurus. (Cic. Fin. 2.96)

4. vidi ego pro nivea pugnantes coniuge tauros. (Ov. Am. 2.12)

5. at Venus interea Neptunum exercita curis / adloquitur. (Verg. A. 5.779-780)

6. nos patria amissa dominis parere superbis / cogemur. (Verg. A. 12.236-237)

7. ducunt volentem fata, nolentem trahunt. (Sen. Ep. 107.11)

8. rex Ephesum omisso quod incohaverat bello redit. (Liv. 35.15.7)

9. multas per gentes et multa per aequora vectus / advenio has miseras, frater, ad inferias. (Catul. 101.1-2)

10.* fama dediti benigneque excepti Segestis vulgata est. (cf. Tac. Ann. 1.59.1)

\section{WOORDEN EN TOELICHTINGEN}

1. contio, contionis vergadering queri, questus + accusativus klagen over

2. Narcissus spreekt tegen zijn spiegelbeeld in het water waarop hij verliefd is. auris, auris oor pervenire bereiken 
3. Epicurus moriens

4. niveus coniunx, coniugis

5. exercitus (p.p.p.)

6. amittere superbus

7. fata (plur.)

8. Ephesus omittere, omitto incohare
Griekse wijsgeer (c. 340-260)

te verbinden met Epicurus

sneeuwwit

wijfje

verontrust

verliezen

trots

lot(sbeschikkingen)

Ephese (stad in Klein-Azië)

verliezen

beginnen

9. De ik-figuur staat bij het graf van zijn broer en spreekt de overledene toe. aequor, aequoris zee inferiae (plur.) dodenoffers, rituelen

10. dedi (pass. van dedere, dedo) zich overgeven Segestes, gen. Segestis. Segestes is de tegenspeler en schoonvader van Arminius. (Arminius was een Germaanse vrijheidsheld, overwinnaar van de slag in het Teutoburgerwoud.) $\begin{array}{ll}\text { benigne (adverbium) } & \text { welwillend } \\ \text { excipere } & \text { ontvangen, begroeten }\end{array}$

\subsection{Analyse van zinnen}

Bespreek het gebruik van de participia in de onderstaande zinnen: vermeld hun naamval en syntactische gebruikswijze en kies daarbij uit:

attributief

substantivisch

predicativum

dominant (o.a. ablativus absolutus)

a.c.p.

Vertaal de zinnen vervolgens.

1. arbitratus id bellum celeriter confici posse eo exercitum adduxit. (Caes. Gal. 3.28.1)

2. audentes forsque deusque iuvat. (Ov. Fast. 2.782)

3. ter Pater exstructos disiecit fulmine montes. (Verg. G. 1.283)

4. abdito intra vestem ferro profiscitur. (Liv. 1.12.5)

5. Laelium potius audiam dicentem. (cf. Cic. N.D. 3.5.15)

6. ${ }^{*}$ solus hic inflexit sensus animumque labentem / impulit. (Verg. A. 4.22-23) 
7. metu subactus Remus rem aperit. (Liv. 1.5.5)

8. saepe fugam Danai Troia cupiere relicta / moliri. (Verg. A. 2.108-109)

9. hic mutat merces surgente a sole. (Hor. S. 1.4.29)

10.* quantae copiae transgresso in Italiam Hannibali fuerint, nequaquam inter auctores constat. (Liv. 21.38.2)

WOORDEN EN TOELICHTINGEN

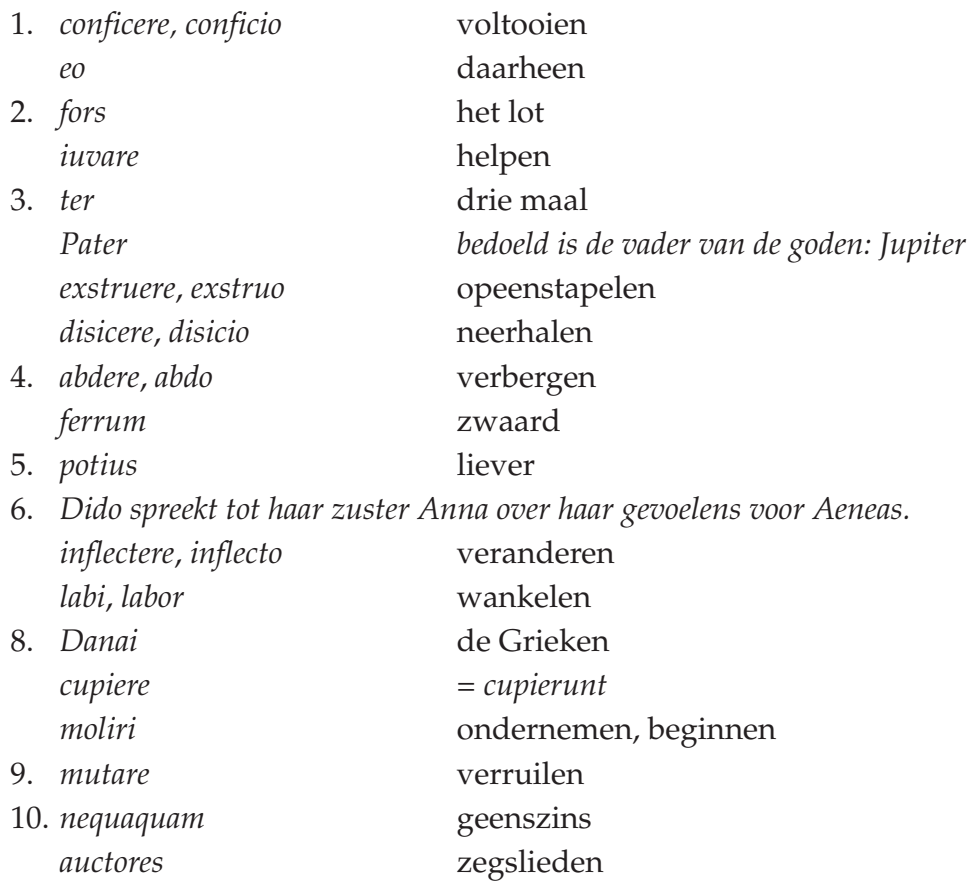

\section{3* Analyse van een tekst}

1. Bespreek het gebruik van de gecursiveerde participia in de volgende passage uit Livius' verslag van de Tweede Punische Oorlog. Kies uit: attributief, substantivisch, predicativum, dominant (o.a. ablativus absolutus), a.c.p.

2. Noteer kort voor welke constructie de vertaler gekozen heeft bij het vertalen van de participia (deelwoord, zelfstandig naamwoord, bijwoordelijke bijzin, relatieve bijzin, nieuwe hoofdzin, nog anders?). 
Livius 23.1: Na de beroemde overwinning bij Cannae (216 voor Chr.) probeert Hannibal zijn greep op Zuid-Italië te versterken door de belegering van een aantal andere steden, waaronder Napels.

(1) Hannibal post Cannensem pugnam castraque capta ac direpta confestim ex Apulia in Samnium moverat, accitus in Hirpinos a Statio Trebio, pollicente se Compsam traditurum esse. (2) Compsanus erat Trebius nobilis inter suos; sed premebat eum Mopsiorum factio, familiae per gratiam Romanorum potentis. (3) post famam Cannensis pugnae volgatumque Trebi sermonibus adventum Hannibalis cum Mopsiani urbem excessissent, sine certamine tradita urbs Poeno praesidiumque acceptum est. (4) ibi praeda omni atque impedimentis relictis, exercitu partito Magonem regionis eius urbes aut deficientes ab Romanis accipere aut detractantis cogere ad defectionem iubet. (5) ipse per agrum Campanum mare inferum petit, oppugnaturus Neapolim, ut urbem maritimam haberet. (6) ubi fines Neapolitanorum intravit, Numidas partim in insidiis - et pleraeque cavae sunt viae sinusque occulti -, quacumque apte poterat, disposuit, alios prae se actam praedam ex agris ostentantes obequitare portis iussit. (7) in quos, quia nec multi et incompositi videbantur, cum turma equitum erupisset, ab cedentibus consulto tracta in insidias circumventa est; (8) nec evasisset quisquam, ni mare propinquum et haud procul litore naves, piscatoriae pleraeque, conspectae peritis nandi dedissent effugium. (9) aliquot tamen eo proelio nobiles iuvenes capti caesique sunt, inter quos et Hegeas, praefectus equitum, intemperantius cedentes secutus cecidit. (10) ab urbe oppugnanda Poenum absterruere conspecta moenia haudquaquam prompta oppugnanti.

(1) Na de veldslag bij Cannae en na de inname en verwoesting van het vijandelijke kamp was Hannibal snel uit Apulië naar Samnië getrokken; hij was tegen de Hirpini in het geweer geroepen door Statius Trebius die hem beloofde Compsa in handen te zullen spelen. (2) Trebius was een inwoner van Compsa, hij stond in hoog aanzien bij zijn medeburgers maar werd bedreigd door de partij van de Mopsii, een familie die haar macht dankte aan de invloed van de Romeinen. (3) Toen na het gerucht over de slag bij Cannae en - via uitlatingen van Trebius - het bekend worden van de nadering van Hannibal de aanhangers van de Mopsii de stad verlaten hadden, is deze zonder slag of stoot overgedragen aan Hannibal en men accepteerde een Punisch bezettingsgarnizoen. (4) Daar liet hij de totale buit en de legertros achter, splitste het leger en gaf Mago opdracht de steden uit die streek die van de Romeinen afvielen in overgave 
aan te nemen en de steden die dit weigerden tot afvallen te dwingen. (5) Zelf trok hij via Campanië naar de Tyrrheense zee om Napels te bestormen en daarmee een havenstad in bezit te krijgen. (6) Toen hij het Napolitaanse grondgebied was binnengedrongen, legde hij een deel van de Numidiërs op geschikte punten in hinderlaag - er zijn daar talrijke holle wegen en verborgen bochten - anderen gaf hij bevel de buit van de landerijen goed zichtbaar voor zich uit te drijven en naar de poorten te rijden. (7) Toen een eskadron ruiters tegen hen een uitval had gewaagd - ze leken weinig in aantal en ongeordend -, werd het eskadron door de opzettelijk terugwijkende tegenstanders in de hinderlaag getrokken en omsingeld. (8) Niemand zou zijn ontkomen als niet de naburige zee en de aanblik van schepen niet ver van de kust - vooral vissersschepen - een ontsnapping hadden geboden aan degenen die konden zwemmen. (9) Toch zijn enige notabelen in dit gevecht gegrepen en gedood, onder wie ook Hegeas, commandant van de ruiterij, die sneuvelde toen hij de wijkende vijanden al te onbeheerst achtervolgde. (10) De aanblik van de muren (niet direct gemakkelijk om te bestormen) deed de Puniër terugdeinzen voor een bestorming van de stad.

\section{TOELICHTINGEN}

1. Apulië en Samnië zijn landstreken in Zuid-Italië.

4. Mago (gen. Magonis) is de jongste broer van Hannibal. detractantis: accusatious pluralis

10. absterruere $=$ absterruerunt

\section{4* Analyse van een tekst}

Lees de onderstaande inleiding, Latijnse tekst en vertaling. Bespreek het gebruik van de gecursiveerde participia. Kies uit: attributief substantivisch predicativum dominant (o.a. in ablativus absolutus) a.c.p.

Livius 2.33.3-7: Hier wordt het allereerste militaire optreden van Gnaeus Marcius Coriolanus geschilderd en zijn succes in de oorlog tegen de stad Corioli in 493 voor Chr. 
(1) per secessionem plebis Sp. Cassius et Postumius Cominius consulatum inierunt. (2) iis consulibus cum Latinis populis ictum est foedus. (3) ad id feriendum consul alter Romae mansit; alter ad Volscum bellum missus Antiates Volscos fundit fugatque; compulsos in oppidum Longulam persecutus moenibus potitur. (4) inde protinus Poluscam, item Volscorum, cepit; tum magna vi adortus est Coriolos. (5) erat tum in castris inter primores iuvenum Cn. Marcius, adulescens et consilio et manu promptus, cui cognomen postea Coriolano fuit. (6) cum subito exercitum Romanum Coriolos obsidentem atque in oppidanos quos intus clausos habebat intentum, sine ullo metu extrinsecus belli, Volscae legiones profectae ab Antio invasissent, eodemque tempore ex oppido erupissent hostes, forte in statione Marcius fuit. (7) is cum delecta militum manu non modo impetum erumpentium rettudit, sed per patentem portam ferox inrupit; caede in proxima parte urbis facta ignem temere arreptum imminentibus muro aedificiis iniecit.

(1) Tijdens de afscheiding van het plebs aanvaardden Spurius Cassius en Postumus Cominius het consulaat. (2) In dat jaar werd een verdrag met de Latijnse volkeren gesloten. (3) Om dit te sluiten bleef de ene consul in Rome, de ander, naar de Volscische oorlog uitgezonden, versloeg en verjoeg de Volscen wonend in Antium. Tijdens de achtervolging dreef hij hen samen in de stad Longula en nam deze in. (4) Daarna veroverde hij Polusca, ook een Volscische stad en viel toen met een grote legermacht Corioli aan. (5) In het kamp diende toen Gnaeus Marcius, een lid van de jonge adel, in raad en daad slagvaardig, die later de bijnaam Coriolanus kreeg. (6) Het Romeinse leger was bezig met de belegering van Corioli en concentreerde zich op de stadsbewoners die het ingesloten hield, zonder enige vrees te koesteren voor een van buiten dreigende oor$\log$, toen het plotseling werd aangevallen door Volscische legioenen die uit Antium waren vertrokken, terwijl terzelfder tijd de vijand uit de stad een uitval deed. Op dat moment stond toevallig Marcius op wacht. (7) Met een keurkorps van soldaten heeft hij niet alleen de uitbraak gestuit, maar hij drong dapper door de open poort naar binnen en na het aanrichten van een bloedbad in het dichtstbij gelegen stadsdeel greep hij op goed geluk een brandend stuk hout en wierp het op een gebouwencomplex dat boven de stadsmuren uitstak. 


\section{5* Analyse van een tekst}

Lees de onderstaande inleiding, Latijnse tekst en vertaling. Bespreek het gebruik van de gecursiveerde participia. Kies uit:

attributief

substantivisch

predicativum

dominant (o.a. in ablativus absolutus)

a.c.p.

deel van het predicaat in een a.c.i.

Livius 2.36.1-8: Livius beschrijft hoe men in Rome voorbereidingen treft voor een herhaling van de opening van de Grote Spelen. Op de dag van de openingsceremonie was er namelijk iets misgegaan.

(1) Ludi forte ex instauratione Magni Romae parabantur. instaurandi haec causa fuerat. (2) Ludis mane servum quidam pater familiae, nondum commisso spectaculo, sub furca caesum medio egerat circo; coepti inde Ludi, velut ea res nihil ad religionem pertinuisset. (3) haud ita multo post Tito Latinio, de plebe homini, somnium fuit; visus Iuppiter dicere sibi Ludis praesultatorem displicuisse; nisi magnifice instaurarentur ii Ludi, periculum urbi fore; iret, ea consulibus nuntiaret. (4) quamquam haud sane liber erat religione animus, verecundia tamen maiestatis magistratuum timorque vicit, ne in ora hominum pro ludibrio abiret. (5) magno illi ea cunctatio stetit; filium namque intra paucos dies amisit. (6) cuius repentinae cladis ne causa ei dubia esset, aegro animi eadem illa in somnis obversata species visa est rogitare, satin magnam spreti numinis haberet mercedem; maiorem instare ni eat propere ac nuntiet consulibus. (7) iam praesentior res erat. (8) cunctantem tamen ac prolatantem ingens vis morbi adorta est debilitate subita. (9) tunc enimvero deorum ira admonuit. (10) fessus igitur malis praeteritis instantibusque, consilio propinquorum adhibito, cum visa atque audita et obversatum totiens somno Iovem, minas irasque caelestes repraesentatas casibus suis exposuisset, consensu inde haud dubio omnium qui aderant in forum ad consules lectica defertur. (11) inde in Curiam iussu consulum delatus, eadem illa cum patribus ingenti omnium admiratione enarrasset, ecce aliud miraculum: qui captus omnibus membris delatus in Curiam esset, eum functum officio pedibus suis domum redisse traditum memoriae est. 
(1) Op dat moment werden in Rome voorbereidingen getroffen voor een herhaling van de Grote Spelen en wel om de volgende reden. (2) Op de eerste ochtend van de Spelen, toen de opvoering nog niet was begonnen, had het hoofd van een familie een van zijn slaven in het schandblok dwars door de Circus geleid terwijl hij hem geselde. Daarna waren de Spelen aangevangen alsof dit voorval geen religieuze gevolgen had. (3) Korte tijd later kreeg Titus Latinius, een man uit het plebs, een droom: hij droomde dat Jupiter zei dat de voordanser hem mishaagd had; als het Festival niet op grootse wijze werd herhaald, zou de stad gevaar lopen; die boodschap moest hij aan de consuls gaan overbrengen. (4) Hoewel het hart van de man bepaald niet ongodsdienstig was, won toch de eerbied voor de verhevenheid van de magistraten en de vrees dat hij zich voor aller ogen belachelijk zou maken. (5) Die aarzeling kwam hem duur te staan, want binnen enkele dagen verloor hij zijn zoon. (6) Om iedere twijfel over de oorzaak van dit onverwachte verlies weg te nemen verscheen aan de bedroefde man in zijn droom dezelfde gestalte die hem vroeg of de prijs voor zijn verachting van de goden hoog genoeg was; een hogere dreigde als hij niet snel zijn boodschap aan de consuls zou overbrengen. (7) De situatie werd nu urgenter. (8) Toen hij toch bleef aarzelen en uitstellen, werd hij door een hevige ziekte en plotselinge verlamming getroffen. (9) Toen pas nam hij de woede van de goden ter harte. (10) Murw gemaakt door het leed van vroeger en nu riep hij zijn familieleden bijeen en toen hij had verteld wat hij gezien en gehoord had, hoe Jupiter hem meermalen in een droom was verschenen en de goddelijke dreigementen en woede zich in zijn lotgevallen hadden gemanifesteerd, werd hij met duidelijke instemming van alle aanwezigen op een draagbaar naar de consuls op het forum vervoerd. (11) Vandaar is hij op bevel van de consuls het senaatsgebouw binnengedragen en toen hij onder algemene verbazing de senatoren zijn verhaal had gedaan, deed zich een nieuw wonder voor! Het verhaal gaat dat de man die volledig verlamd het senaatsgebouw was binnengedragen, na het vervullen van zijn plicht op eigen benen naar huis is teruggekeerd. 


\section{Gerundi(v)um}

\subsection{Analyse van zinnen}

Geef de naamval en syntactische functie van de gerundiumvormen die in onderstaande zinnen voorkomen. Vertaal de zinnen.

1. agebat infelicem Alexandrum furor aliena vastandi. (Sen. Ep. 94.62)

2. quid est ineptius quam de dicendo dicere? (Cic. de Orat. 1.112)

3. Dumnorix Aeduus insuetus navigandi mare timebat. (Caes. Gal. 5.6.3)

4. nox ruit, Aenea, nos flendo ducimus horas. (Verg. A. 6.539)

5. ille verbis ad audiendum iucundis uti potuit. (cf. Cic. de Orat. 1.213)

6. quae sit veniendi causa, requirit. (Ov. Met. 7.479)

7. id temporis omne consumebatur in legendo, scribendi otium non erat. (cf. Cic. Off. 2.4.8)

\section{WOORDEN EN TOELICHTINGEN}

1. Alexander

furor

aliena

2. ineptus

3. Aeduus

Alexander de Grote (356 - 323), koning van Macedonië

razernij

acc. plur. neutr.

dwaas

Haeduer. De Haeduers zijn een Keltische volksstam tussen de Loire en Saône.

4. De Sibylle spreekt tot Aeneas.

Aenea

ducere

5. iucundus

6. requirere, requiro

7. consumere, consumo id temporis vocativus

doorbrengen, verdoen

aangenaam

vragen

besteden

deze tijd 


\subsection{Analyse van zinnen}

Geef de naamval en syntactische functie van de gerundivumvormen die in onderstaande zinnen voorkomen en vermeld ook waarmee ze congrueren. Vertaal de zinnen.

1. nunc mihi dicenda est regis fuga. (Ov. Fast. 2.685)

2. quis enim ignorat eos usque ad hanc diem retinere illam immanem ac barbaram consuetudinem hominum immolandorum? (Cic. Font. 30)

3. certa praecepta in emendis iuvencis arator sequi debet. (Col. 6.1)

4. Menapii legatos ad eum pacis petendae causa mittunt. (Caes. Gal. 6.6.2)

5. superstitione tollenda religio non tollitur. (cf. Cic. Div. 2.148)

6. si vis me flere, dolendum est primum ipsi tibi. (Hor. A.P. 102103)

7.* bello gerendo M. Catonem praefecisti. (Cic. Dom. 20)

WOORDEN EN TOELICHTINGEN

1. fuga vlucht

2. usque ad + accusativus tot aan immanis gruwelijk immolare offeren

3. praecepta (plur.) voorschriften iuvencus jonge stier arator ploeger, boer

4. Menapii Menapiërs, volk in België

5. superstitio, superstitionis bijgeloof

\subsection{Analyse van zinnen}

Vermeld of in onderstaande zinnen een gerundium en/of gerundivum voorkomt. Bespreek de gebruikswijze van deze gerundi(v)umvormen en vertaal de zinnen.

1. nostra oratio multitudinis est auribus accommodanda. (Cic. de Orat. 2.159)

2. multi patrimonium effuderunt inconsulte largiendo. (Cic. Off. 2.54)

3. quidquid erit, superanda omnis fortuna ferendo est. (Verg. $A$. 5.710) 
4. nactus idoneam ad navigandum tempestatem tertia fere vigilia naves solvit. (Caes. Gal. 4.23.1)

5. multi venisse tempus premendae plebis putabant. (Liv. 2.34.8)

6. maxime est utendum consilio amicorum. (Cic. Off. 1.91)

7. tu coniunx, tibi fas animum temptare precando. (Verg. A. 4.113)

8. novandi res occasio data est. (Liv. 24.29.3)

9. navium magnam copiam ad transportandum exercitum pollicebantur. (Caes. Gal. 4.17.8)

10. tibi fama petatur / inter mortales faciendae maxima lanae. (Ov. Met. 6.30-31)

11. ${ }^{*}$ populus Romanus consuli potius Crasso quam privato Africano bellum gerundum dedit. (Cic. Phil. 2.118)

12. ${ }^{*}$ perfugam Fabricius reducendum curavit ad Pyrrhum. (cf. Cic. Off. 3.86)

\section{WOORDEN EN TOELICHTINGEN}

1. oratio

redevoering

accommodare

aanpassen

2. patrimonium

erfdeel

effundere, effundo

verkwisten

inconsulte (adverbium)

ondoordacht

3. superare

overwinnen

4. tempestas, tempestatis weer(sgesteldheid)

vigilia

wacht, de nacht was van zonsondergang tot zonsopgang verdeeld in vier nachtwakes

6. consilium raad

7. Venus spreekt tot Juno.

coniunx

Juno is de echtgenote van Jupiter

temptare

vermurwen

10. De godin Athena spreekt tot Arachne.

tibi datious auctoris bij petatur

petatur coniunctious adhortatious

lanam facere weven

maxima te verbinden met fama

11. Africanus bedoeld is P. Scipio Africanus

12. perfuga overloper

\subsection{Analyse van een tekst}

Lees de onderstaande Latijnse tekst met de bijbehorende vertaling. Vermeld van de zes gecursiveerde vormen of er sprake is van een 
gerundium of gerundivum en licht kort toe hoe het betreffende gerundi(v)um is gebruikt.

Cicero Pro Archia 14: Cicero betoogt dat het verlangen om in geschriften te worden verheerlijkt, hemzelf ertoe gebracht heeft zich als advocaat en politicus in te zetten voor het algemeen belang.

(1) nam nisi multorum praeceptis multisque litteris mihi ab adulescentia suasissem nihil esse in vita magno opere expetendum nisi laudem atque honestatem, in ea autem persequenda omnis cruciatus corporis, omnia pericula mortis atque exsili parvi esse ducenda, numquam me pro salute vestra in tot ac tantas dimicationes atque in hos profligatorum hominum cotidianos impetus obiecissem. (2) sed pleni omnes sunt libri, plenae sapientium voces, plena exemplorum vetustas; quae iacerent in tenebris omnia, nisi litterarum lumen accederet. (3) quam multas nobis imagines non solum ad intuendum verum etiam ad imitandum fortissimorum virorum expressas scriptores et Graeci et Latini reliquerunt! (4) quas ego mihi semper in administranda re publica proponens animum et mentem meam ipsa cogitatione hominum excellentium conformabam.

(1) Want als ik niet van jongs af aan dankzij de voorschriften van velen en veel geschriften mij de overtuiging had eigengemaakt dat er geen hoger levensdoel bestaat dan eer en roem, maar dat bij het nastreven ervan alle lichamelijke kwellingen, alle gevaren van dood en verbanning moeten worden geminacht, dan zou ik mij nooit voor uw welzijn in zovele en zo grote conflicten hebben gestort en deze dagelijkse aanvallen van verdorven figuren hebben getrotseerd. (2) Maar alle boeken staan er vol van, alle uitspraken van filosofen staan er vol van, de historische voorbeelden zijn er vol van, die alle in duisternis verwaarloosd zouden liggen als het schijnsel van de literatuur hen niet zou verlichten. (3) Talrijk zijn de beeltenissen van de dapperste mannen die de Griekse en Latijnse schrijvers ons hebben nagelaten niet alleen ter aanschouwing maar ook ter navolging! (4) Hen hield ik altijd voor ogen tijdens mijn maatschappelijke loopbaan en ik vormde aldus mijn hart en verstand juist door het denken aan deze voortreffelijke mensen. 


\section{Tempus}

\subsection{Analyse van een tekst}

Bespreek het gebruik van de narratieve tijden in deze fabel van Phaedrus (1.1).

lupus et agnus

ad rivum eundem lupus et agnus venerant,

siti compulsi. superior stabat lupus,

longeque inferior agnus. tunc fauce improba

latro incitatus iurgii causam intulit:

'cur,' inquit, 'turbulentam fecisti mihi

aquam bibenti?' laniger contra timens:

'qui possum, quaeso, facere quod quereris, lupe?

a te decurrit ad meos haustus liquor.'

repulsus ille veritatis viribus

'ante hos sex menses male,' ait, 'dixisti mihi.'

respondit agnus: 'equidem natus non eram.'

'pater, hercle, tuus,' ille inquit, 'male dixit mihi;'

atque ita correptum lacerat iniusta nece.

haec propter illos scripta est homines fabula

qui fictis causis innocentes opprimunt.

Wolf en Lam

Eens waren Wolf en Lam bij dezelfde beek beland,

door dorst gedreven. Wolf stond meer stroomopwaarts en veel verder neerwaarts Lam. Toen zocht de schurk ruzie, geprikkeld als hij was door vraatzucht in zijn keel: 'Waarom heb jij terwijl ik aan het drinken was,

het water vies gemaakt?' Woldrager sprak bedeesd:

'Hoe kan ik, Wolf, de oorzaak zijn van jouw verwijt?

Het water stroomt van jou naar mijn drinkplaatsje toe.'

Wolf zei, verslagen door de kracht van deze waarheid:

'Een half jaar geleden heb jij mij nog belasterd.'

Lam gaf als antwoord: 'Toen was ik nog niet geboren.' 
'Dan was het je vader die mij belasterd heeft,' zei Wolf, en greep het dier. Onschuldig is het toen verscheurd.

Deze fabel is geschreven met het oog op hen die valselijk onschuldigen vernietigen.

WOORDEN EN TOELICHTINGEN
$\begin{array}{ll}\text { 3. faux, faucis (sing.) } & \text { keel } \\ \text { 4. iurgium } & \text { ruzie } \\ \text { 10. } \text { male dicere } & \text { vervloeken } \\ \text { 13. corripere } & \text { beetpakken } \\ \quad \text { lacerare } & \text { verscheuren } \\ \text { 15. haec } & \text { te verbinden met fabula (hyperbaton) }\end{array}$

\subsection{Tempora invullen in een tekst}

Vul in de onderstaande passage uit Livius' verslag van de vroegste geschiedenis van Rome de juiste vormen van de tussen gebogen haakjes genoteerde infinitivi in. Het gaat met name om de keuze tussen imperfectum en perfectum. (Met [...] wordt aangegeven dat er een stukje tekst is weggelaten.)

(1) iam res Romana adeo (esse) valida ut cuilibet finitimarum civitatum bello par esset; sed penuria mulierum hominis aetatem magnitudo duratura erat; quippe quibus nec domi spes prolis nec cum finitimis conubia (esse). (2) tum ex consilio patrum Romulus legatos circa vicinas gentes (mittere), qui societatem conubiumque novo populo peterent. [...] (3) nusquam benigne legatio (audiri); adeo simul (spernere), simul tantam in medio crescentem molem sibi ac posteris suis (metuere). [...] (4) aegre id Romana pubes (pati), et haud dubie ad vim spectare res coepit.

(1) Rome was nu zo sterk dat zij in de oorlog opgewassen was tegen willekeurig welke buurstaat. Maar door een tekort aan vrouwen zag het er naar uit dat haar macht maar één generatie zou duren, omdat in de eigen stad geen hoop op nageslacht was en ook met de buren geen huwelijken konden worden aangegaan. (2) Toen stuurde Romulus op advies van de senaat gezanten rond naar de naburige stammen om een bondgenootschap met het recht van trouwen te vragen voor het nieuwe volk. [...] (3) Het gezantschap vond nergens een welwillend oor; niet alleen koesterden zij (nl. de naburige stammen) grote minachting, maar ook vreesden zij voor zichzelf en hun nakomelingen een zo grote macht die in hun midden bezig was te 
groeien. [...] (4) De jonge Romeinen konden dit maar moeilijk accepteren, en de zaak begon zo goed als zeker op geweld uit te lopen.

\section{TOELICHTINGEN}

3. simul ... simul: niet alleen ... maar ook subject van de adeo simul-zin zijn de genoemde vicinae gentes 



\section{Modus}

\subsection{Analyse van hoofdzinnen}

Vermeld het zinstype van onderstaande zinnen en de gebruikswijze van de gecursiveerde coniunctivusvormen. Geef ook een vertaling van de zinnen.

Voorbeeld: qui ad philosophum venit, cotidie aliquid secum boni ferat. (Sen. Ep. 108.4)

declaratief zinstype, potentialis

Wie naar een filosoof komt, kan dagelijks iets goeds mee terugnemen.

1. amemus patriam, pareamus senatui, consulamus bonis! (Cic. Sest. 142)

2. hae litterae te ne moverint. (Cic. Att. 16.1.6)

3. quid ego facerem? (Pl. Mer. 633)

4. forsitan et Priami fuerint quae fata requiras. (Verg. A. 2.506)

5. ubi invenias istum qui honorem amici anteponat suo? (Cic. Amic. 64)

6. si Catilina in urbe ad hanc diem remansisset, dimicandum nobis cum illo fuisset. (Cic. Catil. 3.17)

7. haec sint falsa sane, invidiosa certe non sunt. (cf. Cic. Acad. 105)

8. hoc sine ulla dubitatione confirmaverim. (Cic. Brut. 25)

9. sed ad rem redeamus! (cf. Cic. Fam. 2.10.1)

10. sit tibi terra levis. (bv. Mart. 9.29.11)

11. conquerar an sileam? (Ov. Met. 9.147)

12. hic mihi modus placet: temperetur vita inter bonos mores et publicos; suspiciant omnes vitam nostram sed agnoscant. (Sen. Ep. 5.5)

13. tempore crevit amor; taedae quoque iure coissent / sed vetuere patres. (Ov. Met. 4.60-61)

14. sit fur, sit sacrilegus, sit flagitiorum omnium vitiorumque princeps, at est bonus imperator. (Cic. Verr. 2.5.4) 


\section{WOORDEN EN TOELICHTINGEN}

$\begin{array}{ll}\text { 1. consulere, consulo + dat. } & \begin{array}{l}\text { zorgen voor } \\ \text { loyale burgers (politieke term) }\end{array} \\ \text { 2. litterae (plur.) } & \text { brief } \\ \text { 4. et (adverbium) } & \text { ook } \\ \text { Priami } & \text { genitivus, verbinden met quae fata } \\ \text { 6. dimicare } & \text { nochten } \\ \text { 7. haec } & \text { onwaar } \\ \text { falsus } & \text { verwerpelijk } \\ \text { invidiosus } & \text { bevestigen } \\ \text { 8. confirmare } & \text { klagen } \\ \text { 10. Dit is een traditioneel grafschrift. } \\ \text { 11. conqueri, conqueror } & \text { (levens)wijze } \\ \text { 12. modus } & \text { evenwichtig leiden } \\ \text { temperare } & \text { opkijken naar } \\ \text { suspicere, suspicio } & \text { erkennen, waarderen }\end{array}$

13. Deze versregels gaan over Piramus en Thisbe, een verliefd stel.
taeda
iure
huwelijksfakkel
vetuere
rechtmatig, wettig
= vetuerunt

14. sacrilegus

flagitium

heiligschenner

imperator

schanddaad

leider

\subsection{Modi invullen in hoofdzinnen}

Geef de juiste vorm van de tussen vierkante haken gegeven infinitivus en kijk daarbij goed naar de vertaling. Benoem de gekozen vorm en vermeld de gebruikswijze ervan.

1. si in Parthia natus esset, arcum infans statim [tendere]. (Sen. Ep. 36.7)

Als hij in Parthia was geboren, zou hij als kind meteen de boog spannen.

2. quid bella Tyro surgentia [dicere] / germanique minas? (Verg. $A$. 4.43-44)

Waarom moet ik de oorlogen, die in Tyrus oprijzen, noemen en de dreigingen van de kant van je broer? 
3. id [agere] ut meliorem vitam sequamur quam vulgus. (Sen. Ep. 5.3)

Laten wij ernaar streven dat wij beter leven dan het volk.

4. utinam minus vitae cupidi [esse]! (Cic. Fam. 14.4.1)

Ach, waren wij minder levenslustig geweest!

5. qua te regione [requirere]? (Ov. Met. 8.231)

In welk gebied moet ik je zoeken?

\section{TOELICHTINGEN}

1. Parthia is een landstreek ten zuiden van de Kaspische Zee.

2. Dido wordt hier toegesproken door haar zuster Anna.

Tyrus is de stad aan de Phoenicische kust waar Dido vandaan kwam.

\subsection{Analyse van bijzinnen}

Beschrijf het gebruik van de gecursiveerde modi in de onderstaande bijzinnen. Vertaal de zinnen.

voorbeeld: quin criminibus respondeam non recuso. (cf. Cic. Cael. 30.11)

respondeam: coniunctivus in argument-bijzin na verbum impediendi.

Ik weiger niet me te verdedigen tegen de beschuldigingen.

1. postulant ut signum detur. (Liv. 2.45.7)

2. Socrates cum facile educi e custodia posset noluit. (cf. Cic. Tusc. 1.71)

3. ne cum duobus exercitibus simul confligeret Hannibal nocte castra ex agro Tarentino movit. (Liv. 27.40.12)

4. quaeris quare te fuga ista non adiuvet? (Sen. Ep. 28.3)

5. tum enim bella gerere nostri duces incipiunt cum auspicia posuerunt. (Cic. N.D. 2.10)

6. restat ut qualis deorum natura sit consideremus. (cf. Cic. N.D. 2.45)

7. felix, heu nimium felix, si litora tantum / numquam Dardaniae tetigissent nostra carinae. (Verg. A. 4.657-658)

8. Aebutius cum tenere telum non posset pugna excessit. (Liv. 2.19.9)

9. interdicit omnibus ne quemquam interficiant. (cf. Caes. Gal. 7.40.4)

10. accidit perincommode quod eum nusquam vidisti. (Cic. Att. 1.17.2)

11. tangere enim et tangi nisi corpus nulla potest res, ut ait Lucretius. (Sen. Ep. 106.8) 
12. Verres Siciliam per triennium ita vexavit ut ea restitui in antiquum statum nullo modo possit. (cf. Cic. Verr. 1.12)

13. me caecum, qui haec ante non viderim! (Cic. Att. 10.10.1)

14. timor inde patres incessit ne rursus coetus occulti coniurationesque fierent. (Liv. 2.32.1)

15. si quis mihi parvulus aula / luderet Aeneas, qui te tamen ore referret, / non equidem omnino capta ac deserta viderer. (Verg. A. 4.328-330)

16. tu cavebis ne me attingas, si sapis. (Pl. Asin. 373)

17. tum Iuno omnipotens, longum miserata dolorem / difficilesque obitus, Irim demisit Olympo, / quae luctantem animam nexosque resolveret artus. (Verg. A. 4.693-695)

18. ${ }^{*}$ neque enim quisquam est tam aversus a Musis qui non mandari versibus aeternum suorum laborum praeconium facile patiatur. (Cic. Arch. 20)

19.* quid moror? an mea Pygmalion dum moenia frater / destruat? (Verg. A. 4.325-326)

20.* senatui placet ut consules monumentum quam amplissimum locandum faciendumque curent. (cf. Cic. Phil. 14.38)

\section{WOORDEN EN TOELICHTINGEN}

2. custodia

gevangenis

3. confligere, confligo in een gevecht verwikkeld raken ager Tarentinus het gebied rond Tarente (havenstad in Zuid-Italië)

4. adiuvare helpen, baten

5. auspicia (plur. neutr.) voortekens ponere

6. considerare raadplegen

7. Dido spreekt haar laatste woorden.

felix tantum (adverbium)

Dardanius

tangere, tetigi

carina

8. tenere, teneo

10. perincommode (adverbium) sc. fuissem maar, slechts Trojaans (Dardanus was de stamvader van de Trojanen) bereiken kiel, schip (pars pro toto) vasthouden zeer ongelegen

11. Lucretius (eerste helft eerste eeuw voor Chr.) was een Romeins dichter die de materialistische atoomtheorie van de Griekse filosoof Epicurus verkondigde. 
12. triennium vexare

periode van drie jaar

plunderen

14. incedere wordt hier verbonden met de accusativus: patres

patres

coetus, coetus

coniuratio, coniurationis

15. Dido spreekt tot Aeneas.

quis

aula

omnino (adverbium) senatoren

samenkomst

samenzwering

= aliquis, bijvoeglijk gebruikt

paleis

geheel en al, helemaal

17. Inno stuurt de bode Iris naar de aarde om Dido uit haar lijden te verlossen.

omnipotens

obitus, obitus

luctari

nectere, nexi, nexum

18. aversus a

mandare

praeconium

19. Dido is aan het woord.

morari

20. locare almachtig

het sterven

worstelen

vastknopen, vastbinden

afkerig van

toevertrouwen

lof(prijzing)

dralen

aanbesteden

\subsection{Analyse van een tekst}

Lees de onderstaande passage en de bijbehorende vertaling. Licht het modusgebruik toe van de gecursiveerde werkwoordsvormen. voorbeeld: (r. 1) fuit, indicativus perfectum in causale satelliet-bijzin (de reden wordt als een objectief feit gepresenteerd)

Cicero Pro Archia 19-20: In het voorafgaande heeft Cicero aan de orde gesteld dat veel steden in Klein-Azië en Griekenland vandaag de dag nog beweren dat Homerus hun burger was. Hij wijst er vervolgens op dat Archias heeft bijgedragen aan de roem van het Romeinse volk: in zijn dichtwerk heeft hij de bloedige oorlog met de Cimbren en Teutonen, die onder leiding van C. Marius in 102-101 werd gewonnen, vereeuwigd.

(1) ergo illi alienum, quia poeta fuit, post mortem etiam expetunt; nos hunc vivum, qui et voluntate et legibus noster est, repudiamus, praesertim cum omne olim studium atque omne ingenium contulerit Archias ad populi Romani gloriam laudemque celebrandam? (2) nam et Cimbricas res adulescens attigit et ipsi illi C. Mario, qui durior ad haec studia videbatur, iucundus fuit. (3) neque enim quis- 
quam est tam aversus a Musis qui non mandari versibus aeternum suorum laborum praeconium facile patiatur. (4) Themistoclem illum, summum Athenis virum, dixisse aiunt, cum ex eo quaereretur quod acroama aut cuius vocem libentissime audiret: eius a quo sua virtus optime praedicaretur. (5) itaque ille Marius item eximie L. Plotium dilexit, cuius ingenio putabat ea quae gesserat posse celebrari.

(1) Anderen claimen dus een vreemdeling, zelfs nog na zijn dood, omdat hij een dichter was; moeten wij hem hier dan afwijzen, die in leven is en naar eigen verlangen en op grond van de wet bij ons behoort, terwijl, let wel, Archias sinds lange tijd al zijn werkkracht en al zijn talent in dienst heeft gesteld van de verheerlijking van de roem en de glorie van het Romeinse volk? (2) De Cimbrische oorlogen, daar is hij in zijn jeugd aan begonnen en hij was geliefd zelfs bij Gaius Marius, die voor dergelijke literaire activiteiten geen al te grote sympathie leek te bezitten. (3) Niemand immers is zo afkerig van de Muzen dat hij de onvergankelijke lofzang op zijn daden niet aan de dichtkunst wil toevertrouwen. (4) Men vertelt dat toen Themistocles, een Atheense beroemdheid, gevraagd werd welke voordracht en welke stem hij het liefste hoorde, hij als antwoord gaf: de stem van diegene door wie zijn prestaties het beste werden geprezen. (5) Daarom was ook die beroemde Marius een groot liefhebber van Lucius Plotius, door wiens talent zijn verrichtingen volgens hem konden worden verheerlijkt.

\section{WOORDEN EN TOELICHTINGEN}

1. praesertim: vooral, temeer

4. Onder Themistocles' leiding behaalden de Grieken de overwinning in de slag bij Salamis (480).

acroama (Grieks leenwoord, neutrum): optreden, voordracht

5. Lucius Plotius was de oprichter van een beroemde redenaarsopleiding in Rome.

\subsection{Modi invullen in een tekst}

Lees de onderstaande passage en de bijbehorende inleiding en vertaling. Vul de ontbrekende werkwoordsvormen in (kijk goed naar de vertaling), benoem ze en licht je keuze toe.

Voorbeeld: r. 1 [debere] deberemus, coniunctivus imperfectum; uit de si-bijzin blijkt dat hier sprake is van een irrealis van het heden, dus ook coniunctivus irrealis van het heden in de bijbehorende hoofdzin. 
Cicero Pro Archia 17-18: Cicero gaat nader in op de waarde en het belang van literaire vorming en begaafdheid.

(1) quod si ipsi haec neque attingere neque sensu nostro gustare possemus, tamen ea mirari debere, etiam cum in aliis videremus. (2) quis nostrum tam animo agresti ac duro fuit ut Rosci morte nuper non [commoveri]? qui cum [esse] senex mortuus, tamen propter excellentem artem ac venustatem videbatur omnino mori non debuisse. (3) ergo ille corporis motu tantum amorem sibi conciliarat a nobis omnibus; nos animorum incredibilis motus celeritatemque ingeniorum neglegemus? (4) quotiens ego hunc Archiam vidi, iudices, - utar enim vestra benignitate, quoniam me in hoc novo genere dicendi tam diligenter attenditis - quotiens ego hunc vidi, cum litteram [scribere] nullam, magnum numerum optimorum versuum de eis ipsis rebus quae tum agerentur dicere ex tempore, quotiens revocatum eandem rem dicere commutatis verbis atque sententiis! (5) quae vero accurate cogitateque scripsisset, ea sic vidi probari ut ad veterum scriptorum laudem [pervenire]. (6) hunc ego non [diligere], non [admirari], non omni ratione defendendum [putare]?

(1) Ook als wij zelf niet in deze vorming konden delen en de smaak ervan niet konden proeven, zouden wij haar toch moeten bewonderen ook als wij haar slechts in anderen aanwezig zagen. (2) Wie van ons was zo onbeschaafd en afgestompt dat hij onlangs niet door de dood van Roscius werd ontroerd, een man die, hoewel op hoge leeftijd gestorven, omwille van zijn uitnemende bekwaamheid en charme nooit had mogen sterven. (3) Door de beweging van zijn lichaam had hij zo'n grote geliefdheid bij ons allen verworven: zullen wij dan de wonderbaarlijke beweeglijkheid van de geest en de snelheid van het menselijk denken minachten? (4) Dikwijls heb ik Archias gezien, heren juryleden - ik maak van uw instemming gebruik omdat $\mathrm{u}$ zo aandachtig naar mij luistert bij dit ongebruikelijke pleidooi -, dikwijls heb ik gezien hoe Archias, ook al had hij geen woord opgeschreven, een groot aantal prachtige verzen over actuele gebeurtenissen improviseerde, hoe hij, teruggeroepen, hetzelfde onderwerp bezong met andere woorden en denkbeelden! (5) Wat hij echter met veel zorg en voorbereiding had neergeschreven, vond - naar ik zag - zoveel erkenning dat hij de roem van de klassieke schrijvers evenaarde. (6) Moet ik deze man dan niet beminnen, bewonderen, het niet tot mijn plicht achten hem hoe dan ook te verdedigen? 


\section{TOELICHTINGEN}

2. Quintus Roscius Gallus, de beroemdste toneelspeler uit die tijd; door Sulla in de ridderstand opgenomen.

3. conciliarat $=$ conciliaverat

\section{6* Modi invullen in een tekst}

Lees de onderstaande passage en de bijbehorende inleiding en vertaling. Vul de ontbrekende werkwoordsvormen in (kijk goed naar de vertaling), benoem ze en licht je keuze toe. Een voorbeeld wordt gegeven in de instructie bij opdracht 7.5.

Livius 2.34.7-12: In 491 voor Chr. heerst er hongersnood in Rome. Er worden mannen uitgezonden om elders, zelfs in Zuid-Italië en Sicilië, graan te gaan kopen. Een aantal senatoren wil gebruikmaken van de noodsituatie en de plebejers een deel van hun rechten ontnemen. Een van hen is Coriolanus, die zijn afkeer van de tribunicia potestas (de bevoegdheden van de volkstribunen) verwoordt in een redevoering.

(1) M. Minucio deinde et A. Sempronio consulibus magna vis frumenti ex Sicilia advecta, agitatumque in senatu quanti plebi [dari]. (2) multi venisse tempus premendae plebis putabant reciperandique iura quae extorta secessione ac vi patribus essent. (3) in primis Marcius Coriolanus, hostis tribuniciae potestatis, 'si annonam,' inquit, 'veterem volunt, ius pristinum [reddere] patribus. (4) cur ego plebeios magistratus, cur Sicinium potentem video, sub iugum missus, tamquam ab latronibus redemptus? (5) egone has indignitates diutius [pati] quam necesse est? (6) Tarquinium regem qui non tulerim, Sicinium [ferre]? (7) [secedere] nunc; [avocare] plebem; patet via in Sacrum montem aliosque colles; [rapere] frumenta ex agris nostris, quemadmodum tertio anno rapuerunt. (8) [frui] annona quam furore suo fecerunt. (9) audeo dicere hoc malo domitos ipsos potius cultores agrorum fore quam ut armati per secessionem coli prohibeant.'

(1) Tijdens het consulaat van Marcus Minucius en Aulus Sempronius arriveerde een grote hoeveelheid graan uit Sicilië en in de senaat werd gedebatteerd over de prijs die het plebs ervoor zou moeten betalen. (2) Velen waren van mening dat het moment was aangebroken om het volk weer klein te krijgen en de rechten terug te winnen die door afscheiding en geweld aan de senatoren waren ontfutseld. (3) Het hoogste woord had Marcius Coriolanus, vijand 
van de tribunische bevoegdheid: 'Als ze de oude graanprijs willen, moeten zij aan de senatoren hun oude rechten teruggeven. (4) Waarom zie ik plebejische magistraten, een machtige Sicinius? Ik voel me onder het juk gezonden en uit rovershanden vrijgekocht. (5) Moet ik deze vernederingen langer verduren dan nodig is? (6) Koning Tarquinius heb ik niet verdragen, moet ik dan Sicinius verdragen? (7) Laat hij zich nu maar afscheiden, het volk wegroepen; de weg naar de Heilige Berg en de rest van de heuvels ligt open. Laten ze het graan maar plunderen van onze akkers zoals ze twee jaar geleden deden; (8) laten ze genieten van een graanprijs die ze door hun eigen waanzin hebben bepaald. (9) Ik durf te zeggen dat zij onder de druk van deze noodtoestand liever zelf landarbeiders zullen worden dan gewapend door een afscheiding de landarbeid verhinderen.'

\section{TOELICHTINGEN}

1. advecta en agitatum: advecta est en agitatum est

4. Sicinius nam het initiatief tot de secessio plebis.

\section{7* Modi invullen in een tekst}

Lees de onderstaande passage en de bijbehorende inleiding en vertaling. Vul de ontbrekende werkwoordsvormen in (kijk goed naar de vertaling), benoem ze en licht je keuze toe. Een voorbeeld wordt gegeven in de instructie bij opdracht 7.5.

Livius 2.40.1-6: In 488 voor Chr. belegeren de Volscen Rome. Hun aanvoerders zijn Attius Tullius en Coriolanus, die na een conflict met de senaat in ballingschap leefde bij de Volscen. De Romeinen proberen te onderhandelen met Coriolanus, maar die stelt harde voorwaarden: hij wil alleen onderhandelen als de Romeinen het gebied zouden teruggeven dat ze de Volscen ontnomen hadden. Dan proberen de Romeinse matronen de impasse te doorbreken.

(1) tum matronae ad Veturiam matrem Coriolani Volumniamque uxorem frequentes coeunt. (2) id publicum consilium an muliebris timor [esse], parum invenio; pervicere certe, ut et Veturia, magno natu mulier, et Volumnia duos parvos ex Marcio ferens filios secum in castra hostium [ire] et, quoniam armis viri defendere urbem non possent, mulieres precibus lacrimisque [defendere]. (3) ubi ad castra ventum est nuntiatumque Coriolano est adesse ingens mulierum agmen, ut qui nec publica maiestate in legatis nec in sacerdotibus 
tanta offusa oculis animoque religione motus esset, multo obstinatior adversus lacrimas muliebres erat. (4) Dein familiarium quidam qui insignem maestitia inter ceteras cognoverat Veturiam, inter nurum nepotesque stantem, 'nisi me frustrantur', inquit, 'oculi, mater tibi coniunxque et liberi adsunt.' (5) Coriolanus prope ut amens consternatus ab sede sua cum ferret matri obviae complexum, mulier in iram ex precibus versa 'sine ut, priusquam complexum accipio, [scire]', inquit, 'ad hostem an ad filium [venire], captiva materne in castris tuis [esse]. (6) in hoc me longa vita et infelix senecta traxit ut exsulem te deinde hostem [videre]?'

(1) Toen kwamen de gehuwde vrouwen in groten getale tezamen bij Veturia, de moeder van Coriolanus, en zijn echtgenote Volumnia. (2) Of hier sprake is geweest van een politiek plan of van angst van vrouwen, kan ik niet precies nagaan; in elk geval hebben zij weten te bereiken dat Veturia, een oude vrouw, en Volumnia met haar twee kinderen van Marcus naar het vijandelijke kamp gingen en omdat de mannen de stad niet met de wapens konden verdedigen, de vrouwen dit met smeekbeden en tranen zouden proberen. (3) Toen men bij het kamp was gearriveerd, werd de komst van een grote stoet vrouwen aan Coriolanus gemeld. Hij die toch al niet onder de indruk was geweest van de officiële waardigheid van gezanten en de oog en hart beroerende heiligheid van priesters, was nog veel stijfkoppiger tegenover vrouwentranen. (4) Een van zijn vrienden, die door het opmerkelijk vertoon van droefheid te midden van de overige vrouwen Veturia had ontdekt, staande tussen haar schoondochter en kleinkinderen, zei: 'Als mijn ogen mij niet bedriegen, staan daar je moeder en je vrouw en kinderen.' (5) Ontsteld sprong Coriolanus op uit zijn zetel en wilde zijn moeder omhelzen, maar haar smeekbede sloeg om in woede en zij zei: 'Laat me eerst weten, voor ik jouw omhelzing accepteer, of ik bij een vijand of bij mijn zoon ben gekomen, of ik in jouw kamp een krijgsgevangene of je moeder ben. (6) Hebben mijn lange leven en ongelukkige ouderdom mij hiertoe gesleept dat ik jou in ballingschap moest zien en vervolgens als vijand?'

TOELICHTING

2. pervicere $=$ pervicerunt 


\section{Vraagzinnen}

\subsection{Invuloefening}

Vul in de onderstaande zinnen het juiste vraagwoord in en de juiste werkwoordsvorm, of alleen de juiste werkwoordsvorm. Kijk daarbij goed naar de vertaling.

1. [...] huic rei testis [esse]? (Cic. Quinct. 37) Wie is de getuige in deze zaak?

2. [...] [esse] aut [...] [velle], quaesivit. (Caes. Gal. 2.35.2) Hij vroeg wie hij was en wat hij wilde.

3. non interrogabo illos, [...] figuram [habere] ista animalia. (Sen. Ep. 113.22)

Ik zal hun niet vragen welke vorm die wezens hebben.

4. [...] tibi videtur stultissimus omnium, qui flevit quod ante annos mille non vixerat? (Sen. Ep. 77.11)

Jij vindt hem toch zeker allerdwaast, die huilde omdat hij duizend jaar geleden niet geleefd had?

5. [...] me [vertere], nescio. (Cic. Lig. 1)

Waarheen ik moet vluchten, weet ik niet.

6. requisivit, [...] apud Germanos pudor atque officium [...] timor plus [valere]. (cf. Caes. Gal. 1.40.14)

Hij wilde weten of bij de Germanen eergevoel en plicht of angst de overhand hadden.

7. [...] quis in Verrem L. Metelli testimonium [requirere]? Nemo. (Cic. Verr. 2.3.123)

Verlangt soms iemand het getuigenis van Lucius Metellus tegen Verres? Niemand.

8. videamus primum, deorum[...] providentia mundus [regere]. (Cic. N.D. 3.65)

Laten wij eerst bekijken of de wereld wordt bestuurd door de voorzienigheid van de goden. 
9. deliberandum est, [...] aliquid honestum [...] turpe [esse]. (Cic. Off. 1.10)

Er moet over gediscussieerd worden of iets eerbaar of schandelijk is.

10. poetae [...] post mortem nobilitari volunt? (Cic. Tusc. 1.34)

Willen dichters dan niet na hun dood beroemd worden?

\subsection{Invuloefening}

Vul in de onderstaande zinnen uit Vergilius' Aeneis het juiste vraagwoord in en de juiste werkwoordsvorm. Kijk daarbij goed naar de vertaling en houd rekening met de versmaat.

1. [...] genus Aeneadum, [...] Troiae [nescire] urbem? (A. 1.565)

Wie zou het volk van de nakomelingen van Aeneas, wie de stad Troje niet kennen?

2. [eloqui] [...] [silere]? (A. 3.39) NB Dit is het begin (de eerste tweeenhalve versvoet) van de hexameter!

Moet ik spreken of zwijgen?

3.* placito [...] etiam pugnabis amori / nec venit in mentem [...] [considere] arvis? (A. 4.38-39, Anna spreekt tot haar zuster Dido) Zul jij zelfs een welkome liefde bestrijden / en denk je er niet aan in wier gebied je je gevestigd hebt?

4. ${ }^{*}$ infelix Dido longumque bibebat amorem, / multa super Priamo rogitans, super Hectore multa; / nunc [...] Aurorae [venire] filius armis. (A. 1.749-751)

En de onfortuinlijke Dido raakte beneveld door intense verliefdheid, / en zij vroeg veel over Priamus, veel over Hector, / dan weer met welke wapens de zoon van Aurora was gekomen. 


\section{Oratio obliqua}

\subsection{Oratio recta en obliqua, zinnen omzetten}

Zet de oratio recta om in oratio obliqua en vertaal de omgezette zinnen.

1. centurio dixit: 'fortiter pugnavistis.'

2. Caesar exclamavit: 'mittite ad me legatos.'

3. Pompeius respondit: 'ne dubitaveritis pugnare.'

4. praetor dixit: 'postquam Romam veni, consulatum petivi.'

5. rex narravit: 'legati mihi liberisque vitam petiverunt.'

6. philosophus rogavit: 'quid est turpius quam patriam prodere?'

7. Cicero scripsit: 'iam diu inter Romanos Saguntinosque amicitia est; cuius neutros ad id tempus paenitet.'

8. mater rogavit: 'cur mentitus es?'

9. Octavianus rogavit: 'ubi castra ponam?'

10. servi rogaverunt: 'num possumus oblivisci iniuriarum vestrarum?'

\section{2* Oratio recta en obliqua, omzetten van een tekst}

Zet het tekstfragment dat in oratio recta is gesteld om in oratio obliqua.

We schrijuen het jaar 58 voor Chr. Caesar voert strijd tegen de Helvetiërs. In Diviacus, de pro-Romeinse hoofdman van de Haeduers (een machtig Keltisch volk in Midden-Frankrijk) heeft hij een bondgenoot. Maar diens broer Dumnorix, die anti-Romeins gezind is en populair bij de Haeduers, heeft de Helvetiërs gesteund tegen de Romeinen. Caesar wil Dumnorix straffen, maar voordat hij iets onderneemt, spreekt hij eerst met Diviacus over zijn plannen. 
Diviacus multis cum lacrimis Caesarem complexus obsecrare coepit, ne quid gravius in fratrem statueret:

'scio illa esse vera neque quisquam ex eo plus quam ego doloris capit, propterea quod, cum ego ipse gratia* plurimum domi atque in reliqua Gallia possem, ille minimum propter adulescentiam, per me crevit, quibus opibus ac nervis** non solum ad minuendam gratiam sed paene ad perniciem meam utebatur. ego tamen et amore fraterno et existimatione vulgi commoveor. quod si quid ei a te gravius accidit, cum ipse eum locum amicitiae apud te teneam, nemo existimabit non mea voluntate factum; qua ex re fiet uti totius Galliae animi a me avertantur.'

* gratia: ablativus

** quibus opibus ac nervis: relativum met ingesloten antecedent

*** gebruik bij de omzetting van te geen persoonlijk voornaamwoord, maar de naam Caesar

Onder een stroom van tranen omarmde Diviacus Caesar en vroeg hem dringend toch geen al te zware maatregelen tegen zijn broer te nemen:

'Ik weet dat het waar is en niemand heeft daar meer verdriet van dan ik, omdat, toen ik zelf in mijn eigen streek en in de rest van Gallië zeer veel invloed bezat, en hij heel weinig vanwege zijn jeugdige leeftijd, hij dankzij mij is gegroeid in kracht en macht die hij niet alleen gebruikte om mijn invloed te verkleinen, maar om mij zo ongeveer te vernietigen. Toch word ik door broederliefde en de publieke opinie niet onberoerd gelaten. Als hem evenwel van uw kant iets ernstigs is overkomen, terwijl ik zo'n vriendschappelijke positie bij $\mathrm{u}$ inneem, zal niemand denken dat dit zonder mijn instemming is gebeurd; dan zal het gevolg zijn dat de gevoelens van geheel Gallië zich van mij afkeren.' 


\section{Tekstsamenhang}

\section{Analyse van een tekst}

Lees de onderstaande brief van Plinius (7.27) en de bijbehorende inleiding en vertaling. Beantwoord daarna de vijf vragen.

\section{Inleiding}

Onderstaande 'kunstbrief' van Plinius Minor (c. 61-114) heeft een tamelijk transparante macrostructuur, waarin drie narratieve episoden zijn 'ingeklemd' tussen een betogende proloog en epiloog. De samenstellende onderdelen worden steeds door een overgangszin van elkaar gescheiden. De drie narratieve episoden, die van nogal ongelijke lengte zijn, vormen ieder op zich een narratieve ondersteuning van de in de proloog door de schrijver geformuleerde stelling credo esse [phantasmata], 'Ik ben van mening dat spoken bestaan.' In de proloog wordt de adressaat van de brief, Sura, uitgenodigd op Plinius' stelling en argumentatie te reageren. In de epiloog wordt deze uitnodiging herhaald, waardoor een ringcompositie ontstaat.

1. Bespreek het tijdgebruik in de hoofdzinnen van $\S 2$ (de eerste narratieve episode, na de overgangszin) en het effect van de gekozen tijden voor de structuur van deze paragraaf.

2. Verklaar in de tweede narratieve episode de overgang van het gebruik van (hoofdzakelijk) imperfecta (in § 5-6) naar het gebruik van (hoofdzakelijk) historische praesentia (vanaf $\S 7$ tot het eind van de episode).

3. In de tweede narratieve episode wordt voor de voortgang van de hoofdlijn van het verhaal in hoofdzinnen gebruikgemaakt van het praesens historicum, in afwisseling met de infinitivus historicus. De hele episode kent slechts één niet-ambigue perfectumvorm in een hoofdzin. Om welke vorm gaat het? En waarom lijkt het praesens historicum in deze zin geen goed alternatief te zijn? 
4. Verklaar de woordvolgorde in de eerste zin van $\S 5$. Welke zin in deze tweede narratieve episode heeft een vergelijkbare woordvolgorde?

5. Verklaar waarom in $\S 8$ het anaforisch pronomen ille (ille non tollere oculos) gebruikt wordt, en niet bijvoorbeeld is, zoals in $\S 12$ (is visus est sibi cernere quendam in toro residentem).

Plinius Epistula 7.27

C. Plinius Surae suo salutem dicit

proloog

1 et mihi discendi et tibi docendi facultatem otium praebet. igitur perquam velim scire, esse phantasmata et habere propriam figuram numenque aliquod putes an inania et vana ex metu nostro imaginem accipere.

overgangszin

2 ego ut esse credam in primis eo ducor, quod audio accidisse Curtio Rufo.

\section{narratieve episode 1}

tenuis adhuc et obscurus, obtinenti Africam comes haeserat. inclinato die spatiabatur in porticu; offertur ei mulieris figura humana grandior pulchriorque. perterrito Africam se futurorum praenuntiam dixit: iturum enim Romam honoresque gesturum, atque etiam cum summo imperio in eandem provinciam reversurum, ibique moriturum. facta sunt omnia.

3 praeterea accedenti Carthaginem egredientique nave eadem figura in litore occurrisse narratur. ipse certe implicitus morbo futura praeteritis, adversa secundis auguratus, spem salutis nullo suorum desperante proiecit.

overgangszin

4 iam illud nonne et magis terribile et non minus mirum est quod exponam ut accepi?

narratieve episode 2

5 erat Athenis spatiosa et capax domus sed infamis et pestilens. per silentium noctis sonus ferri, et si attenderes acrius, strepitus vinculorum longius primo, deinde e proximo reddebatur: mox adparebat idolon, senex macie et squalore confectus, promissa barba horrenti capillo; cruribus compedes, manibus catenas gerebat quatiebatque. 
6 inde inhabitantibus tristes diraeque noctes per metum vigilabantur; vigiliam morbus et crescente formidine mors sequebatur. nam interdiu quoque, quamquam abscesserat imago, memoria imaginis oculis inerrabat, longiorque causis timoris timor erat. deserta inde et damnata solitudine domus totaque illi monstro relicta; proscribebatur tamen, seu quis emere seu quis conducere ignarus tanti mali vellet.

7 venit Athenas philosophus Athenodorus, legit titulum auditoque pretio, quia suspecta vilitas, percunctatus omnia docetur ac nihilo minus, immo tanto magis conducit. ubi coepit advesperascere, iubet sterni sibi in prima domus parte, poscit pugillares stilum lumen, suos omnes in interiora dimittit; ipse ad scribendum animum oculos manum intendit, ne vacua mens audita simulacra et inanes sibi metus fingeret.

8 initio, quale ubique, silentium noctis; dein concuti ferrum, vincula moveri. ille non tollere oculos, non remittere stilum, sed offirmare animum auribusque praetendere. tum crebrescere fragor, adventare et iam ut in limine, iam ut intra limen audiri. respicit, videt agnoscitque narratam sibi effigiem.

9 stabat innuebatque digito similis vocanti. hic contra ut paulum exspectaret manu significat rursusque ceris et stilo incumbit. illa scribentis capiti catenis insonabat. respicit rursus idem quod prius innuentem, nec moratus tollit lumen et sequitur.

10 ibat illa lento gradu quasi gravis vinculis. postquam deflexit in aream domus, repente dilapsa deserit comitem. desertus herbas et folia concerpta signum loco ponit.

11 postero die adit magistratus, monet ut illum locum effodi iubeant. inveniuntur ossa inserta catenis et implicita, quae corpus aevo terraque putrefactum nuda et exesa reliquerat vinculis; collecta publice sepeliuntur. domus postea rite conditis manibus caruit.

overgangszin

12 et haec quidem adfirmantibus credo; illud adfirmare aliis possum:

narratieve episode 3

est libertus mihi non inlitteratus. cum hoc minor frater eodem lecto quiescebat. is visus est sibi cernere quendam in toro residentem, admoventemque capiti suo cultros, atque etiam ex ipso vertice amputantem capillos. ubi inluxit, ipse circa verticem tonsus, capilli iacentes reperiuntur.

13 exiguum temporis medium, et rursus simile aliud priori fidem fecit. puer in paedagogio mixtus pluribus dormiebat. venerunt 
per fenestras ita narrat in tunicis albis duo cubantemque detonderunt et qua venerant recesserunt. hunc quoque tonsum sparsosque circa capillos dies ostendit.

14 nihil notabile secutum, nisi forte quod non fui reus, futurus, si Domitianus sub quo haec acciderunt diutius vixisset. nam in scrinio eius datus a Caro de me libellus inventus est; ex quo coniectari potest, quia reis moris est summittere capillum, recisos meorum capillos depulsi quod imminebat periculi signum fuisse.

epiloog

15 proinde rogo, eruditionem tuam intendas. digna res est quam diu multumque consideres; ne ego quidem indignus, cui copiam scientiae tuae facias.

16 licet etiam utramque in partem ut soles disputes, ex altera tamen fortius, ne me suspensum incertumque dimittas, cum mihi consulendi causa fuerit, ut dubitare desinerem. vale.

\section{Vertaling}

proloog

1 Vrije tijd geeft mij gelegenheid om te leren en jou om te onderwijzen. Welnu, ik zou graag willen weten of jij denkt dat er spoken bestaan met een eigen gestalte en een bepaalde macht, of dat zij niet werkelijk bestaan en door onze angst gestalte krijgen.

overgangszin

2 Mijn geloof in hun bestaan wordt allereerst veroorzaakt door wat, naar ik hoor, Curtius Rufus is overkomen.

\section{narratieve episode 1}

Toen hij nog geen aanzien en bekendheid genoot, was hij lid van de staf geweest van de gouverneur van Afrika. Tegen de avond wandelde hij in een zuilengalerij. Voor zijn ogen verscheen een vrouwelijke gestalte, bovenmenselijk groot en mooi, die hem zeer deed schrikken. Zij zei tegen hem dat zij Afrika was en de toekomst kwam voorspellen: hij zou naar Rome gaan, politiek carrière maken, en zelfs met het hoogste gezag bekleed naar deze provincie terugkeren en er sterven. Alles is uitgekomen.

3 Bovendien vertelt men dat toen hij in Carthago arriveerde en voet aan wal zette, dezelfde vrouw hem op de kust tegemoet gerend is. Zeker is dat hij, ziek geworden, uit de voorbije voorspoed de naderende tegenspoed afleidde, de hoop op herstel liet varen zonder dat iemand uit zijn omgeving wanhoopte. 
overgangszin

4 Maar wat ik nu ga vertellen zoals ik het heb gehoord, is dat niet nog enger en even wonderlijk?

narratieve episode 2

5 Er stond in Athene een groot, ruim huis, maar berucht en ongelukbrengend. In de nachtelijke stilte klonk geluid en als je scherper luisterde, hoorde je gerinkel van kettingen, eerst verder weg en vervolgens van dichtbij en dan verscheen de gestalte van een oude man, mager en smerig, met een lange baard en ruige haardos. Aan zijn benen droeg hij boeien, aan zijn handen kettingen waarmee hij schudde.

6 Sindsdien brachten de bewoners uit angst afschuwelijk enge nachten slapeloos door; de slapeloosheid leidde tot ziekte en met het groeien van de angst tot hun dood. Want ook bij dag, al was de verschijning verdwenen, spookte de herinnering eraan voor hun ogen, de angst duurde langer dan zijn oorzaken. Het huis was sindsdien verlaten, tot eenzaamheid gedoemd en geheel aan die spookverschijning prijsgegeven. Toch werd het aangeboden, te koop of te huur, voor een eventuele klant, onbekend met de grote ellende.

7 Nu kwam naar Athene de filosoof Athenodorus, hij las de aanbieding en toen hij na het horen van de prijs, die verdacht laag was, verder navraag deed, hoorde hij de hele toedracht en niettemin, of liever des te meer huurde hij het. Toen het avond begon te worden, liet hij in het eerste deel van het huis een bed opmaken en vroeg een schrijftafeltje, schrijfstift en een lamp. Al zijn huisgenoten stuurde hij weer naar binnen, zelf richtte hij zijn aandacht, ogen en hand op zijn schrijfwerk. Hij wilde vermijden dat zijn geest in ledigheid geluidmakende verschijningen en irreële angstvoorstellingen zou creëren.

8 Aanvankelijk heerste, zoals overal, de stilte van de nacht, daarna volgde geschud van ijzer, beweging van boeien. Hij hief zijn ogen niet op, legde zijn schrijfstift niet neer, maar vermande zijn geest tot een muur voor zijn oren. Toen vermeerderde het lawaai, kwam nader en werd soms op de drempel, soms binnen de drempel gehoord. Hij kijkt om, ziet en herkent de gestalte waarvan men hem verteld had.

9 Daar stond hij wenkend met zijn vinger alsof hij riep. De ander daarentegen gebaarde dat hij even moest wachten, en boog zich weer over schrijftafel en stift. Terwijl hij schreef rammelde de verschijning met de kettingen boven zijn hoofd. Hij kijkt om, ziet hem weer wenken en zonder aarzelen pakt hij de lamp en volgt hem. 
10 Daar liep het spook met slepende passen alsof het door de boeien werd gehinderd. Nadat het was afgebogen naar de binnenplaats van het huis, loste het plotseling op en liet zijn metgezel alleen achter, die wat gras en bladeren verzamelde om de plek te markeren.

11 De volgende dag ging hij naar het stadsbestuur en drong erop aan dat ze die plek zouden laten uitgraven. Er werden beenderen gevonden, vastzittend en verstrikt in kettingen; het lichaam, dat op den duur tot stof was vergaan, had de botten achtergelaten, kaal en aangevreten door de boeien. $\mathrm{Zij}$ werden verzameld en op staatskosten begraven. Door de passende begrafenis is het huis van de schim bevrijd.

overgangszin

12 Ik geloof degenen die dit met klem vertellen; zelf kan ik anderen het volgende verzekeren.

\section{narratieve episode 3}

Ik heb een vrijgelatene die niet ongeletterd is. Zijn jongere broer sliep met hem in hetzelfde bed. Hij droomde dat hij iemand op het bed zag zitten die een mes naar zijn hoofd bracht en vanaf de kruin zijn haren afsneed. Toen het licht was geworden, bleek zijn kruin kaalgeschoren en lagen de haren op de grond.

13 Een korte tijd verstreek en iets vergelijkbaars deed zich voor dat het eerste voorval bevestigde. Een jonge slaaf sliep samen met anderen in hun verblijf; twee mannen in witte tuniek (zo vertelt hij) kwamen door het raam naar binnen, schoren hem kaal terwijl hij daar lag, en verdwenen weer langs dezelfde weg. Ook hij bleek de volgende dag kaalgeschoren en de haren lagen verspreid in het rond.

14 Niets opmerkelijks volgde behalve dat ik niet werd aangeklaagd, wat gebeurd zou zijn als Domitianus, die toen keizer was, langer had geleefd. Want in zijn bureau is een aanklacht aangetroffen die door Carus tegen mij was opgesteld. Dit feit leidt tot de volgende verklaring: omdat het gebruikelijk is dat aangeklaagden hun haar laten groeien, is het afknippen van de haren van mijn slaven een teken geweest dat het dreigende gevaar van een proces was verijdeld.

epiloog

15 Ik vraag je dus je geleerdheid in te zetten. De zaak verdient je volle en langdurige aandacht en ik zelf verdien dat je me in je kennis laat delen. 
16 Ook als je de zaak zoals gewoonlijk van twee kanten wilt bekijken, laat dan duidelijk je voorkeur blijken zodat je me niet in spanning en onzekerheid laat, aangezien ik je juist wilde raadplegen om aan mijn twijfel een einde te maken. Het allerbeste. 



\section{Uitwerkingen}

\section{Hoofdstuk 1, Grammaticale analyse}

\section{Oefening 1.1}

1. De goden zijn vroomheid gunstig gezind. favent

predicaat

dei argument, subject

pietati argument, complement

2. Verneem wat de jongen hierop antwoordde.
accipe
quid contra haec iuvenis responderit
predicaat
INGEBEDDE PREDICATIE (AFHANKELIJKE VRAAG)
responderit
predicaat
iuvenis
argument, subject
quid
argument, object
contra haec
satelliet, adjunct

3. Wij zien bij zonsopgang dat een bepaald deel van de hemel rood is.

videmus

ortu solis

NOMINALE GROEP
ortu
solis

partem quandam caeli rubere

INGEBEDDE PREDICATIE (A.C.I.)

rubere

partem quandam caeli

NOMINALE GROEP

partem

quandam

caeli predicaat (+ eerste

argument, subject)

satelliet, adjunct

hoofd

attribuut

argument, object

predicaat

argument, subject

hoofd

attribuut

attribuut 
4. Maak een einde aan dit leven en verlos mij uit dit lijden. TWEE GECOÖRDINEERDE HOOFDZINNEN (-QUE: COÖRDINATOR) accipite hanc animam predicaat NOMINALE GROEP animam argument, object

animam
hanc

exsolvite

$$
\text { argument, object }
$$

me

his curis

hoofd

attribuut

predicaat

argument, object

argument,

complement

NOMINALE GROEP

curis

hoofd

his

attribuut

5. Ik verkies de dood boven de slavernij.
antepono
predicaat (+ eerste
argument, subject)
mortem
argument, object
servituti
argument,
complement

6. Hij vliegt door de duisternis zonder dat zijn vleugels lawaai maken.

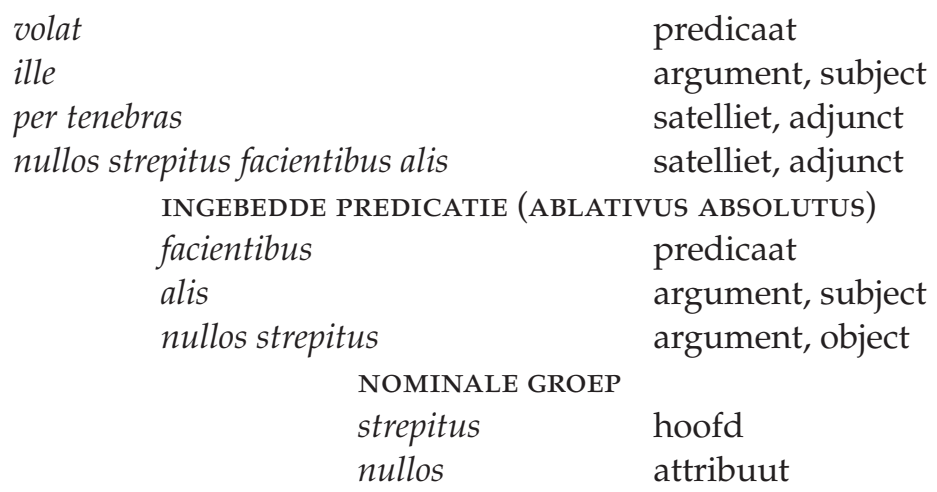

7. Terwijl dit gebeurde bij de Veneti, bereikte Quintus Titurius Sabinus met die troepen, die hij van Caesar had meegekregen, het gebied van de Unelli.
pervenit
predicaat
Q. Titurius Sabinus
argument, subject
in fines Unellorum
argument,
complement 
NOMINALE GROEP

fines

Unellorum

dum haec in Venetis geruntur

INGEBEDDE PREDICATIE

geruntur

haec

in Venetis

cum iis copiis, quas a Caesare acceperat

NOMINALE GROEP

copiis

iis

quas a Caesare acceperat hoofd

attribuut

satelliet, adjunct

predicaat

argument, subject

satelliet, adjunct

satelliet, adjunct

hoofd

attribuut

attribuut

INGEBEDDE PREDICATIE (RELATIEVE BIJZIN)

acceperat

predicaat (+ eerste

argument, subject)

quas argument, object

a Caesare argument,

complement

8. Ze stuurden gezanten naar de Haeduer Dumnorix om op zijn voorspraak toestemming te krijgen van de Sequanen ( $\mathrm{nl}$. om door hun gebied te trekken).

mittunt

legatos

ad Dumnorigem Aeduum

ut eo deprecatore a Sequanis impetrarent

INGEBEDDE PREDICATIE (FINALE UT-BIJZIN)

impetrarent

a Sequanis

eo deprecatore predicaat (+ eerste argument, subject) argument, object argument, complement of satelliet, adjunct satelliet, adjunct predicaat (+ eerste en tweede argument: subject en object) argument, complement satelliet, adjunct

INGEBEDDE PREDICATIE (ABL. ABS.)

deprecatore predicaat

eo argument, subject

9. Niemand doet moeite zijn hebzucht verborgen te laten lijken.

laborat

nemo predicaat

argument, subject 
ut obscura sua cupiditas esse videatur

INGEBEDDE PREDICATIE

obscura esse videatur

sua cupiditas

NOMINALE GROEP

cupiditas

sua argument, complement

of satelliet, adjunct

predicaat (obscura:

predicaatsnomen)

argument, subject

hoofd

attribuut

10. Uit vrees dat zij (nl. Eurydice) achter zou blijven en begerig haar te zien, keek hij liefdevol om.
flexit
predicaat
hic
argument, subject
oculos
metuens ne deficeret
argument, object
eerste satelliet,
adjunct: predicativum
INGEBEDDE PREDICATIE
metuens
predicaat (+ eerste
argument, subject)
ne deficeret
argument, complement

INGEBEDDE PREDICATIE

deficeret

predicaat (+ eerste

avidus videndi

argument, subject)

tweede satelliet,

adjunct: predicativum

INGEBEDDE PREDICATIE

avidus

predicaat (+ eerste

argument, subject)

videndi

argument, complement

(gerundium)

INGEBEDDE PREDICATIE

videndi

predicaat (+ eerste en

tweede argument,

subject en object)

amans

derde satelliet, adjunct: predicativum

INGEBEDDE PREDICATIE

amans

predicaat (+ eerste en tweede argument, subject en object) 


\section{Oefening 1.2}

1. nam, r. 1 ; nam, r. 3

2. atque, r. 1 ; et, r. 4 ; atque, r. 4 ; -que, r. 5; -que, r. 7 ; -que, r. 9

3. ut primum, r. 1 ; ut, r. 7

4 .

ut primum ex pueris excessit Archias atque ab eis artibus quibus aetas puerilis ad humanitatem informari solet, se ad scribendi studium contulit, primum Antiochiae celeriter antecellere omnibus ingeni gloria coepit.

\section{niveau 1}

antecellere coepit

omnibus

predicaat (+ eerste argument, subject)

ut primum $\mathrm{t} / \mathrm{m}$ contulit

argument, complement

primum satelliet, adjunct (+ ingebedde predicatie niveau 2)

Antiochiae

satelliet, adjunct

celeriter satelliet, adjunct

ingeni gloria satelliet, adjunct satelliet, adjunct

NOMINALE GROEP

gloria hoofd

ingeni attribuut

\section{niveau 2: tweeledige ingebedde predicatie (coördinator: atque)}

ut primum ex pueris excessit Archias atque ab eis artibus quibus aetas puerilis ad humanitatem informari solet, se ad scribendi studium contulit A.

excessit
Archias
ex pueris
B.
contulit
se
ad scribendi studium
$\quad$ NOMINALE GROEP
studium
scribendi
ab eis artibus $\mathrm{t} / \mathrm{m}$ solet
$\quad$ NOMINALE GROEP
artibus
eis
quibus $\mathrm{t} / \mathrm{m}$ solet

predicaat

argument, subject

argument, complement

predicaat (+ eerste argument, subject)

argument, complement, eventueel object

argument, complement

hoofd

attribuut (gerundium)

satelliet, adjunct

hoofd

attribuut

attribuut (ingebedde predicatie, niveau 3) 
niveau 3: ingebedde predicatie in ingebedde predicatie

quibus aetas puerilis ad humanitatem informari solet

informari solet

predicaat

aetas puerilis

argument, subject

NOMINALE GROEP

aetas

puerilis

hoofd

quibus

ad humanitatem

attribuut

satelliet, adjunct

satelliet, adjunct

\section{Hoofdstuk 2, Naamvallen}

\section{Oefening 2.1}

1. cuncta: accusativus, object (tweede argument) bij drieplaatsig complet; sua luce: ablativus, complement (derde argument) bij drieplaatsig complet

De zon vult alles met zijn licht.

2. mundum et elegans animal: nominativus, predicaatsnomen bij est De mens is een verfijnd en beschaafd wezen.

3. nobili genere: ablativus, complement (tweede argument) bij tweeplaatsig nati sunt

Zij stammen uit een aanzienlijk geslacht.

4. ego: nominativus, subject (eerste argument) bij tweeplaatsig curem; id: accusativus, complement (tweede argument) of object bij tweeplaatsig curem

Waarom zou ik daarvoor zorgen?

5. ei legioni castrisque: dativus, complement (derde argument) bij drieplaatsig praefecit; ei: dativus, complement of indirect object (derde argument) bij drieplaatsig attribuit

Hij plaatste Quintus Tullius Cicero aan het hoofd van dat legioen en kampement en stelde hem tweehonderd ruiters ter beschikking.

6. quae: accusativus, object (tweede argument) bij tweeplaatsig fugis

NB quae is pronomen relativum met ingesloten antecedent; quae fugis is als geheel subject bij het predicaat tecum sunt.

$\mathrm{Bij} / \mathrm{met}$ jou is datgene waarvoor jij vlucht.

7. saluti: dativus, predicaatsnomen bij fuit (dativus finalis); suis: dativus, complement bij fuit (dubbele dativus constructie)

Kort daarna sneuvelde hij en redde zijn mensen (was de zijnen tot redding). 
8. doli: nominativus, subject (eerste argument) bij tweeplaatsig latuere; fratrem: accusativus, complement (tweede argument) bij tweeplaatsig latuere

Juno's listen bleven niet verborgen voor haar broer.

9. optata harena: ablativus, complement (tweede argument) bij tweeplaatsig potiuntur

De Trojanen gaan van boord en maken zich meester van het vurig begeerde strand.

10. statura humili, corpore exiguo: ablativus, predicaatsnomen (ablativus qualitatis) bij fuit

Agesilaus had een weinig indrukwekkende gestalte en een iel lichaam.

11. munus: accusativus, object (tweede argument) bij drieplaatsig dat; ituris: dativus, indirect object (derde argument) bij drieplaatsig dat

De koning geeft een geschenk aan hen die op het punt staan te vertrekken.

12. te: accusativus, complement (eerste argument) bij tweeplaatsig miseret (onpersoonlijk predicaat); natae en tui: genitivus, complement (tweede argument) bij tweeplaatsig miseret

$\mathrm{O}$ vader, heb jij geen medelijden en met je dochter en met jezelf?

13. leto: ablativus, complement (tweede argument) bij tweeplaatsig gaudete, of satelliet, adjunct (causae) bij eenplaatsig gaudete

Verheug u om de dood van twee personen.

14. mediocris ingeni: genitivus, predicaatsnomen (genitivus qualitatis) bij est

NB moderari orationi is subject bij est

Het getuigt van een niet middelmatig talent om je taalgebruik te matigen.

15. tibi: dativus, complement (tweede argument) bij tweeplaatsig noceret

Wat was ik bang dat het Libische rijk jou enige schade zou toebrengen!

Oefening 2.2

1. cui: dativus, complement bij faveam

Wie zou ik liever begunstigen?

2. Iovem: accusativus, object (tweede argument) bij rogat (munus is het complement en derde argument in een dubbele accusativus constructie)

Zij vraagt Jupiter om een geschenk.

(eventueel: Iovis: genitivus, attribuut bij munus; zij vraagt om het geschenk van Jupiter) 
3. neminem: accusativus, complement bij paenitebit (onpersoonlijk predicaat)

Niemand zal het spijten jou te hebben aangezet tot dit gesprek.

4. tota Gallia: ablativus, complement bij potiri

Orgetorix en Dumnorix hopen dat zij heel Gallia kunnen overmeesteren.

5. Marcellinum nostrum: accusativus, object bij despero

Ik wanhoop nog niet aan onze Marcellinus; hij kan nog steeds gered worden.

6. ingresti Latio: dativus, complement bij intulit

Het overwonnen Griekenland overwon de woeste winnaar en bracht kunsten en wetenschappen (of beschaving) in het boerse Latium.

7. senatui: dativus, complement bij pareamus; bonis: dativus, complement bij consulamus

Laten wij het vaderland liefhebben, de senaat gehoorzamen en zorgen voor loyale mannen.

8. Stoicis: dativus, complement bij placet (onpersoonlijk predicaat; subject: suo $\mathrm{t} / \mathrm{m}$ appellare)

De stoïcijnen willen graag elk ding bij zijn eigen naam noemen.

9. cladium veterum vestrarum, beneficiorum nostrorum: genitivus, complement bij obliti estis

Zijn jullie én jullie oude nederlagen én onze weldaden tegenover jullie vergeten?

10. te: accusativus, object bij subtrahe; aspectu nostro: ablativus, complement bij subtrahe

Blijf staan en mijd mijn blik niet.

\section{Oefening 2.3}

1. ceteros: accusativus, complement bij het onpersoonlijke predicaat pudeat

2. illi: dativus, complement (dativus possessivus) bij erat

3. fatali lege: ablativus, adjunct (causae) bij geruntur

4. virtuti of virtutis: dativus of genitivus, complement op woordgroepniveau bij het adiectivum simile. In de oorspronkelijke tekst staat virtuti.

5. tibi: dativus, complement bij het onpersoonlijke predicaat placebit

6. accusativus en ablativus, object en adjunct (instrumentalis) bij verberat

7. mihi: dativus, complement bij het onpersoonlijke predicaat liceret, of eventueel me, accusativus, subjectsaccusativus in de a.c.i. (infinitivus: dicere). In de oorspronkelijke tekst staat mihi. 
8. peccato en supplicio: ablativi, complement bij respectievelijk drieplaatsig absolvo en drieplaatsig libero

9. horum criminum: genitivus, attribuut bij fundamentum

10. carmine: ablativus, complement op woordgroepniveau bij het adiectivum digna

11. tertio die: ablativus, adjunct (tijdstip) bij refecit

12. me: accusativus, object bij terrent

13. mentis et rationis: genitivus, complement op woordgroepniveau bij het adiectivum particeps

14. mea carmina: accusativus, complement of object bij curas

15. dicto: ablativus, adjunct (comparationis) bij de comparativus citius

16. tres horas: accusativus, adjunct (spatii) bij pugnatum est

17. magno usui: dativus, adjunct (finalis) bij praeparata erat

18. populi Romani: genitivus of populo Romano, dativus, complement op woordgroepniveau bij het adiectivum propria. In de originele tekst staat populi Romani.

19. domi: locativus, adjunct bij est

20. optimum en rectissimum: accusativus en nominativus, optimum: predicaatsnomen in de a.c.i.; rectissimum: predicaatsnomen bij erit

\section{Oefening 2.4}

1. omne hoc tempus: accusativus, object bij transmisi; iucundissima quiete: ablativus, adjunct (modi)

Deze hele tijd heb ik doorgebracht in de aangenaamste rust.

2. duritia: nominativus, subject bij nota est; silicis: genitivus, attribuut bij duritia; nullis en ferientibus: dativus, complement bij nota est

De hardheid van steen is niemand beter bekend dan wie zich daaraan stoten.

3. mens: nominativus, subject bij manet; immota: nominativus, predicaatsnomen bij manet; lacrimae: nominativus, subject bij volvuntur; inanes: nominativus, predicativum (dubbelverbonden bepaling) bij volvuntur

Zijn geest blijft onbeweeglijk, tranen vallen vergeefs.

4. metus: nominativus, subject bij dicitur; hominum: genitivus, attribuut bij metus, genitivus obiectivus en ook subiectivus; hostes: nominativus, subject bij timent \& timentur

'Metus hostium' wordt terecht gezegd zowel wanneer de vijanden vrezen als wanneer zij gevreesd worden. 
5. homines: nominativus, subject bij sunt; quos: accusativus, eerste complement bij de onpersoonlijke predicaten pudeat en taedeat; libidinis en infamiae suae: genitivus, tweede complement bij de onpersoonlijke predicaten pudeat en taedeat

Er zijn mensen die zich niet schamen voor en evenmin gruwen van lust en schande.

6. domi: locativus, adjunct (loci) bij invenio; quemquam: accusativus, object bij invenio; qui: nominativus, subject bij viderit; illum: accusativus, object bij viderit

Noch thuis noch in de stad vind ik iemand die hem heeft gezien.

7. sententia: nominativus, subject bij visa est; atrox: nominativus, predicaatsnomen bij visa est; senatui: dativus, complement bij visa est

De senaat vond de beslissing al te gruwelijk. (De beslissing scheen de senaat al te gruwelijk.)

8. magna fiducia: ablativus, adjunct (modi) bij procedunt; quibus: dativus, complement bij praeerat; D. Brutus: nominativus, subject bij praeerat

Met groot zelfvertrouwen rukken zij op naar onze schepen, waarover Decimus Brutus het commando voerde.

9. proprium: nominativus, predicaatsnomen bij est; stultitiae: genitivus of dativus, complement op woordgroepniveau bij proprium; aliorum: genitivus, attribuut bij vitia; vitia: accusativus, object bij cernere; suorum (sc. vitiorum): genitivus, complement bij oblivisci Het is eigen aan dwaasheid om de fouten van anderen te zien en eigen fouten te vergeten.

10. castra: nominativus, subject bij defendebantur; quae: nominativus, subject bij erant relictae; praesidio: dativus, adjunct (van doel, finalis) bij erant relictae; multo: ablativus (mensurae), adjunct bij comparativus acrius

Het kamp werd door de cohorten, die ter bescherming waren achtergelaten, ijverig verdedigd, zelfs veel feller door de Thracische en uitheemse hulptroepen.

11. Quintia: nominativus, subject bij formosa est; formosa, candida, longa en recta: nominativus, predicaatsnomen bij est; multis en mihi, dativus, adjunct (iudicantis)

Quintia is knap in de ogen van velen, in mijn ogen is zij verblindend, lang en rijzig.

12. decemviris: dativus, indirect object bij nuntiant; omni ope: ablativus, adjunct (instrumentalis) bij contineant; milites: accusativus, object bij contineant

Zij berichten de decemviri dat dezen met elk middel de soldaten moeten afhouden van een opstand. 
13. rumores omnes: accusativus, object bij aestimemus; senum severiorum: genitivus, attribuut bij rumores; unius assis: genitivus, argument (pretii) bij aestimemus

Laten wij leven, Lesbia, en liefhebben en de roddels van strenge oude mannen geen cent waard achten!

14. nemo: nominativus, subject bij est; asperitate ea en immanitate: ablativus qualitatis als predicaatsnomen bij est; naturae: genitivus, attribuut bij immanitate; congressus: accusativus, object bij fugiat atque oderit; hominum: genitivus, attribuut bij congressus Niemand legt zo'n ruwheid en onmenselijkheid van karakter aan de dag dat hij ontmoetingen met mensen mijdt en haat.

15. viri boni: genitivus qualitatis als predicaatsnomen bij est; utilitati en emolumento: dativus finalis als predicaatsnomen bij esse; amicis: dativus, complement bij utilitati (sc. esse); rei publicae: dativus, complement bij emolumento esse

Het is kenmerkend voor een goede man dat hij zijn vrienden tot nut is en de staat tot voordeel.

Oefening 2.5

zin 1

Graecarum artium et disciplinarum: genitivus, of Graecis artibus et disciplinis, ablativus, complement op woordgroepniveau bij het adiectivum plena. In de oorspronkelijke tekst staat de genitivus. eisdem/iisdem/isdem oppidis: ablativus bij in, adjunct (loci)

Romae: locativus, adjunct bij neglegebantur (loci)

rei publicae: genitivus, attribuut bij tranquillitatem

zin 2

civitate en ceteris praemiis: ablativus, derde complement bij donarunt (hunc is object)

cognitione atque hospitio: ablativus, complement op woordgroepniveau bij het adiectivum dignum

zin 3

celebritate: ablativus, samen met hac tanta adjunct bij esset notus (famae: attribuut bij celebritate)

absentibus: dativus, complement op woordgroepniveau bij het adiectivum notus

Romam: accusativus, adjunct van richting bij venit

consule of consulibus: ablativus absolutus, adjunct (tijdsbepaling) bij venit. In de oorspronkelijke tekst staat consule.

zin 4

consules eos: accusativus, object bij nactus est

res gestas: accusativus, object bij adhibere

eum: accusativus, object bij receperunt 
Oefening 2.6

zin 1

sanctos: accusativus-complement bij appellat, congrueert met poetas nobis: dativus-complement bij commendati esse

zin 2

sanctum: nominativus neutrum, predicaatsnomen bij sit, congrueert met het subject nomen

zin 3

voci: dativus-complement bij respondent

cantu: satelliet, ablativus causae bij flectuntur

rebus optimis: ablativus-complement bij het predicativum instituti

zin 4

Homerum: subjectsaccusativus bij civem esse

suum: predicaatsnomen bij esse (a.c.i.)

$\operatorname{zin} 5$

alienum: object bij expetunt

vivum: predicativum bij hunc en repudiamus

noster: predicaatsnomen bij est

zin 6

ipsi illi Gaio Mario: dativus-complement bij het predicaatsnomen iucundus

\section{Hoofdstuk 3, Infinitivus}

Oefening 3.1

1. intermitti: a.c.i. als subject bij nefas est (sollemnia is subjectsaccusativus)

Het is niet toegestaan dat de plechtigheden van de spelen worden onderbroken.

2. dominari: complement bij tweeplaatsig volunt; liberi esse: complement bij tweeplaatsig, uit volunt af te leiden vultis

Zij willen heersen, jullie [willen] vrij zijn.

3. vinci: subject bij turpe est

Het is voor een jonge man schandelijk overwonnen te worden door een oude man.

4. flagitare: infinitivus historicus

Intussen eiste Caesar dagelijks graan van de Haedui.

5. iungere: complement bij drieplaatsig imperat

Titan beveelt de snelle Horae de paarden in te spannen.

6. nominari: a.c.i. als object bij tweeplaatsig legimus (quem is subjectsaccusativus)

Hij, van wie wij lezen dat hij dictator wordt genoemd, werd bij de ouden betiteld als 'magister populi'. 
7. posse: complement bij tweeplaatsig volui; pati: complement bij tweeplaatsig posse; temptasse: a.c.i. als object bij negabo (me is subjectsaccusativus)

Ik wilde het kunnen verdragen en zal niet ontkennen dat ik het heb geprobeerd.

8. capere: complement bij drieplaatsig iussit (milites tweede complement) of a.c.i. als object (milites subjectsaccusativus)

De consul beval de soldaten meteen de wapens te grijpen.

De consul beval dat de soldaten meteen de wapens grepen.

9. accedere: complement bij tweeplaatsig vetiti sunt

Men heeft hun verboden naderbij te komen.

10. civitas prudentissima fuisse: n.c.i., persoonlijk passieve tegenhanger van de a.c.i. prudentissimam civitatem Atheniensium fuisse tradunt

Men levert over dat de stadstaat der Atheners de verstandigste is geweest of

Volgens de overlevering is de stadstaat der Atheners de verstandigste geweest.

\section{Oefening 3.2}

1. tueri: complement bij tweeplaatsig debet Iedereen moet de zijnen/zijn eigen mensen beschermen.

2. vesci: complement bij tweeplaatsig prohibiti erant

Het was de fluitspelers verboden in de tempel van Jupiter te eten.

3. esse: a.c.i. als subject bij eenplaatsig constat

Het staat vast dat Pompeius ons allervriendschappelijkst gezind is.

4. emori en vivere: a.c.i. als object bij tweeplaatsig maluerunt (liberos suos is subjectsaccusativus)

Saguntijnse ouders wilden liever dat hun kinderen stierven dan als slaven leefden.

5. habiturum [esse]: a.c.i. als object bij tweeplaatsig sperabat (sese is subjectsaccusativus)

Hij hoopte dat hij heel spoedig omvangrijke troepen zou hebben.

6. necare: subject bij eenplaatsig licet

Het is niet toegestaan je broer te doden.

7. traducere: complement bij tweeplaatsig conati sunt

Zij probeerden daar een deel van hun troepen over te zetten.

8. fuisse: a.c.i. als object bij docet (Orpheum poetam is subjectsaccusativus)

Aristoteles leert dat de dichter Orpheus nooit heeft bestaan. 
9. fuisse: n.c.i., persoonlijk passieve tegenhanger van de a.c.i. illos homines parum putat/putant cautos fuisse

Die mensen zijn, denkt men/naar men denkt, te weinig voorzichtig geweest.

10. agere: subject bij tweeplaatsig delectat (hoc congrueert met agere; nihil is object bij agere)

Dit niets doen bevalt mij.

\section{Oefening 3.3}

1. occidi: a.c.i. als object bij tweeplaatsig iussit; centuriones is subjectsaccusativus. occidi is geen complement bij drieplaatsig iussit, want centuriones kunnen onmogelijk de recipiënt zijn van iussit occidi: je kunt niet het bevel krijgen omgebracht te worden.

Hij beval dat de centurionen werden omgebracht / de centurionen om te brengen.

2. absolutum iri: a.c.i. als object bij tweeplaatsig sperat; se is subjectsaccusativus (het subject van sperat is de relatieve bijzin met ingesloten antecedent: quem defendis)

Degene die jij verdedigt hoopt dat hij zal worden vrijgesproken.

3. festinare trepidare credere: infinitivi historici

Plotseling maakte somberheid zich meester van allen: ze haastten zich, sidderden, vertrouwden geen plaats of mens echt.

4. temptata esse: n.c.i., persoonlijk passieve tegenhanger van quam temptatam esse scelere isto nefario dicit/dicunt

Die familie die, naar men zegt, is beproefd door die gruwelijke misdaad, is vol rechtschapenheid.

5. iussum esse: a.c.i. als object bij tweeplaatsig dixit; se is subjectsaccusativus; pugnare: complement bij tweeplaatsig iussum esse Agesilaus de Spartaan zei dat hij door een orakel van de goden het bevel had gekregen vanuit de heuvels te vechten.

\section{Oefening 3.4}

\section{zin 2}

infirmari: complement bij tweeplaatsig potest zin 3

esse ascriptum: a.c.i. als object bij tweeplaatsig negabis; de subjectsaccusativus is hunc

zin 4

egisse: a.c.i. als object (evenals de voorafgaande infinitivi opinari, scire, audisse, vidisse en interfuisse) bij tweeplaatsig dicit; de subjectsaccusativus is se

zin 6

interisse: a.c.i. als object bij tweeplaatsig scimus; subjectsaccusativus is quas 
zin 7

dicere: subject bij eenplaatsig est ridiculum

habere: complement bij tweeplaatsig possumus

depravari: complement bij tweeplaatsig possunt

solere: a.c.i. als object bij tweeplaatsig dicis; quas is subjectsaccusativus

corrumpi: complement bij tweeplaatsig solere

desiderare: subject bij eenplaatsig est ridiculum (evenals dicere, quaerere, tacere, flagitare en repudiare)

Oefening 3.5

exortum in zin 1

factum in zin 3

datum in zin 4

Oefening 3.6

zin 2

esse: a.c.i. (samen met stationes vigiliasque) als subject bij placuerat

vocare en referre: complement bij drieplaatsig coegit

zin 3

labare: a.c.i. (samen met animos) als subject bij apparuit

agi: complement bij tweeplaatsig posse

frui: complement bij tweeplaatsig velint

esse: a.c.i. (samen met inritatos, non fractos) als subject bij appareat

$\operatorname{zin} 5$

isse: a.c.i. als subject bij traditum est

flexisse: a.c.i. als subject bij traditum est

\section{Hoofdstuk 4, Participium}

\section{Oefening 4.1}

1. questus: nominativus, predicativum

Na hierover in de vergadering zijn beklag te hebben gedaan, vertrok hij uit de provincie.

2. pervenientia: accusativus, attributief bij verba

Jij brengt woorden terug die mijn oren niet bereiken.

3. moriens: nominativus, predicativum

Hoor wat Epicurus stervend/bij zijn dood zegt.

4. pugnantes: accusativus, a.c.p.

Ik zag stieren vechten voor een sneeuwwit wijfje.

5. exercita: nominativus, predicativum

Maar intussen spreekt Venus, door zorgen verontrust/omdat zij door zorgen gekweld is, Neptunus toe. 
6. amissa: ablativus, dominant in ablativus absolutus met patria, adjunct

Wij zullen worden gedwongen om, na het verlies van ons vaderland/nu we ons vaderland hebben verloren, trotse meesters te gehoorzamen.

7. volentem en nolentem: accusativus, substantivisch

Het lot leidt de willende, (maar) sleept/trekt de niet-willende voort.

8. omisso: ablativus, dominant in ablativus absolutus met bello, adjunct

De koning keerde naar Ephese terug, toen/nadat hij de oorlog die hij was begonnen, had gestaakt.

9. vectus: nominativus, predicativum (van het deponens vehi)

$\mathrm{Na}$ te zijn gevaren via vele volken en over vele zeeën, kom ik, broer, om deze trieste dodenoffers te brengen.

10. dediti en accepti: genitivus, dominant gebruikt, samen met Segestis attribuut bij fama

Het gerucht van de overgave en de welwillende ontvangst van Segestes is wijdverbreid.

\section{Oefening 4.2}

1. arbitratus: nominativus, predicativum

In de mening dat die oorlog snel voltooid kon worden, voerde hij het leger daarheen.

2. audentes: accusativus, substantivisch

Het lot en de godheid helpen degenen die durven.

3. exstructos: accusativus, attributief bij montes

Driemaal heeft de Vader de opeengestapelde bergen met zijn bliksem vernietigd.

4. abdito: ablativus absolutus met ferro, adjunct

$\mathrm{Na}$ het zwaard onder zijn kleed te hebben verborgen, vertrok hij.

5. dicentem: accusativus, a.c.p.

Liever zal ik Laelius horen praten.

6. labentem: accusativus, predicativum bij animum en impulit; labantem is hier proleptisch gebruikt: labi is het gevolg van impellere Hij heeft als enige mijn gevoelens veranderd en mijn hart aan het wankelen gebracht.

7. subactus: nominativus, predicativum

Door vrees gedwongen maakt Remus de zaak openbaar.

8. relicta: ablativus absolutus met Troia, adjunct

Vaak verlangden de Grieken ernaar Troje te verlaten en de vlucht te ondernemen. 
9. surgente: ablativus, dominant in de prepositieverbinding a sole Hij verruilt koopwaar vanaf zonsopgang.

10. transgresso: dativus, predicativum (Hannibali: dativus possessivus)

Hoeveel troepen Hannibal had toen hij overstak naar Italië, daarover bestaat absoluut geen overeenstemming onder de zegslieden.

\section{Oefening 4.3}

1. capta en direpta: dominant gebruikt in voorzetselverbinding met post, congrueren met castra, vertaald met zelfstandige naamwoorden: 'de inname en verwoesting'.

accitus: predicatief bij moverat, congrueert met het subject Hannibal, vertaald met zelfstandige hoofdzin: 'hij was tegen de Hirpini in het geweer geroepen'.

pollicente: attributief gebruikt, congrueert met a Statio Trebio, in de vertaling is een relatieve bijzin gebruikt: 'die hem beloofde Compsa in handen te zullen spelen'.

3. volgatum: dominant gebruikt in voorzetselverbinding met post, congrueert met adventum, vertaald met gesubstantiveerde infinitief: 'het bekend worden'.

4. relictis: ablativus absolutus met praeda omni atque impedimentis (adjunct), vertaald met zelfstandige hoofdzin: 'daar liet hij de totale buit en de legertros achter'.

partito: ablativus absolutus met exercitu (adjunct), vertaald met zelfstandige hoofdzin: 'splitste het leger'.

deficientes en detractantis: attributief, congruerend met het object urbes, in de vertaling weergegeven met relatieve bijzinnen: 'die van de Romeinen afvielen' en 'die dit weigerden'.

5. oppugnaturus: predicativum bij petit, congrueert met het subject ipse (= Hannibal), vertaald met onbepaalde-wijsconstructie: 'om te bestormen'.

6. actam: attributief, congrueert met praedam (object van ostentantes), vertaald met aanvullingsinfinitief: 'voor zich uit te drijven'. ostentantes: predicativum bij obequitare, congrueert met het object alios, in de vertaling uitgedrukt door een bijwoord en bijvoeglijk naamwoord, 'goed zichtbaar', die in het Nederlands predicatief gebruikt zijn.

7. cedentibus: substantivisch gebruikt in voorzetselverbinding met $a b$ (agens), expliciterend vertaald met combinatie van bijvoeglijk naamwoord en zelfstandig naamwoord: 'de terugwijkende tegenstanders'. 
tracta: predicativum bij circumventa est, congrueert met het subject turma, in de vertaling weergegeven met zelfstandige hoofdzin: 'het escadron werd in de hinderlaag getrokken en omsingeld'.

8. conspectae: dominant gebruikt, congrueert met het subject naves, vertaald met zelfstandig naamwoord: 'de aanblik'.

9. cedentes: substantivisch, object bij secutus, expliciterend vertaald met combinatie van bijvoeglijk naamwoord en zelfstandig naamwoord: 'de wijkende vijanden'.

secutus: predicativum bij cecidit, congrueert met het subject Hegeas, vertaald met een bijwoordelijke bijzin: 'toen hij achtervolgde'.

10. conspecta: dominant gebruikt, congrueert met het subject moenia, in de vertaling weergegeven met een zelfstandig naamwoord: 'de aanblik'.

oppugnanti: substantivisch, dativus-complement bij het adjectief prompta, vertaald met infinitiefverbinding: 'om te bestormen'.

\section{Oefening 4.4}

zin 3

missus: predicativum bij alter en fundit fugatque

compulsos: predicativum bij aan te vullen Volscos en bij potitur

persecutus: predicativum bij het subject (alter) en potitur

zin 6

obsidentem: attributief bij exercitum (eventueel predicativum)

clausos: predicativum bij quos en habebat

profectae: attributief bij legiones

zin 7

erumpentium: substantivisch, attribuut bij impetum

patentem: attributief bij portam

facta: ablativus absolutus met caede

arreptum: attributief bij ignem (object bij iniecit)

imminentibus: attributief bij aedificiis (complement bij iniecit)

Oefening 4.5

zin 2

commisso: ablativus absolutus met spectaculo

caesum: predicativum bij servum en egerat

zin 6

obversata: predicativum bij species en visa est

spreti: dominant bij numinis (spreti numinis: attribuut bij mercedem)

zin 8

cunctantem: predicativum bij [eum] en adorta est 
zin 10

fessus: predicativum bij het subject en defertur

praeteritis en instantibus: attributiva bij malis

adhibito: ablativus absolutus met consilio

visa en audita: substantivisch, object bij exposuisset

obversatum: deel van het predicaat in de a.c.i. (als object) bij exposuisset

repraesentatas: deel van het predicaat in de a.c.i. (als object) bij exposuisset

zin 11

captus: predicativum bij het subject en delatus esset

functum: predicativum bij eum en redisse

\section{Hoofdstuk 5, Gerundi(v)um}

\section{Oefening 5.1}

1. vastandi: genitivus, attribuut bij furor

De razernij om andermans zaken te verwoesten dreef de onfortuinlijke Alexander voort.

2. dicendo: ablativus na de prepositie de, adjunct

Wat is dwazer dan spreken over het spreken?

3. navigandi: genitivus, complement bij insuetus

De Haeduer Dumnorix vreesde de zee omdat hij geen ervaring had met varen.

4. flendo: ablativus, adjunct

De nacht verstrijkt, Aeneas, wij verdoen onze uren met huilen.

5. audiendum: accusativus na de prepositie ad, adjunct

Hij kon woorden gebruiken die aangenaam waren om aan te horen.

6. veniendi: genitivus, attribuut bij causa

Hij vroeg wat de reden was van zijn komst.

7. legendo: ablativus na de prepositie in, adjunct; scribendi, genitivus, attribuut bij otium

Deze tijd werd helemaal besteed aan lezen, er was geen tijd om te schrijven.

Oefening 5.2

1. dicenda: nominativus, congrueert met fuga, predicaatsnomen $\mathrm{Nu}$ moet ik de vlucht van de koning vermelden.

2. immolandorum: genitivus, congrueert met hominum, dominant gebruikt in gerundivumconstructie, als geheel attribuut bij consuetudinem 
Wie weet immers niet dat zij tot op de dag van vandaag die gruwelijke en barbaarse gewoonte behouden om mensen te offeren?

3. emendis: ablativus, congrueert met iuvencis, dominant gebruikt in gerundivumconstructie na prepositie in, adjunct

De boer moet bij het kopen van jonge stieren vaste voorschriften volgen.

4. petendae genitivus, congrueert met pacis, dominant gebruikt in gerundivumconstructie afhankelijk van de postpositie causa, adjunct

De Menapiërs sturen gezanten naar hem om vrede te vragen.

5. tollenda: ablativus, congrueert met superstitione, dominant gebruikt in gerundivumconstructie, adjunct

Door het vernietigen van bijgeloof wordt godsdienst niet vernietigd.

6. dolendum: nominativus neutrum, predicaatsnomen (onpersoonlijk)

Als je wil dat ik huil, moet jij eerst zelf verdriet hebben.

7. gerendo: dativus, congrueert met bello, dominant gebruikt in gerundivumconstructie, complement

Jij gaf Marcus Cato de verantwoordelijkheid om oorlog te voeren.

\section{Oefening 5.3}

1. accommodanda: gerundivum, nominativus, congrueert met het subject oratio, predicaatsnomen

Onze redevoering moet worden aangepast aan de oren van de massa.

2. largiendo: gerundium, ablativus, adjunct

Velen verkwistten hun erfdeel door het ondoordacht uit te delen.

3. superanda: gerundivum, nominativus, congrueert met het subject fortuna, predicaatsnomen

ferendo: gerundium, ablativus, adjunct

Wat het ook zal zijn, elk lot kan overwonnen worden door het te dragen.

4. navigandum: gerundium na prepositie $a d$, adjunct of complement bij idoneam

$\mathrm{Na}$ gunstig weer te hebben gekregen om te varen lichtte hij omstreeks de derde wacht het anker.

5. premendae: gerundivum, genitivus, congrueert met plebis, dominant gebruikt in gerundivumconstructie, attribuut bij tempus Velen meenden dat de tijd was gekomen om het volk te onderdrukken. 
6. utendum: gerundivum, nominativus neutrum, predicaatsnomen (onpersoonlijk), utendum is verbonden met complement in ablativus: consilio

Men moet het meest gebruikmaken van de raad van vrienden.

7. precando: gerundium, ablativus, adjunct

Jij bent zijn vrouw, jij mag zijn hart met smeekbeden vermurwen.

8. novandi: gerundium, genitivus, attribuut bij het subject occasio

Er is gelegenheid geboden om zaken te vernieuwen.

9. transportandum: gerundivum, accusativus na de prepositie ad, congrueert met exercitum, dominant gebruikt in gerundivumconstructie, adjunct

Zij beloofden een grote hoeveelheid schepen voor het vervoer van het leger.

10. faciendae: gerundivum, genitivus, congrueert met lanae, dominant gebruikt in gerundivumconstructie, attribuut bij het subject fama

Door jou mag onder de stervelingen de hoogste reputatie in de weefkunst worden nagestreefd.

11. gerundum: gerundivum, accusativus, congrueert met het object bellum, predicativum

Het Romeinse volk liet liever de consul Crassus oorlog voeren dan de ambteloze Africanus.

12. reducendum: gerundivum, accusativus, congrueert met het object perfugam, aanvullingsgerundivum (complement)

Fabricius liet de overloper terugbrengen naar Pyrrhus.

Oefening 5.4

zin 1

expetendum: gerundivum als predicaatsnomen in a.c.i., congrueert met nihil

persequenda: gerundivum, dominant gebruikt bij in ea, prepositieverbinding (adjunct) in de ablativus

ducenda: gerundivum als predicaatsnomen in de a.c.i., congrueert met pericula

zin 3

intuendum en imitandum: gerundium in prepositieverbinding met ad, adjunct bij reliquerunt

zin 4

administranda: gerundivum, dominant gebruikt bij de prepositieverbinding (adjunct) in re publica 


\section{Hoofdstuk 6, Tempus}

\section{Oefening 6.1}

De uitgangssituatie wordt in deze fabel aangegeven door het plusquamperfectum venerant (r. 1) en het imperfectum stabat (r. 2); venerant is voortijdig aan stabat (oriëntatiepunt in het verleden). Binnen deze achtergrondsituatie vindt een aantal opeenvolgende incidenten plaats die het verhaal verder brengen. Deze incidenten vormen de voorgrond van het verhaal en staan in het perfectum en praesens:

- intulit (r. 4), perfectum, eerste incident, het verhaal komt op gang (cf. tunc!)

- inquit (r. 5), perfectum of praesens, de tweede stap in het verhaal

- ait (r. 10), praesens, nieuwe poging van de wolf om ruzie te maken

- respondit (r. 11), perfectum, reactie van het lam (de eerste reactie van het lam is niet met een narratief verbum dicendi gegeven, wel staat er het bijwoord contra (r. 6))

- inquit (r. 12), perfectum (of praesens), derde poging van de wolf tot ruzie

- lacerat (r. 13), praesens, narratief hoogtepunt Het laatste perfectum, scripta est (r. 14), behoort niet meer tot het verhaal, maar is auteurscommentaar en vormt de traditionele afsluiting van de fabel.

Oefening 6.2

zin 1

erat: imperfectum: schildering van de uitgangssituatie

essent: coniunctivus imperfectum: subjectieve reden; uitgangssituatie

\section{zin 2}

misit: perfectum, begin van het verhaal (cf. tum), eerste actie om het dreigende gevaar af te wenden

zin 3

audita est: perfectum, de tweede fase van het verhaal

spernebant en metuebant: imperfectum, achtergrondinformatie, toelichting op het afwijzend gedrag van de naburige stammen zin 4

passa est: perfectum, de derde fase van het verhaal 


\section{Hoofdstuk 7, Modus}

Oefening 7.1

1. imperatief zinstype, adhortativus

Laten wij het vaderland liefhebben, de senaat gehoorzamen en zorgen voor loyale burgers!

2. imperatief zinstype, prohibitivus

Laat deze brief je niet van streek maken

3. interrogatief zinstype, dubitativus, verleden

Wat moest ik doen?

4. declaratief zinstype, potentialis, heden (fortasse: voorzichtige bewering)

Misschien zul jij ook willen weten wat het lot van Priamus is geweest.

5. interrogatief zinstype, potentialis

Waar zul je iemand kunnen vinden die de eer van zijn vriend stelt boven zijn eigen eer?

6. declaratief zinstype, irrealis, verleden

Als Catilina tot deze dag in de stad was gebleven, dan hadden wij met hem moeten strijden.

7. imperatief zinstype, concessivus (NB sane in de eerste hoofdzin, certe in de tweede)

Laat deze zaken maar onjuist zijn/deze zaken mogen onjuist zijn, verwerpelijk zijn ze zeker niet.

8. declaratief zinstype, potentialis, heden

Door het gebruik van de coniunctivus wordt de op zich nogal stellige bewering (sine ulla dubitatione) wat afgezwakt.

Dit zou ik zonder enige twijfel kunnen bevestigen.

9. imperatief zinstype, adhortativus

Maar laten wij naar de zaak terugkeren!

10. imperatief zinstype, optativus (niet beheersbaar, vervulbaar geachte wens)

Moge de aarde licht voor jou zijn.

11. interrogatief zinstype, dubitativus, heden

Zal/Moet ik klagen of zwijgen?

12. imperatief zinstype, adhortativus

Deze manier bevalt mij: laat het leven evenwichtig worden geleid tussen goede zeden en publieke; laten allen opkijken naar ons leven, maar het wel waarderen.

13. declaratief zinstype, irrealis, verleden

Met de tijd groeide hun liefde; ze zouden ook rechtmatig gehuwd zijn, maar hun vaders verboden dat. 


\section{4. imperatief zinstype, concessivus}

Laat hij een dief zijn, een heiligschenner, een kampioen in alle schanddaden en misdrijven; maar hij is toch een goede leider.

\section{Oefening 7.2}

1. tenderet: coniunctivus imperfectum in declaratieve zin, irrealis van het heden

2. dicam: coniunctivus praesens in interrogatieve zin, deliberativus

3. agamus: coniunctivus praesens in imperatieve zin, adhortativus

4. fuissemus: coniunctivus plusquamperfectum in imperatieve zin, optativus, onvervulbare wens die betrekking heeft op het verleden

5. requiram: coniunctivus praesens in interrogatieve zin, deliberativus

\section{Oefening 7.3}

1. detur: coniunctivus in door $u t$ ingeleide argument-bijzin na verbum postulandi

Zij eisen dat er een teken wordt gegeven.

2. posset: coniunctivus in door cum ingeleide satelliet-bijzin, concessivus

Hoewel Socrates gemakkelijk uit de gevangenis kon worden weggevoerd, wilde hij niet.

3. confligeret: coniunctivus in door ne ingeleide satelliet-bijzin, finalis

Om niet met twee legers tegelijk slaags te raken, brak Hannibal het kamp 's nachts op vanuit het gebied rond Tarente.

4. adiuvet: coniunctivus in door quaere ingeleide argument-bijzin, afhankelijke vraagzin

Vraag jij waarom jou die vlucht niet baat?

5. posuerunt: indicativus in satelliet-bijzin, cum temporale (NB tum in de hoofdzin)

Dan immers beginnen onze aanvoerders oorlog te voeren, wanneer zij de voortekens hebben geraadpleegd.

6. consideremus: coniunctivus in door $u t$ ingeleide argument-bijzin (subjectszin) na werkwoord van gebeuren met $u t$

sit: coniunctivus in door qualis ingeleide argument-bijzin (objectszin), afhankelijke vraagzin

Rest ons na te gaan wat de natuur van de goden is.

7. tetigissent: coniunctivus in conditionele door si ingeleide satelliet-bijzin, irrealis van het verleden

Gelukkig, ach al te gelukkig zou ik zijn geweest, als de Trojaanse schepen nooit onze kusten hadden bereikt. 
8. posset: coniunctivus in door cum ingeleide satelliet-bijzin, temporeel of causaal

Toen/omdat Aebutius geen wapen kon vasthouden, verliet hij de strijd.

9. interficiant: coniunctivus in door ne ingeleide argument-bijzin na verbum impediendi

Hij verbood allen om iemand te doden.

10. vidisti: indicativus in feitelijke, door quod ingeleide argument-bijzin na uitdrukkingen die een oordeel uitspreken over de inhoud van de bijzin

Het komt heel slecht uit dat jij hem nergens hebt gezien.

11. ait: indicativus in comparatieve door $u t$ ingeleide satelliet-bijzin Geen enkel ding behalve een lichaam/een materieel ding kan aanraken en aangeraakt worden, zoals Lucretius zegt.

12. possit: coniunctivus in door $u t$ ingeleide satelliet-bijzin, consecutivus (NB ita in hoofdzin)

Verres heeft Sicilië drie jaar lang zo geplunderd dat het op geen enkele manier in zijn oude staat kan worden hersteld.

13. viderim: coniunctivus in relatieve bijzin, consecutief of causaal te interpreteren

Wat ben ik blind (om)dat ik dat niet eerder heb gezien!

(NB me caecum: exclamatieve accusativus)

14. fierent: coniunctivus in door ne ingeleide argument-bijzin na verbum timendi

Vervolgens bekroop angst de senatoren dat er weer geheime samenkomsten en samenzweringen zouden plaatsvinden.

15. luderet: coniunctivus in conditionele door si ingeleide satellietbijzin, irrealis van het heden

Als een Aeneasje, die althans van gezicht sprekend op jou zou lijken, in mijn paleis zou spelen, zou ik mij niet helemaal verlaten en eenzaam voelen.

16. attingas: coniunctivus in door ne ingeleide argument-bijzin na verbum curandi

sapis: indicativus in door si ingeleide conditionele satelliet-bijzin Als je goed bij je verstand bent, zul je je ervoor hoeden mij aan te raken.

17. resolveret: coniunctivus in relatieve bijzin, finaal te interpreteren Toen stuurde de almachtige Iuno, vol medelijden met haar (= Dido's) langdurige pijn en moeilijke dood, Iris van de Olympus naar beneden om haar worstelende ziel uit de knellende ledematen te verlossen. 
18. patiatur: coniunctivus in relatieve bijzin, consecutief te interpreteren

Niemand immers heeft zo'n afkeer van de Muzen dat hij niet gemakkelijk toestaat dat een eeuwig loflied van zijn werken aan poëzie wordt toevertrouwd.

19. destruat: coniunctivus in temporele door dum ingeleide satellietbijzin

Waarom aarzel ik nog? Soms totdat mijn broer Pygmalion mijn muren vernietigt?

20. curent: coniunctivus in door $u t$ ingeleide argument-bijzin na verbum postulandi

De senaat besluit dat de consuls een zo fraai mogelijk gedenkteken moeten laten aanbesteden en oprichten.

NB locandum en faciendum zijn aanvullingsgerundiva

\section{Oefening 7.4}

zin 1

repudiamus: coniunctivus potentialis in retorische vraag (er wordt een ontkennend antwoord verwacht)

contulerit: coniunctivus in concessieve door cum ingeleide satellietbijzin

zin 3

patiatur: coniunctivus in relatieve bijzin, consecutief te interpreteren zin 4

quaereretur: coniunctivus in temporele door cum ingeleide satellietbijzin

audiret: coniunctivus in argumentbijzin, afhankelijke vraagzin; quod en cuius zijn relatief gebruikte vraagwoorden

praedicaretur: coniunctivus in relatieve bijzin, definitivus (in oratio obliqua; en om die reden ook al coniunctivus)

zin 5

gesserat: indicativus in relatieve bijzin

Oefening 7.5

zin 2

commoveretur: coniunctivus imperfectum in consecutieve ut-bijzin (tam in hoofdzin)

esset: coniunctivus imperfectum in concessieve cum-bijzin (tamen in hoofdzin)

zin 4

scripsisset: coniunctivus plusquamperfectum in concessieve cum-bijzin 
$\operatorname{zin} 5$

perveniret: coniunctivus in consecutieve $u t$-bijzin (sic in hoofdzin) zin 6

diligam, admirer, putem: coniunctivus praesens; coniunctivus potentialis in retorische vraag

Oefening 7.6

zin 1

daretur: coniunctivus imperfectum in door quanti ingeleide afhankelijke vraag

zin 3

reddant: coniunctivus praesens in imperatieve zin: adhortativus zin 5

patiar: coniunctivus praesens in interrogatieve zin: deliberativus zin 6

feram: coniunctivus praesens in interrogatieve zin: deliberativus zin 7

secedat, avocet: coniunctivus praesens in imperatieve zin: adhortativus

rapiant: coniunctivus praesens in imperatieve zin: adhortativus zin 8

fruantur: coniunctivus praesens in imperatieve zin: adhortativus

Oefening 7.7

zin 2

fuerit: coniunctivus perfectum in afhankelijke, tweeledige vraag, voortijdig aan invenio

irent: coniunctivus imperfectum in door $u t$ ingeleide argument-bijzin (object) bij pervicere

defenderent: coniunctivus imperfectum in door $u$ ingeleide argumentbijzin (object), bij pervicere

zin 5

sciam: coniunctivus praesens in door $u$ ingeleide argument-bijzin (object) bij sine

venerim: coniunctivus perfectum in afhankelijke vraagzin, voortijdig t.o.v. sciam

sim: coniunctivus praesens in afhankelijke, tweeledige vraagzin, gelijktijdig t.o.v. sciam

zin 6

viderem: coniunctivus imperfectum in finale $u t$-zin (NB in de hoofdzin staat in hoc) 


\section{Hoofdstuk 8, Vraagzinnen}

\section{Oefening 8.1}

1. woordvraag: quis, est

2. quis, esset (coniunctivus in afhankelijke vraag, gelijktijdig met perfectum quaesivit)

quid, vellet (coniunctivus in afhankelijke vraag, gelijktijdig met perfectum quaesivit)

3. quam, habeant (coniunctivus in afhankelijke vraag, gelijktijdig met futurum interrogabo)

4. zinsvraag, nonne (het verwachte antwoord is positief)

5. quo, vertam (coniunctivus in afhankelijke vraag, gelijktijdig met praesens nescio)

6. utrum, an, valeret (coniunctivus in meerledige, afhankelijke vraag, gelijktijdig met perfectum requisivit); ne ... an zou ook mogelijk zijn

7. zinsvraag: num (uit nemo blijkt dat een negatief antwoord wordt verwacht), requirit

8. ne (enclitisch), regatur (coniunctivus in afhankelijke vraagzin, gelijktijdig met praesens videamus); num zou ook kunnen, maar dan heb je tweemaal een woord dat eindigt op -um: num en deorum

9. utrum, an, sit (coniunctivus in meerledige afhankelijke vraagzin, gelijktijdig met praesens deliberandum est); ne ... an zou ook mogelijk zijn

10. zinsvraag: nonne (het verwachte antwoord is positief)

\section{Oefening 8.2}

1. quis, quis, nesciat (coniunctivus potentialis); het is een retorische vraag

2. eloquar an sileam? (coniunctivus deliberativus)

3. -ne, neutrale zinsvraag quorum, consederis (coniunctivus in van venit in mentem afhankelijke vraag, voortijdig aan het praesens venit)

4. quibus, venisset (coniunctivus in van rogitans afhankelijke vraagzin, voortijdig aan verleden (bibebat))

\section{Hoofdstuk 9, Oratio obliqua}

\section{Oefening 9.1}

1. centurio dixit illos/eos fortiter pugnavisse/pugnasse.

De centurion zei dat zij dapper hadden gestreden. 
2. Caesar exclamavit ut legatos ad se mitterent/mittant.

Caesar riep uit dat zij gezanten naar hem moesten sturen.

3. Pompeius respondit ne dubitarent/dubitent pugnare.

Pompeius antwoordde dat zij niet moesten aarzelen te strijden.

4. praetor dixit se, postquam Romam venisset/venerit, consulatum petivisse/petisse.

De praetor zei dat hij, nadat hij naar Rome was gekomen, naar het consulaat had gedongen.

5. rex narravit legatos ipsi (sibi zou verwarring kunnen veroorzaken; of sibi ipsi) liberisque vitam petivisse/petisse.

De koning vertelde dat de gezanten voor hem en zijn kinderen om het leven hadden gesmeekt.

6. philosophus rogavit quid esse turpius quam patriam prodere? Een retorische vraag wordt in indirecte rede een a.c.i.

De filosoof vroeg wat schandelijker was dan het vaderland te verraden.

7. Cicero scripsit iam diu inter Romanos Saguntinosque amicitiam esse; cuius neutros ad id tempus paenitere.

Cicero schreef dat er al lang tussen Romeinen en Saguntijnen een vriendschapsband bestond, en dat geen van beide partijen tot heden er berouw over had.

8. mater rogavit cur mentitus esset.

Moeder vroeg waarom hij had gelogen.

9. Octavianus rogavit ubi castra poneret.

Octavianus vroeg waar hij het kamp moest opzetten.

10. servi rogaverunt num oblivisci possent iniuriarum illorum/eorum.

De slaven vroegen of zij hun onrecht konden vergeten.

Oefening 9.2

ORATIO OBLIQUA

scire se (of: se scire) illa esse vera, neque quemquam ex eo plus quam se doloris capere, propterea quod, cum ipse gratia plurimum domi atque in reliqua Gallia posset, ille minimum propter adulescentiam, per se crevisset, quibus opibus ac nervis non solum ad minuendam gratiam sed paene ad perniciem suam uteretur. se(se) tamen et amore fraterno et existimatione vulgi commoveri. quod si quid ei a Caesare gravius accidisset, cum ipse eum locum amicitiae apud eum teneret, neminem existimaturum (esse) non sua voluntate factum (esse); qua ex re futurum (esse), uti totius Galliae animi a se averterentur. 


\section{TOELICHTING}

a.c.i.: scire se illa esse vera, neque quemquam ex eo plus quam se doloris capere,

(bijzin in or. obliqua) propterea quod, cum (bijzin in bijzin) ipse gratia plurimum domi atque in reliqua Gallia posset, ille minimum propter adulescentiam (sc. posset), per se crevisset, (relatieve bijzin in or. obliqua) quibus opibus ac nervis non solum ad minuendam gratiam sed paene ad perniciem suam uteretur.

a.c.i.: se(se) tamen et amore fraterno et existimatione vulgi commoveri.

a.c.i.: quod ...

(bijzin in oratio obliqua) si quid ei a Caesare gravius accidisset, cum (bijzin in bijzin) ipse eum locum amicitiae apud eum teneret, vervolg a.c.i.: neminem existimaturum (esse) non sua voluntate factum (esse);

a.c.i.: qua ex re futurum (esse),

(bijzin in oratio obliqua) uti totius Galliae animi a se averterentur.

\section{Hoofdstuk 10, Tekstsamenhang}

Oefening 10

1. In $\S 2$ is sprake van een voorgrond-achtergrondstructuur, gesignaleerd door de afwisseling van twee typische achtergrondtijden (het plusquamperfectum haeserat en het imperfectum spatiabatur) met twee voorgrondtijden (het praesens historicum offertur en het perfectum dixit). Het praesens historicum offertur vormt duidelijk het dramatische hoogtepunt van deze episode en wordt gepresenteerd alsof de stand van zaken zich voltrekt voor het oog van de verteller (suggestie van gelijktijdigheid van actie en vertelmoment). De zin facta sunt omnia (perfectum) bevat niet het verslag van de feitelijke voltrekking van de door de geestverschijning voorspelde gebeurtenissen, maar moet eerder gezien worden als een samenvattende constatering achteraf (merk op dat zowel omnis als facere woorden zijn met een algemene, weinig specifieke semantische lading). Een praesens historicum zou hierdoor minder goed passen.

2. De serie imperfecta in $\S 5-6$ (erat, reddebatur, adparebat, gerebat quatiebatque, vigilabantur, sequebatur, inerrabat, erat, proscribebatur) vormt als geheel een beschrijving van een situatie die gedurende langere tijd in de vertelde wereld geldig was en die gekenmerkt wordt door een aantal gebeurtenissen die zich herhaald in deze 
wereld voordeden. Deze door het imperfectum gekenmerkte beschrijving vormt de achtergrond waartegen zich vanaf $\S 7$ het feitelijke verhaal zal gaan afspelen. De overgang van achtergrond (de voorgeschiedenis) naar voorgrond blijkt expliciet door een verandering in de gebruikte tijden: na de serie spanningwekkende imperfecta vormt venit het eerste incident dat een verandering teweegbrengt in de achtergrondsituatie, waarna het verhaal zich verder chronologisch ontwikkelt in een lange serie van historische praesentia, afgewisseld door een enkele infinitivus historicus.

3. De enige niet-ambigue perfectumvorm in de tweede narratieve episode is het laatste woord caruit. Met dit woord brengt Plinius de lezer als het ware geleidelijk terug van de narratieve episode (grotendeels in narratieve praesentia verteld, alsof de verteller en lezer zelf bij de gebeurtenissen aanwezig zijn) naar het overkoepelende argumentatief-betogende raamwerk van de brief als geheel, dat in de eropvolgende overgangszin weer aan de oppervlakte treedt (et haec quidem adfirmantibus credo; illud adfirmare aliis possum). De situatie waarnaar caruit verwijst is blijkens postea een constatering achteraf. Dergelijke 'epilogische' uitspraken lijken incompatibel met het gebruik van het praesens historicum, dat immers de suggestie van een ooggetuigenverslag en een vertelling 'van binnenuit' het verhaal oproept.

4. In de eerste zin van $\S 5$ staat de persoonsvorm voorop en neemt het subject de laatste positie in. Deze volgorde kan worden verklaard door een sterk focale status van het subject, dat in deze zin als een geheel nieuwe en voor het verhaal zeer belangrijke referent wordt geïntroduceerd. Eenzelfde volgorde treffen we aan in de eerste zin van $\S 7$ (venit Athenas philosophus Athenodorus), waarin de hoofdrolspeler Athenodorus wordt geïntroduceerd.

5. In $\S 8$ wordt het anaforisch pronomen ille gebruikt om aan te geven dat er een wisseling van topic is waarbij de aandacht verschuift van de ene reeds bekende referent in het verhaal (het spook) naar de andere (Athenodorus). 



\section{Overzicht van geciteerde auteurs en werken}

Caes. $\quad$ C. Iulius Caesar (c. $100-44)$

Civ. de Bello Civili ('De burgeroorlog')

Gal. de Bello Gallico ('De Gallische oorlog')

Catul. G. Valerius Catullus (c. $84-$ c. 54), auteur van lyrische gedichten: Carmina

Cic. $\quad$ M. Tullius Cicero (106 - 43), auteur van redevoeringen, filosofische en retorische traktaten (pro geeft aan: Redevoering ter verdediging van; in: Redevoering tegen)

Acad. Academica ('De opvattingen van de Academie'), filosofisch geschrift over kennisleer

Amic. de Amicitia ('De vriendschap'), filosofische dialoog Arch. pro Archia

Brut. Brutus, overzicht in dialoogvorm van de Romeinse welsprekendheid

Cael. pro Caelio

Catil. in Catilinam

de Orat. de Oratore ('De redenaar'), dialoog over retorica

Div. de Divinatione ('Voorspellingskunst'), filosofische dialoog

Dom. de Domo sua, redevoering 'Over zijn huis' waarin Cicero de onteigening van zijn grondstuk bestrijdt

Fam. Epistulae ad Familiares ('Brieven aan vrienden en bekenden')

Fin. de Finibus Bonorum et Malorum ('De grenzen van goed en kwaad'), filosofische dialoog over verschillende opvattingen aangaande ethiek

Font. pro Fonteio

Lig. pro Ligario

N.D. de Natura Deorum ('Het wezen der goden'), filosofische dialoog 
Off. de Officiis ('De plichten'), filosofisch testament voor zijn zoon

Parad. Paradoxa Stoicorum ('Stoische paradoxen'), traktaat over retorica

Phil. Philippicae ('Philippische redevoeringen'), gericht tegen Marcus Antonius

Quinct. pro Quinctio

Q.Fr. Epistulae ad Quintum Fratrem ('Brieven aan broer Quintus')

Rep. de Republica ('De staat'), filosofische dialoog over de ideale staatsman en staatsvorm

S. Rosc. pro S. Roscio Amerino

Sest. pro Sestio

Sull. pro Sulla

Tusc. Tusculanae Disputationes ('Gesprekken in Tusculum'), dialoog over ethiek

Ver. $\quad$ in Verrem

Col. L. Iunius Moderatus Columella (eerste eeuw na Chr.), auteur van geschrift over de landbouw: de Re Rustica

Front. Sex. Iulius Frontinus (c. $30-104)$

Str. Strategemata (strategisch overzichtswerk voor militaire commandant)

Gel. Aulus Gellius (123 - c. 165), auteur van Noctes Atticae ('Attische nachten'), over verschillende gebieden van de wetenschap

Hor. Quintus Horatius Flaccus (65 - 8), dichter

A.P. $\quad$ Ars Poetica ('Verhandeling over de dichtkunst')

Ep. Epistulae ('Brieven')

S. Sermones ('Satiren')

Liv. T. Livius (?59 voor Chr. -17 na Chr.), auteur van het geschiedwerk ab Urbe Condita ('Vanaf de stichting van de stad')

Mart. $\quad$ M. Valerius Martialis (tweede helft eerste eeuw na Chr.), auteur van korte gedichten: Epigrammata 
Nep. Cornelius Nepos (c. 99 - 24)

Ag. Agesilaus, biografie van deze koning van Sparta

Ov. P. Ovidius Naso (43 voor Chr. - ?17 na Chr.), dichter Am. Amores ('Liefdeszangen')

Fast. Fasti ('De kalender'), leerdicht over Romeinse feesten en gebruiken

Met. Metamorphoses ('Gedaantenwisselingen'), mythologisch epos

Tr. Tristia ('Treurzangen'), dichterlijke brieven aan vrienden en kennissen

Pl. T. Maccius Plautus († 184 voor Chr.), komediedichter

Am. Amphitruo (genoemd naar een Thebaanse veldheer)

As. Asinaria ('Een ezelverhaal')

Mer. $\quad$ Mercator ('De koopman')

Poen. Poenulus ('De kleine Carthager')

Truc. Truculentus ('Knorrepot')

Plin.

C. Plinius Secundus (c. 61 - 114, Plinius Minor)

Ep. Epistulae, collectie brieven

Sal. C. Sallustius Crispus (86 - c. 34)

Cat. Catilina, monografie over de samenzwering van Catilina

Jug. Jugurtha, monografie over de oorlog met de Numidische koning Jugurtha

Sen. L. Annaeus Seneca (geboren c. 55 voor Chr., Seneca Maior)

Con. Controversiae, fictieve pleidooien voor het gerecht

Sen. L. Annaeus Seneca (c. 5 voor Chr. - 65 na Chr.)

Ep. Epistulae, brieven over ethische kwesties, gericht tot zijn vriend Lucilius

Nat. Naturales Quaestiones, traktaat over natuurfilosofische onderwerpen

Vita Beata De Vita Beata ('Het gelukkige leven'), filosofisch traktaat 
Tac. Cornelius Tacitus (geboren c. 55 na Chr.)

Ann. Annales, geschiedwerk over de Romeinse keizertijd vanaf de dood van Augustus tot de dood van Nero

Dial. Dialogus de Oratoribus ('Dialoog over de redenaars'), over de oorzaken van het verval van de welsprekendheid

Hist. Historiae, geschiedwerk over de Romeinse keizertijd van Galba tot aan de dood van Domitianus

V. Max. Valerius Maximus (eerste helft eerste eeuw na Chr.) auteur van Facta et Dicta Memorabilia, ('Gedenkwaardige daden en uitspraken'), exemplarische verhalen uit de Griekse en Romeinse geschiedenis

Verg. P. Vergilius Maro (70 - 19), dichter

Ecl. Eclogae (of Bucolica, 'Herderszangen')

G. Georgica ('Landleven'), leerdicht over het boerenbedrijf

A. Aeneis, epos over de lotgevallen van de held Aeneas 